\title{
EVAPOTRANSPIRAÇÃO DO CAPIM TANZÂNIA (Panicum maximum Jacq.) E GRAMA BATATAIS (Paspalum notatum flugge) UTILIZANDO O MÉTODO DO BALANÇO DE ENERGIA E LISÍMETRO DE PESAGEM
}

\section{LEONARDO DUARTE BATISTA DA SILVA}

Tese apresentada à Escola Superior de Agricultura "Luiz de Queiroz", Universidade de São Paulo, para obtenção do título de Doutor em Agronomia, Área de Concentração: Irrigação e Drenagem

PIRACICABA

Estado de São Paulo - Brasil

Fevereiro - 2003 


\title{
EVAPOTRANSPIRAÇÃO DO CAPIM TANZÂNIA (Panicum \\ maximum Jacq.) E GRAMA BATATAIS (Paspalum notatum flugge) \\ UTILIZANDO O MÉTODO DO BALANÇO DE ENERGIA E LISÍMETRO \\ DE PESAGEM
}

\section{LEONARDO DUARTE BATISTA DA SILVA \\ Engenheiro Agrícola}

\author{
Orientador: Prof. Dr. Marcos Vinícius Folegatti \\ Co-orientador: Prof. Dr. Nilson Augusto Villa Nova
}

Tese apresentada à Escola Superior de Agricultura

"Luiz de Queiroz", Universidade de São Paulo, para obtenção do título de Doutor em Agronomia, Área de Concentração: Irrigação e Drenagem

PIRACICABA

Estado de São Paulo - Brasil

Fevereiro - 2003 


\section{Dados Internacionais de Catalogação na Publicação (CIP)}

DIVISÃO DE BIBLIOTECA E DOCUMENTAÇÃO - ESALQ/USP

Silva, Leonardo Duarte Batista da

Evapotranspiração do ca pim Tanzânia (Panic um maximumJacq.) e grama batata is (Paspa lum nota tum flugge) utilizando o método do balanço de energia e lisímetro de pesagem / Leonardo Duarte Batista da Silva. - - Piracicaba, 2003.

$93 \mathrm{p}$.

Tese (doutorado) - Escola Superior de Agricultura Luiz de Queiroz, 2003. Bibliografia.

1. Ba lanço de energia 2. Capim tanzânia 3. Eva potranspiração 4. Grama - bata-ta is 5. Lisímetro I. Título

CDD 633.2

"Permitida a cópia total ou parcial deste documento, desde que citada a fonte - $\mathrm{O}$ autor" 
A Deus

Aos meus pais,

\section{Ubiratan Batista da Silva e \\ Rosa Maria Duarte da Silva.}

A meu irmão

Rodrigo Duarte Batista da Silva.

Aos meus avós

Amélia Tancredo Duarte (in memorian),

Geraldo dos Santos Duarte (in memorian),

Isaura Sena da Silva e

Luis Batista da Silva (in memorian).

À minha esposa

Glenda Ribeiro de Oliveira. 


\section{AGRADECIMENTOS}

À Escola Superior de Agricultura "Luiz de Queiroz", da Universidade de São Paulo, especialmente ao Departamento de Engenharia Rural pelo apoio oferecido à realização deste trabalho.

Ao professor Dr. Marcos Vinícius Folegatti, pela confiança, apoio, orientação e especialmente pela amizade. Ao professor Dr. Nilson Augusto Villa Nova, pela amizade e orientação. Aos demais professores do Departamento de Engenharia Rural e Ciências Exatas, em especial aos professores Dr. Ségio Nascimento Duarte e Dr. Paulo César Sentelhas, pelos ensinamentos proferidos e sobretudo pela amizade.

Aos professores da Universidade Federal Rural do Rio de Janeiro, Dr. Daniel Fonseca de Carvalho, Dr. Jorge Luis Pimenta Mello e Dr. Mauro Antonio Homem Antunes pelo apoio. Aos professores da Universidade Federal de Viçosa, Dr. Everardo Chartuni Mantovani e Dr. Fernando Falco Pruski, pela amizade e orientação.

Ao curso de Pós-Graduação em Irrigação e Drenagem da ESALQ/USP, pela oportunidade de fazer parte dessa equipe. À Fundação de Amparo à Pesquisa do Estado de São Paulo (FAPESP), pela bolsa e apoio financeiro para a realização deste trabalho.

Aos funcionários do Departamento de Engenharia Rural, Lino, Gilmar, Hélio, César, Davilmar, Seu Antônio, Vanda e Sandra pela colaboração e amizade. Aos funcionários da Prefeitura do Campus Luiz de Queiroz, Bia, Márcia, Roseli e Rogério, pela amizade e apoio.

Aos amigos Thales e Lucia Helena, Benito e Lorena, Valdemício e Judith, , Welington e Rosana, Vagner e Andréa, Ivan e Inessa, Fabiano, Luis Fernando, Adriana e Alcester, Maurício, Carmello e Juliana, Raquel Furlan, Nádia, Renê, pelo apoio e amizade.

Finalmente, a todos que contribuíram ou torceram pelo sucesso deste trabalho. 


\section{SUMÁRIO}

Página

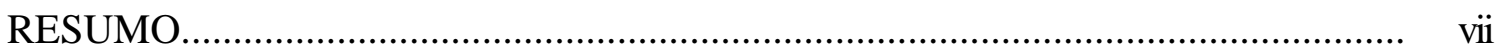

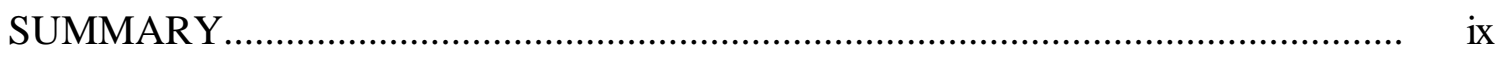

1 INTRODUÇÃO

2 REVISÃO DE LITERATURA....................................................................... 4

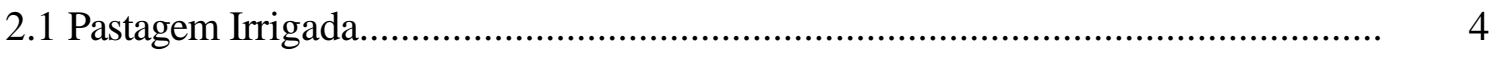

2.2 A Evapotranspiração........................................................................................ 10

2.2.1 Balanço de Energia.................................................................................... 17

3 IRRADIÂNCIA SOLAR GLOBAL E O SALDO DE RADIAÇÃO MEDIDAS

EM GRAMA BATATAIS (Paspalum notatum flugge) E CAPIM TANZÂNIA

(Panicum maximum Jacq.), EM PIRACICABA, SP............................................. 23

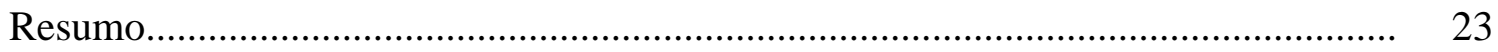

Summary

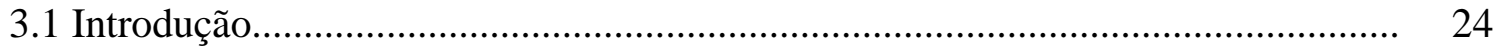

3.2 Material e Métodos....................................................................................... 27

3.3 Resultados e Discussão............................................................................... 29

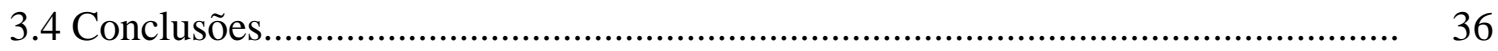

4 DESEMPENHO DE SISTEMAS AUTOMÁTICOS DE RAZÃO DE BOWEN SOBRE SUPERFÍCIE CULTIVADA COM GRAMA BATATAIS (Paspalum notatum flugge) ........................................................................................ 38

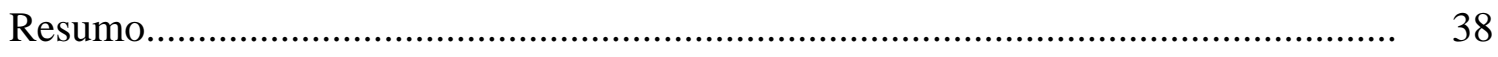




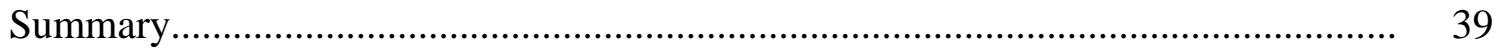

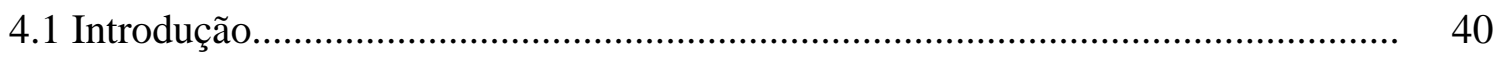

4.2 Material e Métodos........................................................................................ 41

4.3 Resultados e Discussão..................................................................................... 47

4.4 Conclusões............................................................................................ 51

5 VARIAÇÃO TEMPORAL DA EVAPOTRANSPIRAÇÃO DO CAPIM TANZÂNIA OBTIDA POR UM SITEMA AUTOMÁTICO DE RAZÃO DE BOWEN E UM LISÍMETRO DE PESAGEM....................................................... 52

Resumo ............................................................................................... 52

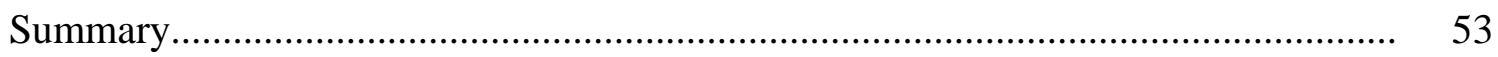

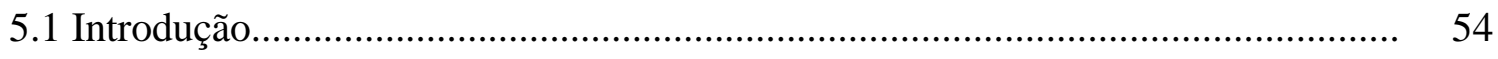

5.2 Material e Métodos.................................................................................. 56

5.3 Resultados e Discussão................................................................................... 60

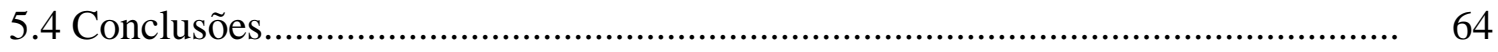

6 DETERMINAÇÃO DA EVAPOTRANSPIRAÇÃO DO CAPIM TANZÂNIA, UTILIZANDO UM SITEMA AUTOMÁTICO DE RAZÃO DE BOWEN E UM LISÍMETRO DE PESAGEM........................................................................... 66

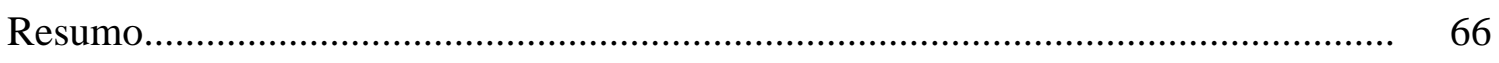

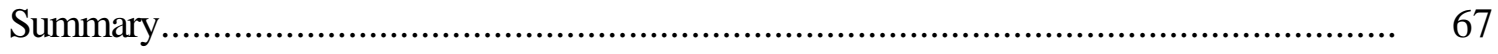

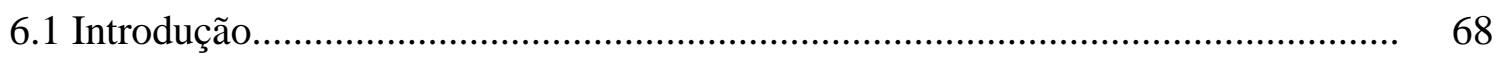

6.2 Material e Métodos....................................................................................... 69

6.3 Resultados e Discussão........................................................................................ 73

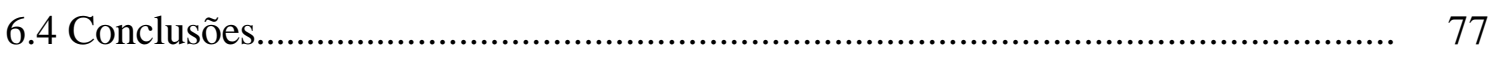

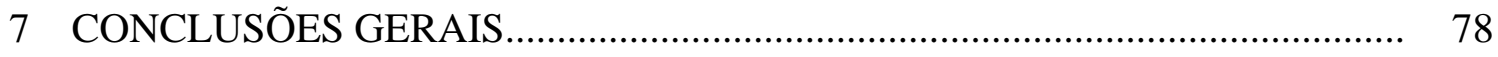

REFERÊNCIAS BIBLIOGRÁFICAS_.............................................................. 80 


\title{
EVAPOTRANSPIRAÇÃO DO CAPIM TANZÂNIA (Panicum maximum Jacq.) E GRAMA BATATAIS (Paspalum notatum flugge) UTILIZANDO O MÉTODO DO BALANÇO DE ENERGIA E LISÍMETRO DE PESAGEM
}

\author{
Autor: LEONARDO DUARTE BATISTA DA SILVA \\ Orientador: MARCOS VINÍCIUS FOLEGATTI \\ Co-orientador: NILSON AUGUSTO VILLA NOVA
}

\section{RESUMO}

A irrigação de pastagens no Brasil apresentou um crescimento acentuado nos últimos anos, porém devido a ausência de pesquisas sobre a aplicação de água em pastagens, o manejo da irrigação não vem sendo realizado de maneira racional. Os objetivos deste trabalho foram avaliar as relações entre a irradiância solar global e a radiação líquida sobre superfícies vegetadas com capim tânzania (Panicum maximum Jacq.) e com grama batatais (Paspalum notatum flugge); determinar a evapotranspiração do capim tânzania, por meio das medidas de lisímetro de pesagem; aplicar o método do balanço de energia para a estimativa da evapotranspiração do capim tânzania, por meio de um sistema automático de razão de Bowen; e comparar os valores de evapotranspiração do capim tanzânia, medidos em lisímetro de pesagem com os estimados pelo balanço de energia por meio de um sistema automático de 
razão de Bowen. O experimento foi conduzido em Piracicaba, estado de São Paulo. Por meio de um lisímetro de pesagem e um sistema automático de razão de Bowen foram obtidos valores de evapotranspiração do capim tanzânia (ETc). Também foram obtidos dados de irradiância solar global $(\mathrm{Qg})$ e radiação líquida $(\mathrm{Rn})$ sobre grama batatais e capim tanzânia. Os dados foram coletados diariamente e analisados, estatisticamente, mediante análise de regressão. Os modelos de regressão linear de estimativa da radiação líquida encontrados foram $\mathrm{Rn}=0,5418 \cdot \mathrm{Qg}\left(\mathrm{r}^{2}=0,9297\right)$ para uma superfície gramada e $\mathrm{Rn}=0,5613 . \mathrm{Qg}\left(\mathrm{r}^{2}=\right.$ 0,8719) para uma superfície vegetada pelo capim tanzânia. A evapotranspiração média do capim tanzânia foi de 4,13 mm.d ${ }^{-1}$, segundo o balanço de energia e 4,34 mm.d $\mathrm{d}^{-1}$, obtido pelo lisímetro de pesagem. Com base nos resultados, concluiu-se que o valores de evapotranspiração diários e horários do capim tanzânia medidos pelo sistema automático de razão de Bowen, foram afetados pelo efeito advectivo e pela precipitação, mas apesar disso houve uma razoável correlação com as medidas feitas em lisímetro de pesagem; e o estabelecimento das relações apresentadas neste trabalho mostra que os saldos de radiação em superfície gramada, assim como no capim tanzânia, podem ser estimados satisfatoriamente a partir da irradiância solar global, tendo a necessidade de se considerar suas variações sazonais. 


\title{
EVAPOTRANSPIRATION OF GUINEA GRASS (Panicum maximum Jacq) AND BAHIA GRASS (Paspalum notatum flugge) USING ENERGY BALANCE METHOD AND WEIGHING LYSIMETER
}

\author{
Author: LEONARDO DUARTE BATISTA DA SILVA \\ Adviser: MARCOS VINÍCIUS FOLEGATTI \\ Co-adviser: NILSON AUGUSTO VILLA NOVA
}

\section{SUMMARY}

Pasture irrigation presented a large growth in Brazil in recent years. However, the lack of research on pasture water use has led to inefficient irrigation management practices. The objectives of this work were: to evaluate the relationships between global solar irradiance and net radiation on surfaces covered with Guinea grass (Panicum maximum Jacq.) and Bahia grass (Paspalum notatum flugge); to determine the evapotranspiration of Guinea grass through weighing lysimeter measurements; to apply the energy balance method to estimate the evapotranspiration of Guinea grass by means of an automated Bowen ratio system; and finally to compare the evapotranspiration of Guinea grass measured by a weighing lysimeter versus the evapotranspiration estimated by the automated Bowen ratio energy balance system.. Evapotranspiration (ETc) was obtained for Guinea grass by means of a weighing lysimeter and an automated Bowen ratio system. Global solar irradiance $(\mathrm{Qg})$ and the net radiation $(\mathrm{Rn})$ over Bahia grass and Guinea grass were also obtained. The data were collected daily and statistically analyzed through regression analysis. The linear regression models for Rn estimates 
were $\mathrm{Rn}=0,5418 \cdot \mathrm{Qg}\left(\mathrm{r}^{2}=0,9297\right)$ for a Bahia grass surface and $\mathrm{Rn}=0,5613 \cdot \mathrm{Qg}\left(\mathrm{r}^{2}=\right.$ 0,8719 ) for a surface covered with Guinea grass. Guinea grass average evapotranspiration was $4.13 \mathrm{~mm} \cdot$ day $^{-1}$ by the energy balance method and $4.34 \mathrm{~mm}^{-1 a y^{-1}}$ as measured by the weighing lysimeter. The results led to the conclusion that the daily and hourly evapotranspiration values of Guinea grass obtained by the Bowen ratio automated system, were affected by the advection and by precipitation. Despite that, it was possible to obtain a correlation between the Bowen ratio evapotranspiration and measurements with the weighing lysimeter. The results show that the net radiation over Bahia grass and Guinea grass can satisfactorily be estimated from the global solar irradiance as long as seasonal variations are taken into account. 


\section{INTRODUÇÃO}

A irrigação de pastagens no Brasil apresentou um crescimento acentuado na década de 90, existindo atualmente centenas de sistemas tipo pivô-central irrigando pastos no país. Esta prática iniciou-se devido ao declínio de algumas culturas agrícolas que eram irrigadas por aspersão, principalmente por sistemas de pivô-central. Os produtores rurais passaram a utilizar o pivô-central a fim de suprir a necessidade hídrica das pastagens obtendo, como consequência, incremento no peso do gado de corte durante os períodos de estiagem. Com esta nova prática, os pecuaristas principalmente do Centro-Oeste, Sudeste e Nordeste brasileiro, obtiveram inicialmente ótimos resultados. Porém com o passar dos anos, os bons resultados não foram mantidos pois o manejo da irrigação não era realizado de maneira eficiente, principalmente por falta de recomendações técnicas e que ainda hoje são praticamente inexistentes na literatura, no que se refere àirrigação de pastagens.

A aplicação de água às pastagens não tem sido feita de modo correto, e na maioria das vezes, ocorre aplicação excessiva de água, ocasionando prejuízos ao ambiente ao longo do tempo, o que resulta na redução da produção da matéria verde. Como exemplos desses problemas podem ser citados: o consumo desnecessário de energia elétrica e de água; lixiviação dos nutrientes e a maior compactação do solo, que repercutem na diminuição da vida útil da pastagem.

A determinação do consumo hídrico das culturas é de fundamental importância para que a aplicação de água seja feita de maneira racional. Para se atingir essa meta faz-se necessário o conhecimento de um processo natural denominado evapotranspiração. 
A evapotranspiração pode ser obtida de diferentes maneiras: de forma indireta, a partir de fórmulas teóricas ou empíricas que utilizam dados do solo e dados meteorológicos; ou de forma direta, por meio de lisímetros e do balanço hídrico do solo.

Os métodos indiretos, que se baseiam no solo, consideram-o como um reservatório capaz de armazenar certa quantidade de água. Os métodos meteorológicos utilizam basicamente informações meteorológicas como entradas para modelos que calculam a quantidade de água evapotranspirada pela cultura durante um certo período de tempo. Variáveis como temperatura da cobertura vegetal, potencial de água na folha, variações do diâmetro de caules e frutos estão sendo estudadas. No entanto, a utilização de modelos baseados no clima ou em indicadores vegetais, implica em sua calibração e adequação para as condições locais específicas.

A determinação da evapotranspiração por meio de medidas em lisímetros é uma operação de difícil execução em condições de campo. Visando minimizar essas dificuldades, vários pesquisadores procuraram desenvolver métodos de estimativa da evapotranspiração, relacionando a perda de água de superfícies naturais com dados meteorológicos mais facilmente disponíveis.

Estimativas meteorológicas do fluxo de água na atmosfera podem fornecer valores representativos da evapotranspiração. O maior obstáculo deste tipo de mænsuração é a disponibilidade, o custo e a dificuldade de instalação e operação dos instrumentos. Com o recente desenvolvimento tecnológico de sensores e sistemas de aquisição de dados, tem sido possível mensurar de forma direta e em tempo real a evapotranspiração com um custo relativamente baixo.

O balanço de energia das superfícies vegetadas permite dimensionar as trocas de massas e energia no sistema solo-planta-atmosfera, por meio do estudo da participação do saldo de radiação nos diversos processos que ocorrem na cultura. $\mathrm{O}$ método permite avaliar 
as alterações no microclima da vegetação em função dos estádios de desenvolvimento da cultura e em função das condições do solo e da atmosfera.

De acordo com as descrições anteriores, este trabalho visa atingir os seguintes objetivos:

a) avaliar as relações entre a irradiância solar global e a radiação líquida sobre superfícies vegetadas com capim tânzania (Panicum maximum Jacq.) e com grama batatais (Paspalum notatum flugge);

b) avaliar o desempenho de sistemas automáticos de razão de Bowen na estimativa da evapotranspiração de referência e comparar os valores estimados pelo balanço de energia com os estimados pelo modelo de Penman-Monteith e com os medidos em lisímetro de pesagem;

c) analisar a variação temporal da evapotranspiração do capim tânzania (Panicum maximum Jacq.), utilizando um sistema automático de razão de Bowen e um lisímetro de pesagem;

d) determinar a evapotranspiração do capim tânzania (Panicum maximum Jacq.) utilizando lisímetro de pesagem;

e) aplicar o método do balanço de energia para a estimativa da evapotranspiração do capim tânzania (Panicum maximum Jacq.), por meio de um sistema automático de razão de Bowen; $\mathrm{e}$

f)comparar os valores de evapotranspiração do capim tanzânia (Panicum maximum Jacq.), medidos em lisímetro de pesagem com os estimados pelo balanço de energia por meio de um sistema automático de razão de Bowen. 


\section{REVISÃO DE LITERATURA}

\subsection{Pastagem Irrigada}

A utilização da irrigação na produção de forragens no Brasil teve um grande avanço nos últimos anos. Em algumas fazendas, a exploração de grãos (soja, milho, feijão etc.) irrigados por pivô-central, apresentou um significativo declínio o que estimulou os agricultores a começarem a investir na pecuária. Com isso, uma alternativa encontrada principalmente em Goiás, Norte de Minas e no Sul da Bahia, foi utilizar esse sistema de irrigação na produção de forragens. Vários produtores (de gado de leite e de corte), visando maior eficiência, com custos ajustados a uma rentabilidade planejada, estão investindo na irrigação de forragens. $\mathrm{Na}$ região de Governador Valadares, MG, já existem dezenas de produtores que vêm garantindo o fornecimento da água às forragens com sistema fixo de aspersão. Na região Sudeste, sistemas "autopropelido" estão também sendo usados na irrigação de pastagens (Silva \& Folegatti, 2001).

Hillesheim (1994) cita que a irrigação em pastagens é preconizada para atender a duas finalidades: a primeira seria a de diminuir o efeito da sazonalidade, com objetivo de aumentar a produção na estação seca e com isso alcançar maior equilíbrio durante o ano; a segunda seria a de obter, simplesmente, aumento de produção de matéria seca durante o ano, independente da sua sazonalidade.

O primeiro objetivo se baseia no fato que a sazonalidade seria provocada pela escassez de chuvas no período da estação seca. Neste sentido, um dos trabalhos esclarecedores, realizado em Piracicaba por Ghelfi Filho (1972), teve por objetivo estudar três níveis de irrigação comparados com uma testemunha. $\mathrm{O}$ autor observou que em nenhum dos três níveis de irrigação foi constatada alteração na produção estacional, o que contradiz o primeiro objetivo, no qual a irrigação é preconizada para pastagens. Mesmo que a irrigação 
fosse utilizada somente no período seco, com a finalidade específica de "corrigir" o efeito da seca, pouco êxito se obteria para equilibrar a produção.

Também em Piracicaba, Ghelfi Filho (1976), realizou trabalho com a intenção de diminuir ou eliminar a sazonalidade na produção do capim colonião (Panicum maximum, Jacq.) utilizando a irrigação. Foi observado que a produção de matéria seca no inverno foi igual a $25,1 \%$ do total anual. A irrigação proporcionou aumento significativo de cerca de 27,8\% na produção, mas também não alterou a sazonalidade da produção, pois tanto para a testemunha como para os outros tratamentos a produção no verão foi de $75 \%$ do total. Utilizando a irrigação somente na estação seca o autor verificou um aumento de produção de $44 \%$ em relação à testemunha, bastante satisfatório, mas sem resolver completamente o problema da sazonalidade.

Assim, segundo Ghelfi Filho (1972), a indisponibilidade de água no solo no período seco não é tão importante, uma vez que a evapotranspiração é reduzida nesta época do ano, que nas condições do estudo coincidem com o inverno. Desta forma, os resultados obtidos por Ghelfi Filho (1972), em Piracicaba, SP, Andrade et al. (1972), em Ituiutaba, MG e Capineira (1972), em Seropédica, RJ , citados por Hillesheim (1994), não registraram efeito prático sensível capaz de minimizar os efeitos da sazonalidade.

A segunda finalidade de irrigar a pastagem, de acordo com Hillesheim (1994), seria obter incremento da produção de matéria seca, independente do período do ano. Este autor verificou, de acordo com Andrade et al. (1972), Ghelfi Filho, (1972) e Ghelfi Filho, (1976), que a irrigação pode contribuir para a obtenção de incrementos de matéria seca (MS) da ordem de 18 a $28 \%$, sendo essa porcentagem, idêntica para o inverno e para o verão.

Na área biológica, a diversidade dos componentes de um sistema de produção é uma constante. Dentro desta realidade deve-se pensar e estabelecer sistemas de suprimento de forragem nutritiva para diferentes condições ambientais, os quais são necessários para a exploração eficiente e lucrativa de distintas atividades pecuárias (Maraschin, 1996).

A produtividade de pastagens manejadas intensivamente vem aumentando sensivelmente na última década, principalmente devido a um preparo melhor do solo, uso de 
fertilizantes, melhores variedades, etc. Como resultado de todas essas melhorias, a água no solo tem se tornado, freqüentemente, o fator limitante da produtividade, mesmo em climas considerados úmidos (Reichardt, 1978).

A água no solo afeta a transformação e absorção de nutrientes, afetando, portanto, a eficiência dos fertilizantes. São inúmeros os trabalhos que evidenciam este fato. Como nas diferentes culturas, diferentes partes da planta são colhidas, o manejo da água deve ser adequado para cada caso em particular. Em culturas cujo objetivo é a produção de folhas e caules, como as forrageiras, é desejado um crescimento vegetativo máximo. Neste caso, altos potenciais de água (alta umidade) são desejados, porém a umidade do solo não deve ser mantida em valores extremamente altos, porque, neste caso, a aeração do perfil do solo fica prejudicada, o que pode levar a um decréscimo substancial da produção (Reichardt, 1978)

A elevada energia incidente nos trópicos e sub-trópicos proporciona surpreendentes produções de forragem, mas provoca freqüentemente um aumento significativo da evapotranspiração que poderá causar escassez temporária de água às plantas. Cooper \& Taiton (1968) afirmam que, devido ao fato das altas temperaturas e da maior quantidade de energia recebida nas regiões tropicais serem concentradas em dias mais curtos do que aqueles de clima temperado, a evapotranspiração é mais acentuada, a ponto de tornar a disponibilidade de água o fator mais limitante ao crescimento de plantas nos trópicos. Assim, o manejo de forrageiras nestas regiões deve procurar uma maior eficiência no uso da água, que é expressa pela quantidade de matéria seca produzida por volume de água utilizada.

Segundo Rodrigues \& Rodrigues (1987), verificaram um pequeno aumento na produção da pastagem após ter sido adicionado o nitrogênio. A adição de água dobrou a produção em vários anos de estudo. Porém, a adição conjunta de água e nitrogênio aumentou a produção de matéria seca em cerca de 5 a 8 vezes em relação ao tratamento controle.

O experimento de Frizzone (1994), visando estudar os efeitos da irrigação suplementar e da adubação nitrogenada na produtividade de aveia (Avena saliva L.), para forragem, mostrou que existem diversas combinações entre nitrogênio e água para uma mesma produção de matéria seca. 
Trabalhos preliminares de irrigação de forrageiras no Brasil, embora com limitações na quantidade de água fornecida, mostram que existe potencial para incremento nos níveis de produtividade (Alvim 1986; Botrel et al. 1991).

Herrera (1985) em seu experimento, realizado em Cuba, com três espécies de forrageiras tropicais (Cynodon dactylon, Panicum maximum, Cenchius ciliaris) com três diferentes doses de água (capacidade de campo em 90, 80 e $70 \%$ ) durante dois anos cita que não houve interação significativa entre irrigação e espécie forrageira. Os aumentos ficaram em torno de $37 \%$ acima da testemunha, porém em 50\% do "período seco" não houve aumento na matéria seca (MS).

Ladeira (1966), em estudo sobre produção e irrigação dos capins pangola, gordura e sempre-verde, verificaram que no segundo corte (período seco) a irrigação e a adubação tiveram efeito favorável sobre a produção de massa verde, aumentando-a em $50 \%$ para o capim sempre-verde e quase dobrando para os capins pangola e gordura.

Perez (1986), estudou várias frequiências de irrigação em pastagens tropicais, em Cuba, e obteve aumentos de 50 a $100 \%$ por corte, passando em alguns casos de 4,5 t para 9,0 t de MS/ha por corte.

Pereira (1966), realizou um estudo em Prudente de Morais, MG, comparando a produção de dez gramíneas para o uso de capineiras e verificaram que a combinação da prática da irrigação e adubação nitrogenada promoveram incrementos à produção, duplicando-a ou mesmo triplicando-a, em relação à produção das parcelas testemunhas. Observou-se também que, quando a água e fertilizantes foram aplicados simultaneamente, o aumento de produção obtido foi maior do que quando se somaram os efeitos isolados da irrigação e adubação, chegando a um aumento de produção de 169\% sobre a testemunha. Embora os autores não tenham estudado os efeitos da temperatura, durante a estação da seca, os resultados obtidos apontaram a umidade do solo como um dos principais fatores limitantes do crescimento das gramíneas naquela região. 
Tafur (1990), realizando um trabalho sobre a interação da irrigação e a fertilização sobre a produção em capim elefante, na Colômbia, demonstrou que a produção teve aumento bastante significativo, de mais de $300 \%$ em um corte.

Em revisão realizada por Rolim (1994), relata-se que nas regiões áridas e semi-áridas, a deficiência hídrica, com chuvas anuais de 508 a $762 \mathrm{~mm}$, irregularidade das precipitações pluviais ao passar dos anos e sua má distribuição constituem os principais fatores climáticos limitantes da produção de forragens (Dantes \& Skidmore, 1966). McDowell (1972) analisando o problema da produção de forragens em climas tropicais, por meio de dados da FAO, concluiu que a temperatura e a deficiência hídrica são as principais causas limitantes da produção de forragens compreendidas entre as latitudes de $30^{\circ}$ Norte e $30^{\circ} \mathrm{Sul}$. Segundo o mesmo autor, citado por Rolim (1994), o crescimento das plantas é limitado por apenas um dos elementos ou pela associação dos dois.

Ainda sobre o trabalho de Rolim (1994), este autor determinou que os fatores climáticos responsáveis pela sazonalidade de produção de plantas forrageiras variam de uma região a outra, bem como as respostas a esses "fatores" são variáveis de acordo com a espécie. E que as plantas forrageiras tropicais, citando Cooper \& Taiton (1968), apresentam taxa de fotossíntese máxima às temperaturas $30-35^{\circ} \mathrm{C}$ e mínima à temperatura de $15^{\circ} \mathrm{C}$. Portanto, as baixas temperaturas noturnas nas regiões dos trópicos e subtrópicos são apontadas como principais agentes causadores da sazonalidade de crescimento das plantas forrageiras tropicais.

Assim, admite-se que na região Sudeste do Brasil, bem com em altas latitudes, a sazonalidade da produção é uma decorrência das baixas temperaturas ou fatores correlatos. Deve-se ressalvar que apesar destes fatos, à medida que se aproxima da linha do Equador, espera-se que a irrigação no período seco tenha altas respostas (Hillsheim, 1994).

No Sudeste do Queensland, Austrália, foi verificado que o crescimento do capim pangola era insignificante quando a temperatura noturna caía abaixo de $15^{\circ} \mathrm{C}$, embora ocorresse radiação solar acima de $12,5 \mathrm{MJ} \cdot \mathrm{m}^{-2} \cdot \mathrm{d}^{-1}$. Naquela região, o crescimento da planta forrageira foi limitado por 5 meses. Contudo, um dos grandes problemas da interpretação de 
resultados experimentais em ambientes sob condições controladas, pode ser a dificuldade de se separar os efeitos da interação da luz (fotoperíodo e intensidade de luz) e temperatura no crescimento de plantas, (Moore \& Russel, 1976, citados por Rolim, 1994).

A associação de baixas temperaturas e curtos fotoperíodos foram os principais fatores climáticos limitantes do crescimento de plantas forrageiras tropicais e subtropicais, conforme os trabalhos de t'Mannetje \& Pritchard (1974), t'Mannetje (1975) e Sweeney \& Hopkinson (1975), citados por Rolim (1994). Porém, observa-se que o crescimento relativo de gramíneas tropicais e subtropicais, sob condições de oscilação de temperatura diurna-noturna e fotoperíodo, cuja influência sobre a produtividade foi estudada por t'Mannetje \& Pritchard (1974), sofre efeito mais pronunciado da temperatura do ar.

Os dados de Corsi (1994), mostram que o fotoperíodo tem influência na produtividade das gramíneas testadas. Contudo, o efeito da temperatura é bem mais significante.

Além dos processos fisiológicos e morfológicos, o crescimento da planta forrageira sob estresse hídrico pode ser prejudicado pela redução na absorção de nutrientes, como nitrogênio, cálcio e fósforo (Turner \& Begg, 1978 e Norton, 1982, citados por Corsi 1994). As camadas superficiais do solo, que concentram a maior parte dos nutrientes, secam rapidamente, não permitindo a absorção desses elementos.

O uso de irrigação em pastagens como alternativa para auxiliar na regularização da curva de sazonalidade de produção da planta forrageira ou para evitar queda de produção devido a estiagem prolongada durante o período chuvoso, tem aumentado significativamente, face aos excelentes resultados reportados na terminação de bovinos sob pivô-central por alguns pecuaristas no Centro-Oeste (latitudes $14^{\circ}-15^{\circ}$ ), renovando o interesse na irrigação de pastagens (Medeiros, 1997). Esses resultados, dão conta de um ganho de1arroba/mês apenas com rotação de pastagem adubada e sal mineral, isto com uma lotação de 9-10 unidade animal/ha. Com este apelo, nos estados de Goiás e Mato Grosso, tem havido uma verdadeira corrida ao pivô central por muitos pecuaristas. 


\subsection{A Evapotranspiração}

É necessário conhecimento minucioso de certas definições, quando se trata da quantificação da evapotranspiração e do requerimento de água das culturas. Mensurações históricas, têm sido realizadas sob diferentes condições, e os dados resultantes assumem diferentes conceitos. Comparações e interpretação de dados de evapotranspiração, dependem sobretudo do uso correto das definições. Por exemplo, o incorreto conhecimento das definições, pode levar a um intercâmbio de dados e métodos de estimativa não compatíveis (Jensen et al., 1990).

A evaporação da água é um fenômeno físico que propicia a mudança de estado da fase líquida para a gasosa diretamente de uma superfície de água livre (mar, lago, rio, etc) ou úmida (planta, solo). Quando esta mudança se dá através das plantas recebe o nome de transpiração. No caso de solos parcialmente vegetados estes processos ocorrem simultânea e interdepedentemente, sendo utilizado o termo evapotranspiração (Berlato \& Molion, 1981).

Thornthwaite (1948) definiu a evapotranspiração potencial (ETP) como a quantidade de água utilizada por uma extensa superfície vegetada, em crescimento ativo, sob condições ótimas de umidade do solo. A evapotranspiração de referência (ETo) foi definida por Doorenbos \& Pruitt (1977) como sendo a água utilizada por uma extensa superfície de grama, em crescimento ativo, com altura de 0,08 a $0,15 \mathrm{~m}$, cobrindo totalmente o solo e sem deficiência de água. Esta referida definição da ETo é coincidente com a da ETP proposta por Thornthwaite, em 1948. Já Jensen (1973) propôs a cultura da alfafa como referência e definiu como evapotranspiração de referência aquela que se verifica em uma área sem deficiência hídrica, com bordadura mínima de $100 \mathrm{~m}$, cultivada com a referida cultura, e apresentando um porte de 0,30 a 0,50 m de altura. A evapotranspiração real ou atual (ETr) é aquela que ocorre em uma superfície vegetada, independente de sua área e das condições de umidade do solo (Thornthwaite, 1948; Pruitt et al., 1972; Villa Nova \& Reichardt, 1989; Pereira, 1998). 
Penman (1956) definiu evapotranspiração potencial como "a quantidade de água utilizada na unidade de tempo por uma cultura de porte baixo e verde, cobrindo totalmente a superfície, com altura uniforme e sem deficiência hídrica”. Culturas de porte baixo estão implícitas nesta definição. No entanto, o autor aplicou esse conceito às gramas de porte baixo. A evapotranspiração de culturas irrigadas pode ser de 10 a $30 \%$ maior do que a ocorrida em superfície gramada, dependendo do índice de área foliar.

O conceito de evapotranspiração da cultura (ETc) foi introduzido por Doorenbos \& Pruitt (1977), caracterizando-a como sendo a evapotranspiração de uma cultura agronômica, livre de doenças, desenvolvendo-se em uma área cultivada de um ou mais hectares, sob condições otimizadas de solo, incluindo água e fertilidade.

Jensen et al. (1990) afirmaram que na prática a estimativa da evapotranspiração de uma cultura específica (ETc) envolve o cálculo da evapotranspiração potencial (ETP), aplicando-se posteriormente coeficientes de cultivo $(\mathrm{Kc})$. Outras formas de se estimar a evapotranspiração potencial (ETP) são possíveis. Como por exemplo, o uso da evaporação de uma superfície de água livre. Contudo, a taxa de evaporação de tanques varia com o tamanho do tanque e com as condições de contorno. O mesmo autor sugere que a ETo pode ser definida como "a taxa com que a água, se disponível, é removida da superfície do solo e das plantas, de uma cultura específica, arbitrariamente chamada de cultura de referência". A ETo é normalmente expressa como taxa de calor latente por unidade de área e tempo ou lâmina de água evaporada por tempo. A ETo é equivalente a evapotranspiração potencial com uma especificação adicional de que ela representa a evapotranspiração de uma cultura com umidade do solo ideal e cobertura total da área.

A evapotranspiração é função dos elementos meteorológicos, do solo e da planta (Lemon et al, 1957). Penman (1956) argumenta que quando a cobertura do solo é completa e não há restrição hídrica, a ETo é condicionada principalmente pelos elementos meteorológicos. A radiação líquida é o principal elemento meteorológico, que influencia a evapotranspiração (Pelton et al, 1960; Tanner \& Lemon, 1962; Villa Nova et al, 1976). A 
importância relativa da radiação líquida, da umidade relativa do ar e da velocidade do vento na ETo é da ordem de 80:6:14, respectivamente, dependendo logicamente do local e das condições meteorológicas vigentes (Mukammal \& Bruce 1968, citado em Berlato \& Molion, 1981). Villa Nova (1987) ressalta que é difícil separar a ação de cada um desses elementos, pois os mesmos agem simultaneamente e se interrelacionam. Assim, de maneira geral, para uma dada região, quanto maior for a disponibilidade de energia solar, temperatura do ar e velocidade do vento, e quanto menor for a umidade relativa do ar, maior deverá ser a taxa de evapotranspiração potencial ou de referência. Em regiões onde ocorrem advecções fortes, condição que comumente ocorre quando uma área úmida é circundada por uma área seca, a importância relativa da radiação líquida decresce, e em adição a ela, a advecção ou transferência de calor sensível das áreas secas circunvizinhas, contribuirá no processo evapotranspirativo com energia até maior que aquela disponível à área úmida, aumentando desta forma a importância da velocidade do vento e umidade relativa do ar na evapotranspiração. Nesse tem-se a evapotranspiração de oásis (ETO), já que a bordadura é insuficiente.

A advecção é definida como a troca de energia, umidade ou "momentum" devido à heterogeneidade horizontal. Millar (1964) trabalhando com um campo irrigado de Trifolium repens L. concluiu que a advecção ocasiona um consumo de calor latente superior ao suprimento de radiação local para uma considerável faixa após a interface seco/úmido e que houve um decréscimo da evaporação à medida que se afastava da interface seco/úmido. Pelton et al. (1960) denominaram-na "efeito varal". À medida que se afastava da interface, dependendo do tamanho da área tampão, a evapotranspiração decresce e pode atingir a evapotranspiração potencial. O tamanho da área tampão dependerá das condições locais. Resultados de Goltz \& Pruit (1970), citados por Pereira (1998), trabalhando em condições semi-áridas de Davis, Califórnia, concluíram que o tamanho adequado para se minimizar o efeito advectivo deve ser maior que 100 metros, para um campo cultivado com grama rasteira. Para condições áridas de Israel, Stanhill (1961) mostra que para um campo de alfafa o tamanho deve ser superior a $300 \mathrm{~m}$. 
De acordo com Burman et al. (1983) a evapotranspiração pode ser mensurada a partir de medidas diretas ou estimada por meio de informações climáticas. No primeiro grupo, entre outros, estão incluídos os diferentes tipos de lisímetros e o balanço de água no solo; enquanto no segundo, estão enquadrados os métodos teóricos e empíricos, como os de Penman (1948), Thornthwaite (1948), Blaney \& Criddle (1950), Jensen \& Haise (1963), Priestley \& Taylor (1972), Hargreaves (1977) e evaporímetros como o tanque "Classe A", dentre outros.

Os lisímetros são equipamentos constituídos de uma caixa impermeável sendo a mesma preenchida com solo, sendo mantida a mesma sequência de horizontes do solo original. Os lisímetros, quando corretamente instalados, possibilitam medidas precisas da evapotranspiração. Para Mantovani (1993), os lisímetros são parcelas experimentais onde é feito o balanço hídrico.

Aboukhaled et al. (1982) ressalta que os lisímetros devem ser preenchidos corretamente, assemelhando-se o máximo possível às camadas de solo da área externa, e localizados de maneira a representar um ambiente específico. Quando adequadamente preenchidos, os lisímetros apresentam valores de evapotranspiração representativos da área circundante (Pruitt \& Angus, 1960; Howell et al., 1991). Na definição da localização do lisímetro deve-se evitar obstáculos que possam alterar a radiação incidente e/ou o padrão de vento (Ritchie \& Burnet, 1968).

Os lisímetros podem apresentar diversos frmatos e tamanhos e de acordo com a maneira de medição são classificados em: de pesagem, de drenagem, de lençol freático de nível constante e de flutuação. Para Howeel et al. (1991), a forma e área do lisímetro devem ser definidas a partir do tipo de cultura a ser utilizada, principalmente, em função da dimensão do sistema radicular da mesma.

O lisímetro de pesagem é constituído de uma caixa impermeável sob a qual é instalada uma célula de carga, cuja finalidade é medir a variação de peso da mesma. O lisímetro de pesagem apresenta resultados satisfatórios em campos experimentais (Silva et al., 1999a; 
Fernandes, 1996; Folegatti et al., 1997; Campeche 2002). Os lisímetros de drenagem são normalmente constituídos de caixas com paredes impermeáveis enterradas até o nível do solo, plantados com vegetação idêntica a do terreno circundante, tendo no fundo da caixa um dreno, conectado a um vaso, no qual o excesso de água percolado é captado e medido (Camargo, 1971). O lisímetro de lençol freático constante consiste, além da caixa impermeável com solo e vegetação, de um sistema automático de reposição de água possibilitando que o lençol freático, no interior da caixa, permaneça em nível constante, sendo a evapotranspiração proporcional à água que sai do reservatório (Cruz, 1995). O lisímetro de flutuação consiste de um volume de solo contido num reservatório que flutua num fluido de alta densidade, por exemplo o $\mathrm{ZnCl}_{2}$ (Pereira et al. 1997).

Silva et al. (1999a) avaliaram três tipos de lisímetros (de pesagem, de drenagem e com lençol freático de nível constante) na determinação da evapotranspiração de referência (ETo). Segundo os autores, o lisímetro de pesagem mostrou-se eficiente na medida diária da evapotranspiração de referência ao passo que os outros dois apresentaram um melhor funcionamento em períodos de 5 dias. Silva et al. (1999b), analisando o funcionamento de um lisímetro com sistema de pesagem portando três células de carga, concluíram que o mesmo possui capacidade de realizar mensurações num espaço inferior a uma hora. Para Howeel et al. (1991), os lisímetros de pesagem são os mais utilizados em períodos menores que um dia. Entretanto, Ritchie \& Burnett (1968) afirmaram que intervalos de integração inferiores a 15 minutos são pouco recomendáveis.

Na ausência de medidas diretas, como as obtidas por meio dos lisímetros, a evapotranspiração pode ser estimada por diversos métodos. Segundo Pereira et al. (1997) pode-se dividi-los de acordo com os princípios envolvidos em cinco categorias: empíricos, aerodinâmico, balanço de energia, combinados e correlações dos turbilhões.

Os métodos empíricos, tais como o do tanque Classe A, de Thornthwaite, de Camargo, de Makink, da Radiação Solar, de Hargreaves-Samani, etc., são, normalmente, resultantes de correlações entre a evapotranspiração medida em condições padronizadas e os elementos meteorológicos medidos em postos também padrões. O método aerodinâmico é um 
método micrometeorológico com embasamento fisico-teórico da dinâmica dos fluídos e transporte turbulento. O método de balanço de energia representa a contabilidade das interações dos diversos tipos de energia com a superfície. Os métodos combinados retratam os efeitos do balanço de energia com aqueles do poder evaporante. O método dos turbilhões baseia-se nos deslocamentos verticais da atmosfera e conseqüente transporte das suas propriedades (Pereira et al. 1997).

O método combinado de Penman é amplamente utilizado porque facilita o entendimento dos processos físicos da evaporação de superfícies naturais e, também, porque se utiliza informações meteorológicas coletadas em um único nível acima da superfície evaporante (Thom \& Oliver, 1977; Brutsaert, 1982; Luchiari Jr., 1988). Porém, verifica-se que o método original de Penman não é um caso geral para estimativa da evapotranspiração, mas sim um caso muito particular aplicado a superfícies de água livre, como um lago ou tanque "Classe A", ou a superfícies molhadas como uma vegetação após uma chuva ou irrigação por aspersão (Monteith, 1965; Thom, 1975; Monteith, 1973; Brutsaert, 1982; Monteith, 1985; Oke, 1992).

Muitos pesquisadores procuraram superar esta falta de generalidade do método de Penman, cabendo a Monteith (1965) a obtenção de uma equação geral válida para qualquer tipo de vegetação, sob qualquer condição de estresse hídrico. Ele generalizou o método de Penman através de uma analogia com a lei de Ohm para os circuitos elétricos, introduzindo no termo aerodinâmico a resistência à transferência do vapor de água do dossel.

Smith (1991) propôs que se adotasse uma definição padronizada para a evapotranspiração de referência, com vistas, principalmente, à utilização do modelo de Penman com as modificações propostas por Monteith. A evapotranspiração de referência seria aquela que ocorre em uma cultura hipotética, apresentando as seguintes características: altura de 0,12 m, resistência do dossel de 69 s.m $^{-1}$ e coeficiente de reflexão (albedo) de $23 \%$, desde que bem suprida de água. 
O método de Penman-Monteith, apesar de ter uma formulação teórica rigorosamente física, de fácil entendimento e requerer a utilização de informações meteorológicas padronizadas, tem sua aplicação prática limitada pelas dificuldades de se obter valores confiáveis e representativos para a resistência do dossel (Norman \& Campbell, 1983; Monteith, 1985; Luchiari Jr., 1988; Hatfield, 1988; Villa Nova \& Reichardt, 1989; Luchiari Jr. \& Riha, 1991 e Oke, 1992).

As dificuldades para se estimar a resistência do dossel decorrem do fato de ser uma função composta de muitos fatores ambientais e biológicos, tais como radiação solar, déficit de saturação de vapor de água, disponibilidade de água no solo, índice de área foliar (IAF), idade da planta, entre outros, cujos efeitos individuais não são fáceis de serem isolados (Monteith, 1985).

A resistência do dossel (rc) pode ser estimada a partir de medidas diretas da resistência estomática média, com porômetros de difusão, e do índice de área foliar da planta, obtido por amostragem. No entanto, esta é uma tarefa árdua e trabalhosa. Os valores

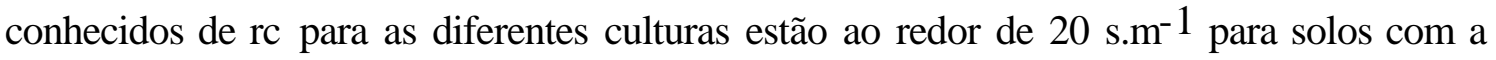
umidade próximo à capacidade de campo, aumentando à medida que a umidade do solo diminui. Este fato evidencia a necessidade de se pesquisar a variação desta resistência em função da disponibilidade de água no solo. Tal parametrização de rc, para condições ótimas e de restrição de água no solo, permitirá que se estime a evapotranspiração real a partir do modelo Penman-Monteith (Hatfield, 1988).

Monteith (1985) sugere que se adote $\mathrm{rc}=50 \mathrm{~s} \cdot \mathrm{m}^{-1}$ para a determinação da evapotranspiração potencial das plantas cultivadas. Este valor concorda com os valores apresentados por Oke (1992) listados a seguir: grama, $70 \mathrm{s.m}{ }^{-1}$; culturas agrícolas, 50 s.m ; florestas, 80 a $150 \mathrm{~s} \cdot \mathrm{m}^{-1}$.

Maggiotto (1996), estimando os valores de resistência de dossel como resíduo de utilização do modelo de Penman-Monteith, a partir das variáveis meteorológicas médias no 
período de 24 horas e utilizando a ETo medida em um lisímetro de pesagem, encontrou valores que variaram de 53 a $256 \mathrm{~s} . \mathrm{m}^{-1}$, com valor médio de 144 s.m $\mathrm{m}^{-1}$.

Campeche (1997) verificou que os valores de resistência do dossel estimados a partir da termometria ao infra-vermelho foram bastante próximos do valor parametrizado pela FAO. Utilizando um período maior de dados durante a estação seca, Pereira (1998) observou nesse período um valor de resistência do dossel igual a 40 s.m-1 .

\subsubsection{Balanço de Energia}

O método do balanço de energia constituí-se, basicamente, na partição do saldo de radiação nos fluxos de calor latente de evapotranspiração e nos fluxos de calor sensível no ar e no solo. Em certos momentos, os fluxos de calor sensível podem passar de consumidores para doadores de energia para o processo evapotranspirativo. A metodologia do balanço de energia, e consequentemente da razão de Bowen, já foi amplamente estudada, para algumas culturas (Tanner, 1960; Villa Nova, 1973; Dunin et al., 1989; Kroon, 1989; Mastrorilli et al., 1989; Peterscmitt \& Katerji, 1989; Fontana et al., 1991; Maki, 1991; Moura \& Martins, 1992; Herbst et al., 1996; Bergamaschi et al., 1988; Steduto \& Hsiao, 1998).

A relação entre o fluxo de calor sensível do ar e o fluxo de calor latente de evapotranspiração constitui-se na razão de Bowen, conceito introduzido por Bowen (1926). A referida razão apresenta valores bem distintos quando há diferenças significativas com relação a umidade do solo sendo que, normalmente, quanto mais úmido o solo mais próximos de zero tendem a ser os valores da mesma, pois, maiores quantidades de energia são direcionadas ao processo de evapotranspiração. Quando há restrição hídrica uma maior parte da energia é utilizada no aquecimento do ar, o que resulta em um valor elevado da razão de Bowen. Reschke et al. (1997), em Ji-Paraná, RO, encontraram, em média, os seguintes valores para a estação chuvosa: 0,21 na área de floresta e 0,30 na área de pastagem. Para a 
estação seca os valores obtidos para a floresta e pastagem foram de 0,26 e 0,31, respectivamente. Cargenel et al. (1996) obtiveram com feijão valores próximos a zero, um dia após o mesmo ser irrigado. Relataram, ainda, que à medida que a umidade do solo foi diminuindo os valores da razão de Bowen aproximaram-se de 0,45. Gutiérrez \& Meinzer (1994) encontraram, em cultivo de café, variações nos valores médios da razão de Bowen com a alteração dos valores do índice de área foliar. Segundo os autores, em condições ideais de umidade do solo, a razão de Bowen diminui de 0,92 para 0,36 quando o índice de área foliar aumentou de 1,4 para 6,7.

Bergamaschi et al. (1998) observaram em cultivo de feijoeiro, que maiores quantidades de energia foram disponibilizadas para a evapotranspiração quando a disponibilidade hídrica era maior. Além disso, segundo os autores, essa disponibilização de energia também tem relação direta com o aumento da demanda evaporativa da atmosfera e do índice de área foliar. Lira \& Oliveira (1997) analisaram as diferenças do balanço de energia sobre um canavial, na zona da mata alagoana, e concluíram haver diferenças significativas quando se compara os valores de saldo de radiação e a partição do mesmo nas estações do inverno e verão. Em julho, segundo os autores, o saldo de radiação médio foi de 8,78 MJ.m ${ }^{2} \cdot \mathrm{d}^{-1}$ e $66 \%$ deste total foi utilizado pelo processo de evapotranspiração. Em dezembro o saldo médio foi de $15,88 \mathrm{MJ} \cdot \mathrm{m}^{-2} \cdot \mathrm{d}^{-1}$ e apenas $46 \%$ foi utilizado para tal fim.

Cunha et al. (1996) construíram psicrômetros constituídos de pares termo-elétricos de cobre-constantan sendo um seco (exposto ao ambiente) e o outro úmido (envolto por algodão umedecido) e os utilizaram no estudo do balanço de energia e da razão de Bowen na cultura de milho, a céu aberto, e chegaram as seguintes conclusões: a demanda da energia para o fluxo de calor latente de evaporação superou a demanda para o fluxo de calor sensível na atmosfera, aumentando a diferença entre ambos com o desenvolvimento da cultura; o saldo de radiação foi utilizado, em proporções médias, para o ciclo de desenvolvimento, em $80 \%$ na forma de fluxo de calor latente de evaporação, $14 \%$ na forma de fluxo de calor sensível na atmosfera e $6 \%$ na forma de fluxo de calor no solo; a transferência de calor no solo acompanhou a disponibilidade energética na superfície, representada pelo saldo de radiação; e 
finalmente verificou-se que a magnitude do fluxo de calor no solo e o índice de área foliar da cultura apresentaram uma relação inversa. Oliveira et al. (1997), também utilizando instrumental semelhante ao construído por Cunha et al. (1996), analisaram os componentes do balanço de energia sobre um cultivo de amendoim irrigado a céu aberto e concluíram que 93,2 $\%$ da radiação disponível sobre a cultura foi utilizada para o fluxo de calor latente e 1,1\% para aquecimento do solo. O fluxo de calor sensível no ar contribuiu, para o fluxo de calor latente, com 5,7 \%, originário da advecção. Já Fontana et al. (1991) observaram em cultivo de soja que o fluxo de calor latente consumiu uma maior porção da radiação líquida, 95 \%, quando cultivado em área irrigada, sendo este percentual reduzido para 78 \% na parcela não irrigada. Bremer \& Ham (1999) concluíram que técnicas diferenciadas de cultivo de capim nativo afetaram os componentes do balanço de energia. Segundo os autores, em 44 dias observados, na área em que o capim foi inicialmente queimado a radiação líquida apresentou um acréscimo médio diário de 8,6 \% possibilitando maiores valores médios diários do fluxo de calor latente de evapotranspiração, em relação a área que não foi queimada.

Grant (1975) estimou a evapotranspiração da cevada pelos métodos da razão de Bowen, balanço de energia e aerodinâmico, comparando-as com as medidas por meio de lisímetro de pesagem, tendo chegado à conclusão que o melhor método de estimativa da evapotranspiração diária foi o da razão de Bowen. Já Green et al. (1984) comparando, na Nova Zelândia, a evapotranspiração de pastagem medida em lisímetro de pesagem e obtida através do método da razão de Bowen chegou às seguintes conclusões: os valores medidos e estimados apresentaram boa concordância no total diário evapotranspirado em dias sem chuvas. Ainda, quando os dias chuvosos foram considerados aumentou a discrepância entre os dados.

Apesar do largo emprego do método do balanço de energia alguns autores têm relatado problemas com o método (Daamen et al., 1999; Ibanez et al., 1999). O método da razão de Bowen deve ter seu uso limitado ao período diurno (Heilman \& Brittin, 1989; Cellier e Olioso, 1993; Kustas et al., 1996). Um ponto vulnerável do método é quando da aproximação da razão de Bowen do valor -1,0. Clothier et al. (1982) aconselharam, visando 
uma maior eficiência do método, descartar os valores menores que $-0,5$ devido a inconsistência dos mesmos. Ortega-Farias et al. (1996) recomendaram descartar valores inferiores a $-0,75$. Unland et al. (1996) aconselharam descartar os valores na faixa de $-0,7$ a -1,3. Para Perez et al. (1999) a faixa de descarte de dados deve ser variável com a acurácia do sensor, sendo tanto mais próxima de $-1,0$ quanto maior for a acurácia do instrumento de medida. Afirmaram ainda que, devem ser descartados valores negativos da razão de Bowen, originários de ocorrência de condensação (fluxos positivos do calor latente de evapotranspiração), quando $\mathrm{Rn}-\mathrm{G}>0$.

Para Howell et al. (1991) o método da razão de Bowen produz bons resultados na estimativa da evapotranspiração em escalas menores, como um dia, mas não são recomendados para períodos muito grande. Para Blad \& Rosemberg (1974), em condições de advecção, o método do balanço de energia pode superestimar em até $20 \%$ as medidas lisimétricas. Ressaltaram, ainda, que comumente próximo ao nascer e pôr-do-sol ocorrem valores elevados da razão de Bowen devido a dificuldade de se obter gradientes de temperatura e pressão de vapor d'água. Para Angus \& Watts (1984) o método do balanço de energia somente proporciona bons resultados em solos úmidos. Relataram, ainda, que em solos secos ou com consideráveis contribuições advectivas o modelo necessita de ajustes. Os autores propuseram, ainda, um modelo de ajuste dos dados para estas condições.

Com o sistema automático da razão de Bowen (Bowen ratio system), é possível registrar instantaneamente a radiação líquida, o fluxo de calor no solo e gradientes de pressão de vapor d'água e temperatura do ar, em duas alturas, permitindo a estimativa do balanço de radiação e, consequentemente, da evapotranspiração. O referido aparelho já foi testado em campo, tendo estimado adequadamente a evapotranspiração (Tanner et al., 1987; Nie et al., 1992). Em muitos trabalhos a evapotranspiração obtida pelo sistema razão de Bowen foi utilizada como valor padrão para diversos fins (Malek \& Binghan, 1993; Allen et al., 1994; Bland et al. 1996; Malek et al. 1997; Rosset et al., 1997). Em outros, como referência para a avaliação de outros métodos de estimativa da evapotranspiração (Malek \& Binghan, 1993; Kjelgaard et al. 1994; Baselga \& Allen, 1996; Hatfield et al., 1996; Jara et al., 1998). 
Kjelgaard et al. (1994) compararam a evapotranspiração de cultivo do milho obtida com o sistema automático de razão de Bowen (SARB) com a estimada por meio da equação de Penman-Monteith e com uma equação modificada do balanço de energia, pela inclusão da temperatura do dossel no cálculo do fluxo de calor sensível. Os autores concluíram que, em média, os dois modelos superestimaram de 10 a $13 \%$ os valores obtidos no sistema razão de Bowen. Também utilizando um sistema automático de razão de Bowen, Sauer et. al. (1998) obtiveram as seguintes conclusões, em solo com baixa umidade e cultivado com milho: nos dias nublados os valores médios diários da razão de Bowen foram menores que 1,5 e de 42 a 75\% da energia disponível foi consumida com a evapotranspiração; nos dias ensolarados os valores médios diários da razão de Bowen foram superiores a 2,3 e menos de $21 \%$ da energia disponível foi consumida pela evapotranspiração. Quando o solo foi umedecido os valores médios diários da razão de Bowen foram inferiores a 1,5 nos dias ensolarados e oscilaram de 0,87 a 1,84 nos dias nublados. Utilizando, também, sistemas automáticos da razão de Bowen, Malek \& Binghan (1997) analisaram a partição do saldo de radiação (Rn) no deserto de Nevada, EUA. Concluíram que, em média, a referida partição ao longo do ano foi de $85,3 \%$ para o fluxo de calor sensível no ar (H), 14,6\% para o fluxo de calor latente de evapotranspiração (LE) e 0,1\% para o fluxo de calor sensível no solo (G).

Perez et al. (1999) estudaram o descarte de valores inconsistentes da razão de Bowen, com o SARB, visando o aprimoramento do referido método. Os autores relataram que os dados inconsistentes apareceram, principalmente, ao nascer e pôr-do-sol, com Rn negativo, e à noite devido à inversão térmica. Uma outra fonte de ocorrência de erros foi o registro de LE > 0 (condensação), em períodos com $\mathrm{Rn}-\mathrm{G}>0$. Afirmaram que isso ocorreu, normalmente, nos momentos com baixos fluxos de calor latente (0 a $0,432 \mathrm{MJ} \cdot \mathrm{m}^{-2} \cdot \mathrm{d}^{-1}$, geralmente no início da manhã ou no final da tarde) e sob baixa advecção. Ainda segundo esses autores, um outro problema foi o baixo gradiente de vapor d'água (menores que 0,03 $\mathrm{kPa} \cdot \mathrm{m}^{-1}$ ) originários de fraca advecção, chuvas ou irrigação. Nessas condições, ocorreram LE $>0$ e valores da razão de Bowen próximos a -1,0. Os autores concluíram, ainda, que devem 
ser rejeitados os dados noturnos e obtidos após precipitação ou irrigação e que a ocorrência de gradientes de vapor d'água muito pequenos afeta a consistência das estimativas do SARB.

No Brasil, a utilização do sistema automático de razão de Bowen é recente. O SARB foi avaliado por Azevedo (1999) que comparou a evapotranspiração de referência estimada pelo mesmo com a medida por um lisímetro de pesagem e chegou as seguintes conclusões: o sistema automático da razão de Bowen estimou adequadamente a evapotranspiração de referência tanto na escala diária como na horária, apresentou pequena necessidade de manutenção e fácil manuseio. $\mathrm{O}$ autor recomendou-o para diversos estudos em substituição aos lisímetros devido à baixíssima mobilidade dos últimos em campo. Silva (2000) comparou a evapotranspiração de cultivo do feijão medida em lisímetro de pesagem e estimada pelo sistema razão de Bowen encontrando boa concordância entre os dados. Entretanto, ressaltou que apesar da boa concordância o sistema subestimou a evapotranspiração medida pelo lisímetro de pesagem.

Vários autores têm avaliado os sistemas automatizados alternativos, de menor custo, para determinação da razão de Bowen e obtido bons resultados (Ashktorab et al., 1989; Dugas et al., 1991; Cellier \& Olioso, 1993; Ashktorab et al., 1994; Frangi et al., 1996). Prueger et al. (1997) comparou os dados obtidos com um sistema simplificado de determinação da razão de Bowen, no qual não havia alternância entre os fluxos de ar originários dos dois níveis e sim dois psicrômetros, com os medidos por um lisímetro de pesagem. $\mathrm{O}$ autor concluiu que os dados medidos e estimados apresentaram boa concordância e, normalmente, diferiram em menos de $10 \%$.

Bausch \& Bernard (1992) realizaram estimativas do calor latente de evapotranspiração empregando um sistema automático de razão de Bowen (SARB) com movimentação lateral dos braços, possibilitando realizar medidas psicrométricas com variações temporais e espaciais. Os resultados dos testes mostraram, que o SARB construído estimava adequadamente a evapotranspiração, constituindo-se, também, em uma alternativa prática para substituir os lisímetros, e com a vantagem de maior mobilidade e apresentar menores custos. 


\section{IRRADIÂNCIA SOLAR GLOBAL E O SALDO DE RADIAÇÃO MEDIDAS EM GRAMA BATATAIS (Paspalum notatum flugge) E CAPIM TANZÂNIA (Panicum maximum Jacq), EM PIRACICABA, SP}

\section{Resumo}

Diversos modelos meteorológicos utilizados para estimar a evapotranspiração de culturas requerem informações a respeito do saldo de radiação. A radiação líquida ou saldo de radiação muitas vezes não é medida diretamente em razão do custo do sensor e operacionalidade. O objetivo deste trabalho foi avaliar as relações entre a irradiância solar global e a radiação líquida sobre superfícies vegetadas com capim tânzania (Panicum maximum Jacq.) e com grama batatais (Paspalum notatum flugge). O experimento foi conduzido em Piracicaba, estado de São Paulo, entre os dias 10 de maio de 2000 e 09 de junho de 2001. O período de coleta de dados foi dividido em 11 ciclos de trinta e seis dias, totalizando 396 dias de coleta de dados. Medidas de irradiância solar global (Qg) e radiação líquida $(\mathrm{Rn})$ foram feitas sobre grama batatais e capim tanzânia. Regressões entre radiação líquida e a irradiância solar global foram estimados, obtendo $\mathrm{Rn}=0,5418 \cdot \mathrm{Qg}\left(\mathrm{r}^{2}=0,9297\right)$ para uma superfície gramada e $\mathrm{Rn}=0,5613 \cdot \mathrm{Qg}\left(\mathrm{r}^{2}=0,8719\right)$ para uma superfície vegetada com o capim tanzânia. A radiação líquida disponível para superfície gramada foi inferior à energia disponível para a superfície cultivada com o capim tanzânia. O estabelecimento das relações apresentadas neste trabalho, mostra que o saldo de radiação em superfície gramada, assim como sobre o capim tanzânia, podem ser estimados satisfatoriamente a partir da irradiância solar global, sendo necessário, para isso, considerar suas variações sazonais.

\section{Summary}

The majority of the meteorological methods used to estimate crop evapotranspiration need the net radiation as an input. Instruments that measure net radiation directly are costly, 
thus most of the times it is obtained indirectly. The objective of this work was to evaluate the relationships between global solar irradiance and net radiation, for surfaces covered with Bahia grass (Paspalum notatum Flugge) and Guinea grass (Panicum maximum Jacq.). The experiment was conducted in Piracicaba, SP, Brazil, between May 10, 2000, and June 9, 2001. Data were collected in eleven periods of 36 days, yielding a total of 396 days. Measurements of global solar irradiance $(\mathrm{Qg})$ and net radiation $(\mathrm{Rn})$ were taken over Bahia grass and Guinea grass. The regression results between net radiation and global solar irradiance for these ground covers were: $\mathrm{Rn}=0,5418 . \mathrm{Qg}\left(\mathrm{r}^{2}=0,9297\right)$ for the Bahia grass, and $\mathrm{Rn}=0,5613 . \mathrm{Qg}\left(\mathrm{r}^{2}=0,8719\right)$ for the Guinea grass. The available net radiation for the Bahia grass was lower than that for Guinea grass. The results presented in this paper show that net irradiance can be satisfactorily estimated from global solar irradiance for both the Bahia grass and the Guinea grass. However, it is necessary to consider the variations in these relationships for the different seasons of the year.

\subsection{Introdução}

A energia solar é a fonte primária de energia responsável por todos os processos físicos naturais. Nos processos de transpiração das culturas e da evaporação da água do solo, que conjuntamente denominamos evapotranspiração, a radiação solar é a principal forma de energia condicionante destes processos. A radiação líquida ou saldo de radiação (Rn) sobre uma superfície vegetada é soma algébrica de todos os fluxos radiantes de onda curta e de onda longa que sobre ela incidem. A radiação líquida é o elemento mais importante usado em modelos meteorológicos de estimativa da evapotranspiração como Penman (1948) e no método da razão de Bowen (Tanner, 1960; Bergamaschi et al., 1988).

A radiação líquida $(\mathrm{Rn})$ é a principal fonte de energia para os diversos processos naturais, entre os quais o aquecimento do ar (fluxo de calor sensível), o aquecimento do solo (fluxo de calor no solo), a transpiração e evaporação (fluxo de calor latente), o aquecimento dos vegetais e também a fotossíntese. 
A radiação líquida varia temporal e espacialmente, dependendo das características ópticas da superfície, de acordo com seu coeficiente de reflexão (albedo), da irradiância solar global e das condições de temperatura e umidade da superfície e do ar. Sua mensuração direta é obtida pelo saldo-radiômetro, sensor que integra os balanços de ondas curtas e longas. Devido ao alto custo do sensor e sua rápida deterioração em relação a outros equipamentos meteorológicos, esta medida é dificilmente realizada, tanto nas estações meteorológicas convencionais como nas automáticas. De acordo com Llasat \& Zinder (1998), o sensor de radiação líquida é talvez o mais delicado de todos os sensores utilizados em estações meteorológicas. Apesar de serem calibrados anualmente e sofrerem manutenções periódicas é comum a ocorrência de diferenças acima de $10 \%$ entre valores calibrados e mensurados em campo.

A estimativa da Rn, para superfícies planas, pode ser realizada a partir da associação das equações de Angströn-Prescott, para o balanço de ondas curtas, e de Brunt, para o balanço de ondas longas, sendo esse procedimento recomendado pela FAO, quando o objetivo é a estimativa da evapotranspiração de referência por Penman-Monteith a partir de dados de estações meteorológicas convencionais (Allen et al., 1998; Pereira et al., 1998). Para tal estimativa são necessários dados de insolação, de pressão de vapor e de temperatura do ar (Sentelhas \& Nascimento, 2001). Além disso, a Rn pode ser estimada a partir de outras relações empíricas, como as apresentadas por Ometto (1968), Lloyd et al. (1988), Pereira et al. (1997) e Schöffel \& Volpe (2000).

A irradiância solar global que penetra na atmosfera e atinge a superfície da terra depende principalmente da turbidez atmosférica, da cobertura de nuvem e da topografia. Essa energia, ao atravessar a atmosfera, tem parte refletida pelas nuvens, parte espalhada pelas moléculas e partículas do ar e parte absorvida pelo vapor de água, dióxido de carbono, ozônio e compostos nitrosos. A porção absorvida aumenta a temperatura do ar e por conseguinte aumenta a emissão de ondas longas para a superfície da terra e para o espaço. O balanço de radiação representa, em última análise, as fontes e sumidouros de energia que afetam as condições meteorológicas e o clima do planeta (Souza \& Escobedo, 1997). 
Entretanto, a irradiância solar global, é medida na maioria das estações meteorológicas e para a maioria das localidades. Assim sendo, segundo Pereira et al. (1998) a Rn pode ser expressa exclusivamente em função da irradiância solar global $(\mathrm{Qg})$, sendo insignificante os desvios em relação aos outros métodos de estimativas. Os autores recomendam a utilização dessa relação quando da ausência do saldo-radiômetro .

Comparando dados meteorológicos obtidos concomitantemente por uma estação meteorológica convencional e uma automática, Sentelhas (1998) desenvolveu, testou e validou diversos modelos de regressão linear de estimativa da radiação líquida a partir de diferentes elementos meteorológicos. Para dados da estação meteorológica automática, essa estimativa pode ser obtida a partir da irradiância solar global, com a relação $\mathrm{Rn}=0,574 . \mathrm{Qg}\left(\mathrm{r}^{2}=\right.$ $0,9073)$.

A radiação líquida é extremamente correlacionada com a irradiância solar global. Shaw (1956) relatou um coeficiente de correlação entre valores de radiação líquida e irradiância solar global para o período de luz sobre superfície gramada de aproximadamente 0,98 em dias claros e 0,97 em dias encobertos. Esta correlação não pode ser aplicada para outras culturas. Decker (1959) afirmou que a radiação líquida aumenta com o incremento da altura da cobertura vegetal.

Estimativas reais de radiação líquida sobre superfícies naturais como solo nu, gramado, culturas anuais e perenes são importantes para determinação da energia disponível para os processos de transferência de calor sensível e latente entre a superfície e a atmosfera.

Existem poucos estudos sobre radiações obtidas em superfícies cultivadas com pastagens, principalmente quando nesta atividade agrícola se utiliza a irrigação. Por isso, desenvolveutse este trabalho com o objetivo de avaliar as relações entre a irradiância solar global e a radiação líquida sobre superfícies vegetadas com capim tânzania (Panicum maximum Jacq.) e com grama batatais (Paspalum notatum flugge). 


\subsection{Material e Métodos}

O trabalho foi conduzido na área experimental de irrigação do Departamento de Engenharia Rural da Escola Superior de Agricultura "Luiz de Queiroz", ESALQ/USP, situada na fazenda Areão, no município de Piracicaba, SP. O local apresenta como coordenadas geográficas $22^{\circ} 42^{\prime} 30^{\prime \prime}$ de latitude Sul, $47^{\circ} 30^{\prime}$ 00" de longitude Oeste; e aproximadamente 576 metros de altitude. O solo possui uma declividade aproximada de $2 \%$ e é classificado como argissolo vermelho (EMBRAPA, 1999), com horizonte A de textura argilosa (média de $45 \%$ de argila) e profundidade média de $0,30 \mathrm{~m}$.

O clima de Piracicaba é Cwa, ou seja, subtropical úmido conforme a classificação de Köepen, com verão chuvoso e inverno seco, sendo de $1250 \mathrm{~mm}$ a precipitação média anual. As temperaturas médias mensais variam de $24,8{ }^{\circ} \mathrm{C}$ no verão a $17,1{ }^{\circ} \mathrm{C}$ no inverno, com média anual de $21,4^{\circ} \mathrm{C}$.

O presente trabalho foi realizado no período de 10 de maio de 2000 a 09 de junho de 2001, totalizando 396 dias de coleta de dados.

Foram obtidos dados de irradiância solar global $(\mathrm{Qg})$ e radiação líquida no posto agrometeorológico (Rn grama), cultivado com grama batatais (Paspalum notatum flugge), na área experimental do Departamento de Engenharia Rural. A radiação líquida (Rn capim) também foi obtida em uma superfície cultivada com capim tanzânia (Panicum maximum Jacq.). O capim tanzânia foi instalado em uma área de $63.000 \mathrm{~m}^{2}$, distante 200 metros do posto agrometeorológico.

As medidas de irradiância solar global foram obtidas por meio de um piranômetro, modelo LI200X, fabricado pela Licor e radiação líquida por meio de saldo-radiômetros, modelo Q-7.1 Net Radiometer-REBS; espectro de 0,25 a 0,60 $\mu \mathrm{m}$, posicionados a um metro de altura acima das superfícies vegetadas. Estas medidas foram coletadas e armazenadas por sistemas de aquisição de dados (Campbell Scientific Datalogger 21X). O registro dos dados foi realizado a cada segundo e foram armazenadas médias a cada vinte minutos. 
O posto agrometeorológico foi irrigado freqüentemente por um sistema de aspersão convencional, a fim de se manter as condições de umidade do solo ideais a evapotranspiração de referência.

A área cultivada com capim tanzânia foi irrigada por um sistema de aspersão tipo pivôcentral. A irrigação foi realizada a cada seis dias, quando necessária, sendo que o volume de água aplicado foi determinado pela diferença entre as leituras de evapotranspiração obtidas por um lisímetro de pesagem cultivado com capim tanzânia e a precipitação ocorrida no período. A precipitação foi obtida por meio de um pluviógrafo instalado no posto agrometeorológico.

A área cultivada com capim tanzânia foi dividida em trinta e seis parcelas e pastejada por gado da raça Nelore, sendo que o gado permanecia um dia em cada parcela, perfazendo um ciclo de 36 dias entre pastejos. O pastejo resultava em uma cobertura residual de $0,40 \mathrm{~m}$ de altura.

As mensurações da irradiância solar global $(\mathrm{Qg})$, radiação líquida sobre superfície cultivada com grama batatais (Rn grama) e radiação líquida sobre superfície cultivada com capim tanzânia (Rn capim) foram realizadas durante 11 ciclos de trinta e seis dias. Esta divisão em ciclos teve a finalidade de caracterizar os intervalos entre pastejos.

Os dados de irradiância solar global e radiação líquida, estimados e medidos, foram correlacionados utilizando planilha eletrônica, constituindo gráficos do tipo dispersão com os respectivos coeficientes de correlação e equação de regressão linear. A metodologia utilizada para comparação dos valores medidos e estimados de radiação líquida fundamentou-se no coeficiente de determinação $\left(\mathrm{r}^{2}\right)$ e no erro padrão da estimativa (SEE), este último calculado pela expressão:

$$
\mathrm{SEE}=\left(\frac{\sum(\mathrm{y}-\hat{\mathrm{y}})^{2}}{\mathrm{n}-1}\right)^{1 / 2}
$$

em que: 
$\mathrm{SEE}=$ erro padrão da estimativa, em MJ.m $\mathrm{m}^{-2} \cdot \mathrm{d}^{-1}$;

$\mathrm{y}=$ Rn medida, em MJ.m. ${ }^{-2} \cdot \mathrm{d}^{-1}$;

$\hat{y}=$ Rn estimada pelo modelo de regressão, em MJ.m ${ }^{-2} \cdot \mathrm{d}^{-1} ; \mathrm{e}$

$\mathrm{n}$ = número de observações.

O índice de área foliar do capim tanzânia foi determinado por meio do equipamento LI 2000 Area Meter fabricado pela empresa Licor, sendo que a coleta de dados foi realizada logo após o pastejo, e 6, 12, 18, 24, 30 e 36 dias pós pastejo.

\subsection{Resultados e Discussão}

Na Tabela 1 são apresentadas as equações de regressão linear para estimativa da radiação líquida obtida sobre capim tanzânia (Rn capim) e a radiação líquida obtida sobre grama batatais (Rn grama) em função da irradiância solar global $(\mathrm{Qg})$, tomando os valores como totais diários, para cada ciclo e para todo o período analisado. Para cada equação é apresentado o respectivo coeficiente de determinação $\left(\mathrm{r}^{2}\right)$. Pode-se observar que, a relação entre Rn capim e Qg variou ao longo dos ciclos, tendo valor máximo no ciclo 8 (17/01/01 21/02/01), quando atingiu 0,6544 (Figura 1(h)), e valor mínimo no ciclo 11 (05/05/01 09/06/01), quando atingiu 0,4919 (Figura 1(k)).

De acordo com observações feitas durante o experimento, verificou-se que, o período de maior crescimento do capim foi entre os ciclos 5 e 9, e a relação média neste período foi 0,5983, enquanto que no período de menor crescimento do capim, entre os ciclos 1 e 4 , e ainda nos ciclos 10 e 11, essa relação cai para 0,5150, o que está relacionado ao maior coeficiente de reflexão da superfície com capim tanzânia, haja visto que no período correspondente aos ciclos 1, 2, 3, 4, 10 e 11 (período seco), as chuvas representaram apenas 26,14\% das precipitações registradas no período entre os ciclos 5 e 9 (período chuvoso). Outro fator que tem grande relação com essa variação é a nebulosidade e a umidade do ar, 
observado por Lloyd et al. (1998), na região Amazônica, e por Pereira et al. (1998), na região de Piracicaba, SP, o que interfere no balanço de ondas.

Tabela 1. Equações de regressão linear de estimativa da radiação líquida sobre superfície cultivada com capim tanzânia ( $\mathrm{Rn}$ capim) e superfície gramada ( $\mathrm{Rn}$ grama), expressas em $M J \cdot m^{-2} \cdot d^{-1}$, em função da irradiância solar global (Qg), em Piracicaba, SP.

\begin{tabular}{cccccc}
\hline Ciclo & Período & Rn capim & $\mathrm{r}^{2}$ & $\mathrm{Rn}$ grama & $\mathrm{r}^{2}$ \\
\hline 1 & $10 / 05 / 00-14 / 06 / 00$ & $\mathrm{Rn}=0,4967 . \mathrm{Qg}$ & 0,7677 & $\mathrm{Rn}=0,4767 . \mathrm{Qg}$ & 0,9425 \\
2 & $15 / 06 / 00-20 / 07 / 00$ & $\mathrm{Rn}=0,5208 . \mathrm{Qg}$ & 0,7822 & $\mathrm{Rn}=0,4989 . \mathrm{Qg}$ & 0,9089 \\
3 & $21 / 07 / 00-25 / 08 / 00$ & $\mathrm{Rn}=0,5281 . \mathrm{Qg}$ & 0,9155 & $\mathrm{Rn}=0,5036 . \mathrm{Qg}$ & 0,9611 \\
4 & $26 / 08 / 00-30 / 09 / 00$ & $\mathrm{Rn}=0,5270 . \mathrm{Qg}$ & 0,9098 & $\mathrm{Rn}=0,5045 . \mathrm{Qg}$ & 0,9297 \\
5 & $01 / 10 / 00-05 / 11 / 00$ & $\mathrm{Rn}=0,5593 . \mathrm{Qg}$ & 0,8251 & $\mathrm{Rn}=0,5393 \mathrm{Qg}$ & 0,9384 \\
6 & $06 / 11 / 00-11 / 12 / 00$ & $\mathrm{Rn}=0,6064 . \mathrm{Qg}$ & 0,9295 & $\mathrm{Rn}=0,5916 . \mathrm{Qg}$ & 0,9068 \\
7 & $12 / 12 / 00-16 / 01 / 01$ & $\mathrm{Rn}=0,6073 . \mathrm{Qg}$ & 0,8155 & $\mathrm{Rn}=0,5853 . \mathrm{Qg}$ & 0,9380 \\
8 & $17 / 01 / 01-21 / 02 / 01$ & $\mathrm{Rn}=0,6544 . \mathrm{Qg}$ & 0,8180 & $\mathrm{Rn}=0,5927 . \mathrm{Qg}$ & 0,9272 \\
9 & $22 / 02 / 01-29 / 03 / 01$ & $\mathrm{Rn}=0,5677 . \mathrm{Qg}$ & 0,7683 & $\mathrm{Rn}=0,5225 . \mathrm{Qg}$ & 0,9270 \\
10 & $30 / 03 / 01-04 / 05 / 01$ & $\mathrm{Rn}=0,5204 . \mathrm{Qg}$ & 0,7735 & $\mathrm{Rn}=0,5154 . \mathrm{Qg}$ & 0,9332 \\
11 & $05 / 05 / 01-09 / 06 / 01$ & $\mathrm{Rn}=0,4919 . \mathrm{Qg}$ & 0,9236 & $\mathrm{Rn}=0,4818 . \mathrm{Qg}$ & 0,9543 \\
$\mathbf{1 - 1 1}$ & $\mathbf{1 0 / 0 5 / 0 0 -}$ & $\mathbf{R n}=\mathbf{0 , 5 6 1 3 . Q g}$ & $\mathbf{0 , 8 7 1 9}$ & $\mathbf{R n}=\mathbf{0 , 5 4 1 8 . Q g}$ & $\mathbf{0 , 9 2 9 7}$ \\
& $\mathbf{0 9 / 0 6 / 0 1}$ & & & & \\
\hline
\end{tabular}

Verifica-se ainda, na Tabela 1, que a relação média entre Rn capim e Qg para todo o período analisado foi de 0,5613 , com o coeficiente de determinação, $\mathrm{r}^{2}=0,8719$ (Figura 1(1)), e para todo o período analisado a relação média entre Rn grama e Qg foi de 0,5418, com o coeficiente de determinação, $\mathrm{r}^{2}=0,9297$. Estes valores de $\mathrm{r}^{2}$, indicam haver uma relação linear entre os dois tipos de radiações.

O coeficiente angular da correlação entre a radiação líquida e a irradiância solar global para grama é relativamente menor do que a apresentada para superfície com capim tanzânia. 
Os baixos valores de SEE, obtidos para todo o período analisado, foram: $0,88 \mathrm{MJ} \cdot \mathrm{m}^{-2} \cdot \mathrm{d}^{-1}$ para a superfície com capim tanzânia e $0,48 \mathrm{MJ} \cdot \mathrm{m}^{-2} \cdot \mathrm{d}^{-1}$ para a superfície gramada, confirmando um ajuste satisfatório das equações de estimativa.

A Figura 1 mostra a dispersão entre radiação líquida sobre superfície cultivada com capim tanzânia (Rn capim) e a irradiância solar global (Qg), as equações de regressão linear e os coeficientes de determinação para cada ciclo, assim como para o período completo de observação, ciclo 1 até ciclo 11. Para uma melhor visualização da correlação entre as radiações, o coeficiente angular da equação de regressão foi forçado pela origem.

A mesma variação verificada entre $\mathrm{Rn}$ capim e $\mathrm{Qg}$, também foi observada para a relação entre Rn grama e Qg, porém com valores inferiores, sendo que o valor mínimo, igual a 0,4767, ocorreu no ciclo 1 (Figura 2(a)) e o máximo, igual a 0,5927 , ocorreu no ciclo 8 (Figura 2(b)). Segundo Sentelhas \& Nascimento (2001), para um período de aproximadamente 4 anos, a relação entre a radiação líquida sobre a grama e a irradiância solar global, obtidos em Piracicaba apresentou valor máximo de 0,595 para o mês de fevereiro e valor mínimo 0,473 para o mês de maio. Os valores encontrados neste trabalho, quando comparados com os encontrados por estes autores demonstram que, o período de coleta de dados não foi atípico em relação ao balanço de radiação sobre superfície cultivada com grama.

A Figura 2 mostra a dispersão entre radiação líquida sobre superfície cultivada com grama batatais (Rn grama) e a irradiância solar global $(\mathrm{Qg})$, as equações de regressão linear e os coeficientes de determinação para os ciclos 1 e 8, ciclos em que a relação $\mathrm{Rn}$ grama e Qg atingiram valores mínimos e máximos respectivamente. 

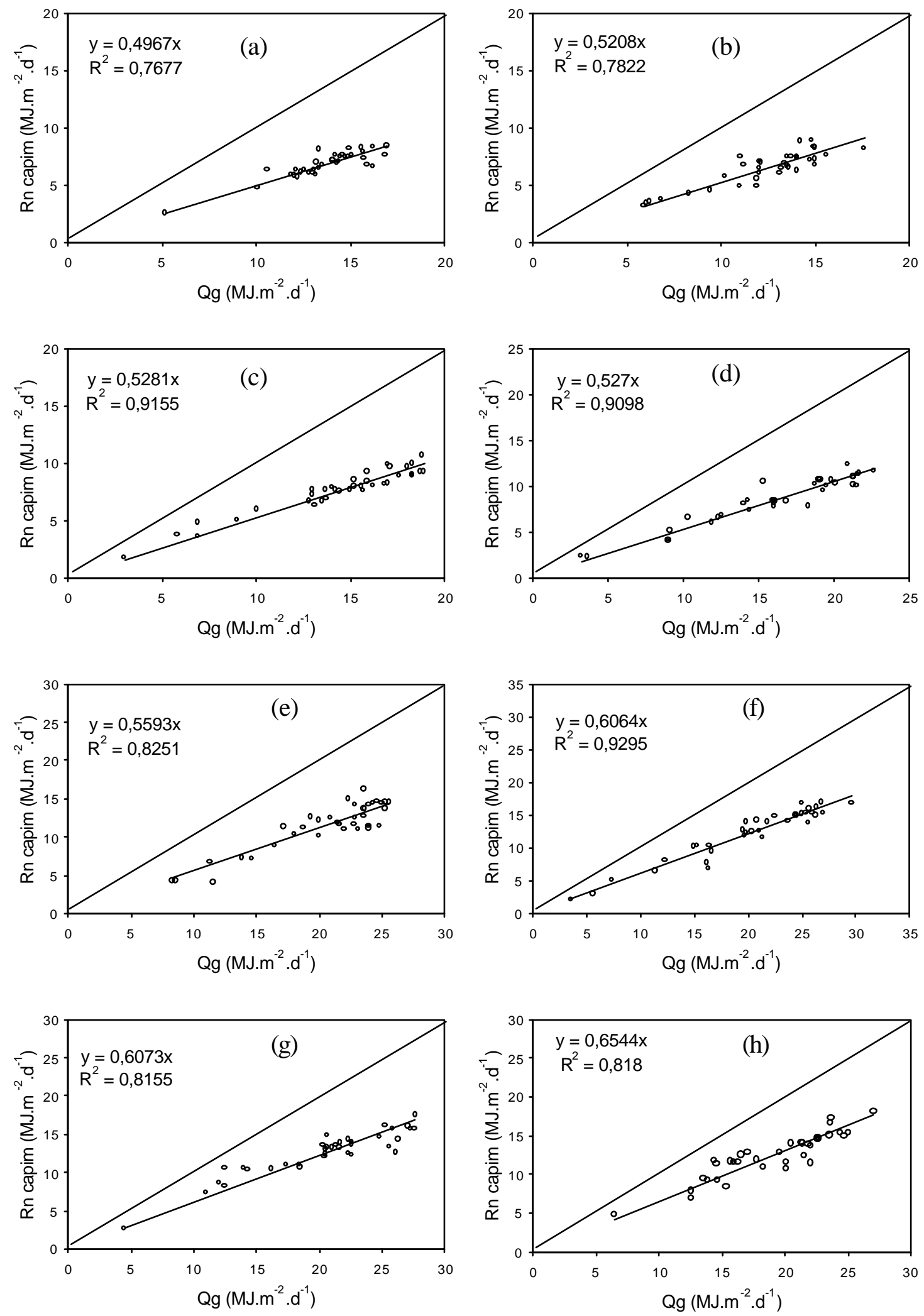

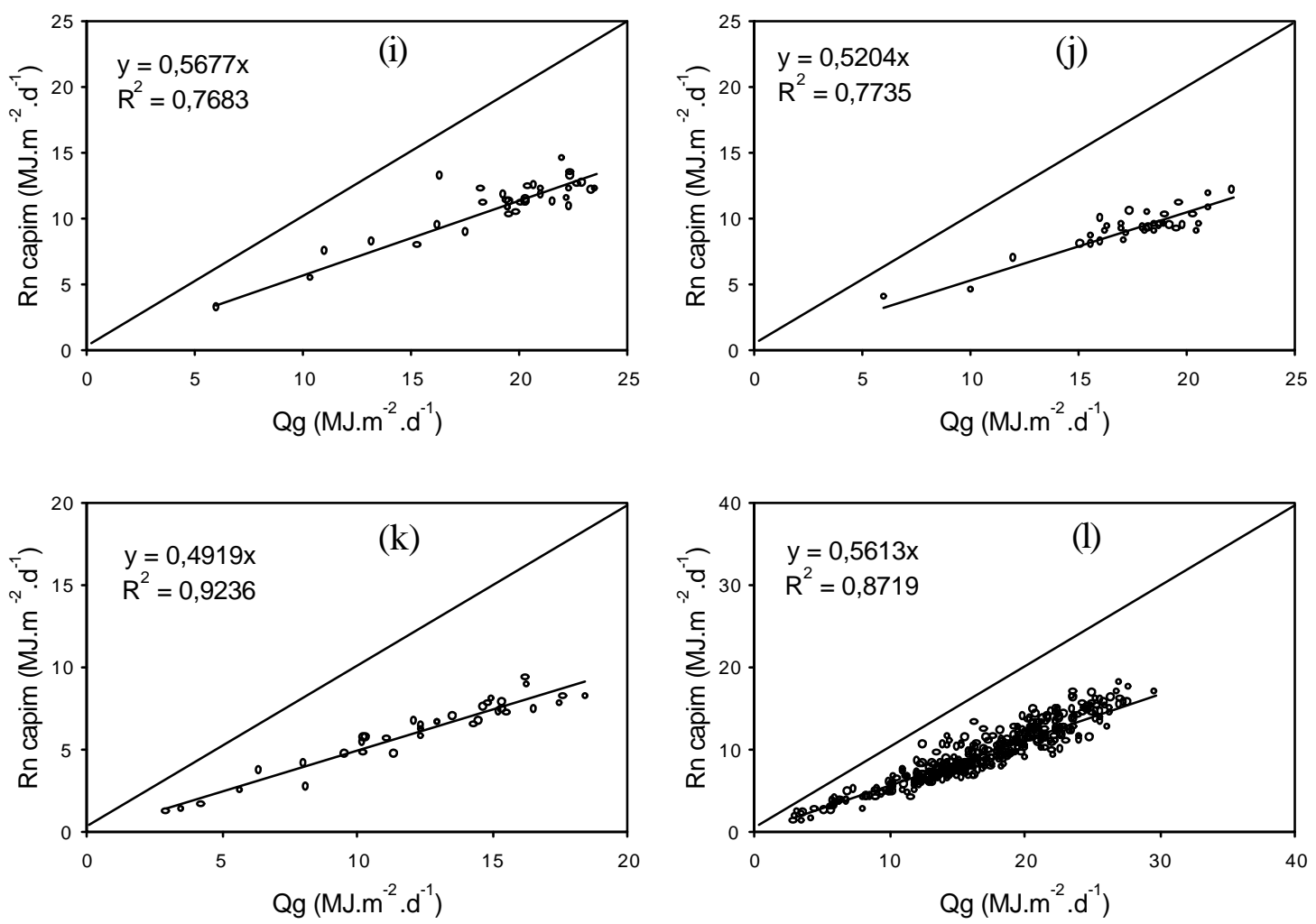

Figura 1 - Relação entre Rn capim e Qg para (a) ciclo 1, (b) ciclo 2, (c) ciclo 3, (d) ciclo 4, (e) ciclo 5, (f) ciclo 6, (g) ciclo 7, (h) ciclo 8, (i) ciclo 9, (j) ciclo 10, (k) ciclo 11, e (l) o período completo de coleta de dados, ciclo 1 até ciclo 11.
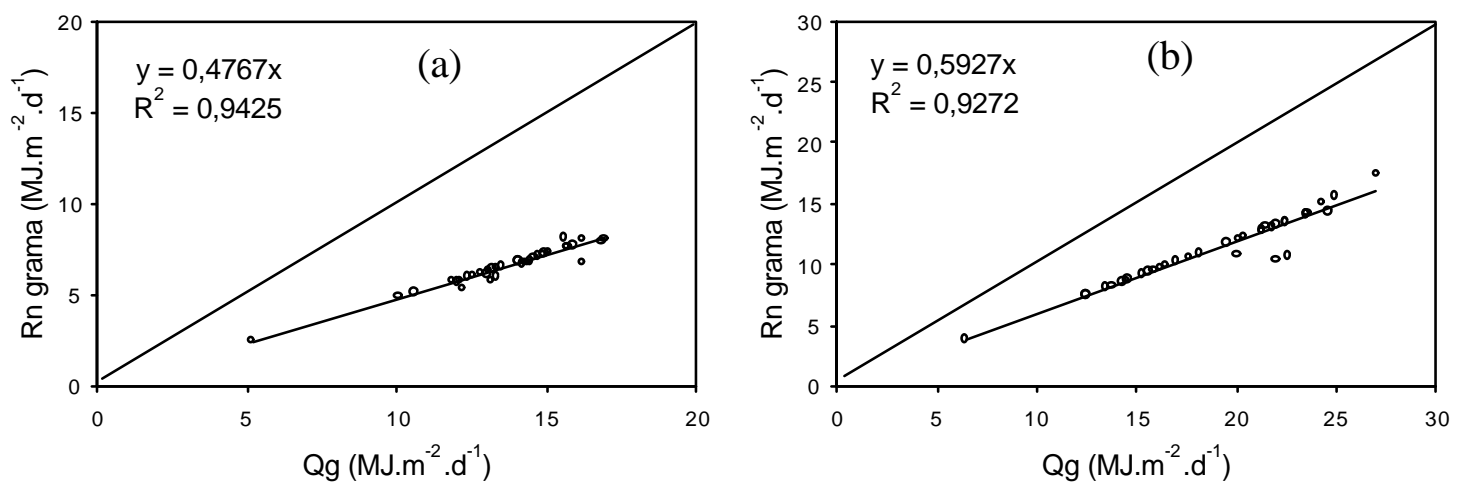

Figura 2 - Relação entre Rn grama e Qg para (a) ciclo 1, e (b) ciclo 8, em Piracicaba,SP. 
As Figuras 3 e 4 apresentam as curvas de variação da irradiância solar global e radiação líquida para as superfícies vegetadas por grama e capim tanzânia, respectivamente, para os ciclos 11 e 8 . As condições de cobertura do céu afetaram significativamente todos os componentes do balanço de radiação, inclusive irradiância solar global e a radiação líquida. Os dias com maior nebulosidade causaram uma diminuição em todos os componentes do balanço de radiação. Pode-se observar que no início do período analisado a radiação líquida sobre a grama é maior do que a quantidade de energia disponível sobre o capim tanzânia, este fato pode ser explicado pela diferença de reflexão da superfície cultivada com o capim ao longo dos ciclos. Após o pastejo o capim não cobre totalmente o solo, apresentando uma distribuição sobre a superfície em forma de touceiras, fato que pode ser evidenciado pelo índice de área foliar, que no início dos ciclos é menor que um (Figura 5(a) e 5(b)). O albedo da superfície vegetada com capim tanzânia é variável ao longo dos ciclos e também é diferente entre os ciclos.

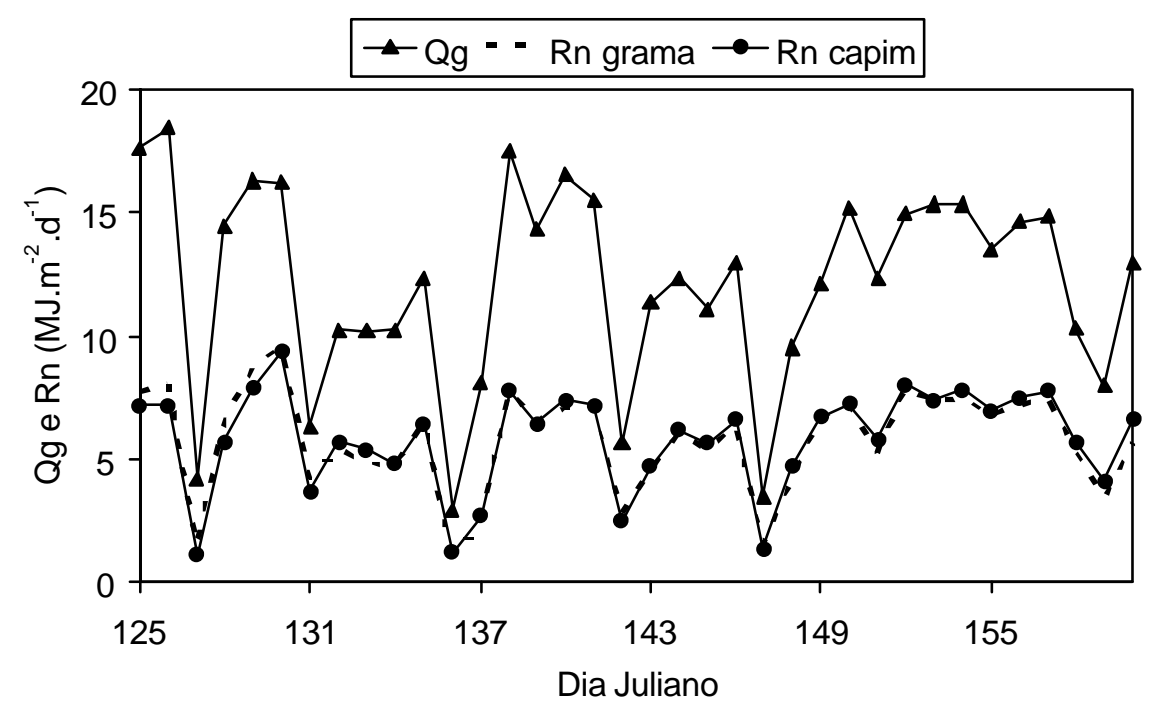

Figura 3 - Curvas de variação de irradiância solar global (Qg), radiação líquida (Rn capim) para superfície cultivada com capim tanzânia e radiação líquida ( $\mathrm{Rn}$ grama) vegetada por grama, para o ciclo 11, em Piracicaba, SP. 
Na Figura 3 nota-se que, a partir do sétimo dia após o pastejo (dia juliano 132) a radiação líquida sobre a grama torna-se menor do que a quantidade de energia disponível sobre o capim tanzânia, permanecendo assim durante a todo o restante do período de observação, porém a diferença entre os saldos de radiação é pequena. Esta pequena diferença, está relacionada com a pequena diferença entre os índices de área foliar da grama e do capim tanzânia.

Na Figura 4, observa-se o mesmo comportamento do início do ciclo 11, sendo que a partir do quinto dia após o pastejo (dia juliano 22), a radiação líquida sobre a grama é menor do que a quantidade de energia disponível sobre o capim tanzânia. Porém a medida que chega-se ao final do ciclo, a diferença entre os saldos de radiação aumenta. Este fato se deve ao aumento do índice de área foliar do capim tanzânia, que atingiu o seu máximo valor durante este ciclo, refletindo no aumento da radiação líquida.

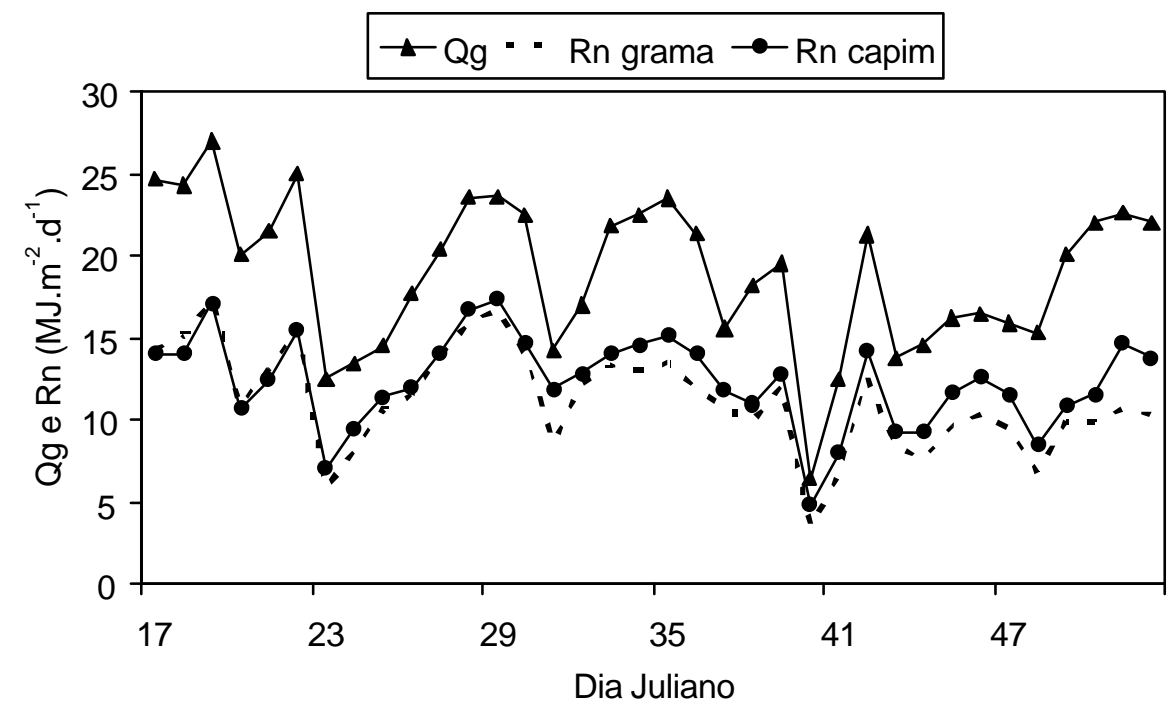

Figura 4 - Curvas de variação de irradiância solar global (Qg), radiação líquida (Rn capim) para superfície cultivada com capim tanzânia e radiação líquida (Rn grama) vegetada por grama, para o ciclo 8, em Piracicaba, SP. 
A Figura 5 mostra a variação do índice de área foliar (IAF) do capim tanzânia durante o ciclo 11 (Figura 5(a)) e no ciclo 8 (Figura 5(b)). Pode-se notar que, o IAF inicial correspondente a um resíduo após o pastejo de 0,40 m de altura para o capim tanzânia é de 0,15. Este valor baixo se deve à distribuição em touceiras do capim sobre a superfície do solo. O índice de área foliar máximo no ciclo 11 foi de 3,92, e no ciclo 8 foi de 7,30, caracterizando a estacionalidade de produção do capim na região de Piracicaba, SP.
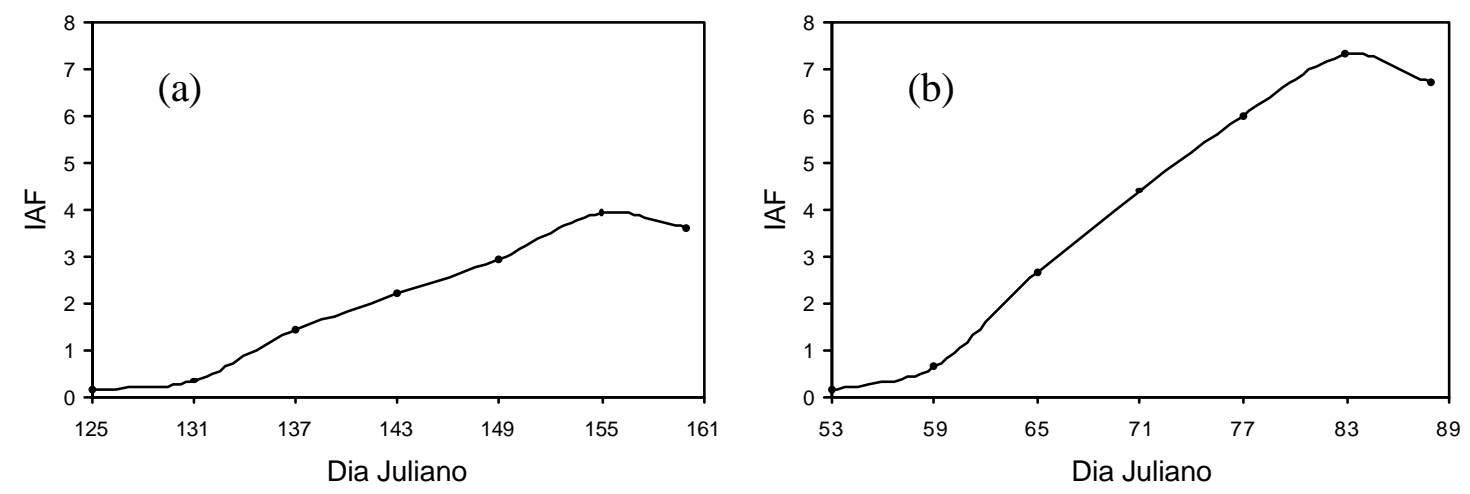

Figura 5 - Índice de área foliar (IAF) do capim tanzânia (a) no ciclo 11 e (b) no ciclo 8, em Piracicaba, SP.

O valor máximo de índice de área foliar medido no ciclo 8, foi também o maior valor obtido durante todo o período de coleta de dados.

\subsection{Conclusões}

O estabelecimento das relações apresentadas neste trabalho, mostra que o saldo de radiação em superfície gramada, assim como sobre o capim tanzânia, pode ser estimado satisfatoriamente a partir da irradiância solar global, com a necessidade de se considerar suas variações sazonais. 
A radiação líquida da superfície vegetada com capim tanzânia foi superior à radiação líquida disponível para um superfície gramada.

A relação entre $\mathrm{Rn}$ e $\mathrm{Qg}$ sobre a superfície vegetada com capim tanzânia cresceu com o aumento do índice de área foliar. 


\section{DESEMPENHO DE SISTEMAS AUTOMÁTICOS DE RAZÃo DE BOWEN SOBRE SUPERFÍCIE CULTIVADA COM GRAMA BATATAIS (Paspalum notatum flugge)}

\section{Resumo}

Diferentes métodos podem ser utilizados na determinação da evapotraspiração. Métodos meteorológicos de determinação da evapotranspiração das superfícies vegetadas, têm vantagens em relação a outros métodos, tais como lisímetros e métodos baseados na umidade do solo. Eles não requerem alterações da superfície, podem ser empregados com grande grau de mobilidade, podem ser usados para pequenos intervalos de tempo. Por isso, desenvolveu-se este trabalho com o objetivo de avaliar o desempenho de sistemas automáticos de razão de Bowen na estimativa da evapotranspiração de referência e comparar os valores estimados pelo balanço de energia com os estimados pelo modelo de PenmanMonteith e com os medidos em lisímetro de pesagem. $\mathrm{O}$ experimento foi conduzido em Piracicaba, estado de São Paulo entre os dias 11 a 25 de junho de 2000, totalizando 15 dias de coleta de dados. Foram obtidos dados de evapotranspiração em uma área de $10.000 \mathrm{~m}^{2}$ cultivado com grama batatais, na área experimental (posto agrometeorológico) do Departamento de Engenharia Rural. Foram utilizados dois sistemas automáticos de razão de Bowen (SARB), fabricado pela Campbell Scientific, e instalados no centro da área experimental. A medida direta da evapotranspiração de referência (ETo) foi obtida por meio de um lisímetro de pesagem, o qual era composto por três células de carga com capacidade de $1000 \mathrm{~kg}$ cada. A evapotranspiração média de referência estimada pelo SARB 1 foi de 3,50 mm.d $\mathrm{d}^{-1}$, ou 52,50 mm para o período de observação; a evapotranspiração média de referência estimada pelo SARB 2 foi de 3,44 $\mathrm{mm}^{-1}{ }^{-1}$, ou 51,62 $\mathrm{mm}$ para o período de observação; a evapotranspiração média de referência estimada pelo modelo de PenmanMonteith foi de 3,36 mm.d $\mathrm{d}^{-1}$, ou 50,40 mm para o período de observação e o valor de ETo mensurados pelo lisímetro de pesagem foi de $3,32 \mathrm{~mm} \cdot \mathrm{d}^{-1}$ ou 49,80 mm para o período de 
observação. As estimativas da evapotranspiração obtidas pelos sistemas automáticos de razão de Bowen superestimaram as determinações realizadas pelo lisímetro no período analisado. A estimativa da evapotranspiração apresentou uma excelente correlação entre os dois equipamentos de razão de Bowen no período analisado. Os sistemas automáticos de razão de Bowen apresentaram pequena necessidade de manutenção durante o período analisado.

\section{Summary}

Evapotranspiration determination with meteorological methods are more advantageous than the methods such as lysimeters and the methods based on soil moisture. Meteorological methods do not disturb the surface, the instruments can easily be moved and can be used for small intervals of time. The objectives of this work were: first to evaluate the Bowen ratio automated systems performance to estimate reference crop evapotranspiration; second, to compare the evapotranspiration estimated through the energy balance method, PenmanMonteith model and by the weighing lysimeter. The experiment was conducted in Piracicaba, SP, Brazil, between June 11 and June 25, 2000. Evapotranspiration data were obtained from an area of $10,000 \mathrm{~m}^{2}$ cultivated with Bahia grass, located in the Agrometeorological Station of the Rural Engineering Department of the Sao Paulo University at Piracicaba. Two Campbell Scientific automated Bowen ratio systems (ABRS) were installed at the center of the experimental area. The reference evapotranspiration (ETo) was measured using the weighing lysimeter, which had three loading cells with a capacity of $1,000 \mathrm{~kg}$ each. The average reference evapotranspiration estimated by the ABRS 1 was $3.50 \mathrm{~mm}^{-d a y}{ }^{-1}$, or $52.50 \mathrm{~mm}$ for the entire observation period; for the ABRS 2 estimated ETo was 3.44 mm.day $^{-1}$, or 51.62 $\mathrm{mm}$ for the entire observation period; for the Penman-Monteith model estimated ETo was 3.36 mm.day ${ }^{-1}$, or $50.40 \mathrm{~mm}$ for the entire observation period; the ETo values measured with the weighing lysimeter were $3.32 \mathrm{~mm} \cdot \mathrm{d}^{-1}$ or $49.80 \mathrm{~mm}$ for the entire observation period. For the analyzed period the automated Bowen ratio systems overestimated evapotranspiration as compared with the observations using the weighing lysimeter. A high correlation was obtained 
between the evapotranspiration estimated using the two automated Bowen ratio systems for the analyzed period. The automated Bowen ratio systems needed low maintenance during the period that observations were taken.

\subsection{Introdução}

Métodos meteorológicos de determinação da evapotranspiração das superfícies vegetadas, tem vantagens em relação a outros métodos, tais como lisímetros e métodos baseados na umidade do solo. Eles não requerem alterações da superfície, podem ser empregados com grande grau de mobilidade, podem ser usados para pequenos intervalos de tempo, e podem prover informações dos fluxos de calor sensível e fluxo de dióxido de carbono. Métodos meteorológicos também apresentam desvantagens. Eles requerem mensuramentos contínuos dos elementos meteorológicos necessários, alguns dos quais são de difícil determinação. Apesar disso as estações meteorológicas são capazes de suplantar a necessidade de aquisição de dados de uma maneira eficaz e com viabilidade econômica.

Bowen (1926) introduziu o conceito de razão de Bowen como sendo a relação entre o calor sensível de aquecimento do ar $(\mathrm{H})$ e o calor latente de evaporação da água (LE). Esta relação pode ser expressa como o produto da constante psicrométrica pela relação entre a variação de temperatura e a variação de pressão de vapor de água no ar.

O método da razão de Bowen tornou-se modelo de mensuração do fluxo de calor latente de evaporação da água e o fluxo de calor sensível de aquecimento do ar no balanço de energia. A validade do método foi verificada em diversos estudos (Tanner, 1960; Villa Nova, 1973; Sinclar et al. , 1975; Bergamaschi et al., 1988). Limitações do método da razão de Bowen ocorrem perto do nascer e pôr do sol, por causa dos pequenos gradientes de temperatura $(\mathrm{T})$ e pressão de vapor (e), que resultam em valores para a razão de Bowen $(\beta)$ aproximadamente -1 ou $\infty$. Limitações também podem ocorrer em culturas de coberturas não uniforme e outras condições adversas. 
O objetivo deste trabalho foi avaliar o desempenho de sistemas automáticos de razão de Bowen na estimativa da evapotranspiração de referência e comparar os valores estimados pelo balanço de energia com os estimados pelo modelo de Penman-Monteith e com os medidos em lisímetro de pesagem.

\subsection{Material e Métodos}

O trabalho foi conduzido na área experimental de irrigação do Departamento de Engenharia Rural da Escola Superior de Agricultura "Luiz de Queiroz”, ESALQ/USP, situada na fazenda Areão, no município de Piracicaba, SP. O local apresenta como coordenadas geográficas $22^{\circ} 42^{\prime} 30^{\prime \prime}$ de latitude Sul, $47^{\circ} 30^{\prime} 00^{\prime \prime}$ de longitude Oeste; e aproximadamente 576 metros de altitude. O solo possui uma declividade aproximada de $2 \%$ e é classificado como argissolo vermelho (EMBRAPA, 1999), com horizonte A de textura argilosa (média de $45 \%$ de argila) e profundidade média de $0,30 \mathrm{~m}$.

O clima de Piracicaba é Cwa, ou seja, subtropical úmido conforme a classificação de Köepen, com verão chuvoso e inverno seco, sendo de $1250 \mathrm{~mm}$ a precipitação média anual. As temperaturas médias mensais variam de $24,8{ }^{\circ} \mathrm{C}$ no verão a $17,1{ }^{\circ} \mathrm{C}$ no inverno, com média anual de $21,4^{\circ} \mathrm{C}$.

O presente trabalho foi realizado no período de 11 a 25 de junho de 2000, totalizando 15 dias de coleta de dados.

Foram obtidos dados de evapotranspiração em uma área de $10.000 \mathrm{~m}^{2}$ cultivado com grama batatais (Paspalum notatum flugge), na área experimental (posto agrometeorológico) do Departamento de Engenharia Rural. O posto agrometeorológico foi irrigado freqüentemente por um sistema de aspersão convencional, a fim de se manter as condições de umidade do solo ideais a evapotranspiração de referência.

A evapotranspiração de referência foi estimada de duas maneiras: pelo método do balanço de energia, por meio de dois sistemas automáticos de razão de Bowen e pelo modelo de Penman-Monteith. 
Foram utilizados dois sistemas automáticos de razão de Bowen (Campbell Scientific, Bowen ratio system), e instalados no centro da área experimental. Cada sistema automático de razão de Bowen foi conectado a um sistemas de aquisição de dados. Um sistema automático de razão de Bowen (SARB1) foi conectado a um datalogger 21X fabricado pela Campbell Scientific e o outro sistema automático de razão de Bowen (SARB2) conectado a um datalogger $23 \mathrm{X}$ fabricado pela mesma empresa. $\mathrm{O}$ registro dos dados foi realizado a cada dez segundos e foram armazenadas médias a cada vinte minutos. Os dados obtidos com o equipamento, são: radiação líquida $(\mathrm{Rn})$; fluxo de calor no solo, realizado em dois pontos $\left(\mathrm{G}_{1}\right.$ e $\mathrm{G}_{2}$ ); gradientes de temperatura e de tensão de vapor d'água do ar acima da superfície. A temperatura do ar $\left({ }^{\circ} \mathrm{C}\right)$ e a umidade absoluta $\left(\mathrm{kg} \cdot \mathrm{m}^{-3}\right)$ foram mensuradas nos níveis 0,10 e 1,50 $\mathrm{m}$ acima da superfície vegetada. A radiação líquida $\left(\mathrm{MJ} \cdot \mathrm{m}^{-2} \cdot \mathrm{d}^{-1}\right)$ foi mensurada a $1,00 \mathrm{~m}$ acima da superfície vegetada e os fluxos de calor no solo $\left(\mathrm{MJ}^{-2} \mathrm{~m}^{-2} \cdot \mathrm{d}^{-1}\right)$ foram mensurados a 0,08 m abaixo de superfície vegetada. A partir das medições de radiação líquida (Rn), fluxos de calor no solo $\left(\mathrm{G}_{1}\right.$ e $\left.\mathrm{G}_{2}\right)$, diferenças de temperatura $(\Delta \mathrm{T})$ e pressão de vapor $(\Delta \mathrm{e})$ entre dois níveis o balanço de energia pode ser apresentado como:

$$
\mathrm{Rn}-\mathrm{G}-\mathrm{H}-\mathrm{LE}=0
$$

De posse dos valores de gradientes de temperatura $(\Delta \mathrm{T})$, de gradientes de tensão do vapor d'água do ar $(\Delta \mathrm{e})$ e coeficiente psicrométrico $(\gamma)$ para o equipamento com ventilação forçada, efetuaram-se os cálculos, de forma a estimar o valor da razão de Bowen $(\beta)$, para cada intervalo de tempo correspondente a 20 minutos, conforme a equação (2).

$$
\beta=\gamma \frac{\Delta \mathrm{T}}{\Delta \mathrm{e}}
$$

em que:

$\gamma=$ coeficiente psicrométrico, igual a $0,0626 \mathrm{kPa} .{ }^{\circ} \mathrm{C}^{-1}$.

O valor do coeficiente psicrométrico foi obtido por meio da seguinte equação:

$$
\gamma=\frac{P \cdot c p}{\lambda \cdot \varepsilon}
$$

em que: 
$\mathrm{P}=$ pressão atmosférica, igual a 94,93 $\mathrm{kPa}$;

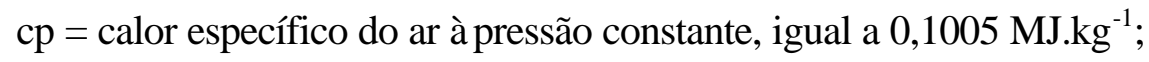

$\lambda=$ calor latente de evaporação, igual a 2,45 MJ. $\mathrm{kg}^{-1} ; \mathrm{e}$

$\varepsilon=$ razão entre a massa molecular do vapor d'água e a massa molecular do ar, igual a 0,622 .

$\mathrm{O}$ fluxo de calor latente, em MJ.m${ }^{-2} \cdot \mathrm{d}^{-1}$, foi estimado por meio da seguinte equação.

$\mathrm{LE}=\frac{\mathrm{Rn}-\left(\frac{\mathrm{G}_{1}+\mathrm{G}_{2}}{2}\right)}{(1+\beta)}$

Considerou-se como positivo o fluxo que fluía da atmosfera ou subsolo para a superfície, e negativo quando fluía da superfície para a atmosfera ou subsolo. Entretanto, matematicamente para que tais considerações fossem aplicadas corretamente, no cálculo do fluxo de calor latente, fez-se necessário adicionar o sinal de "negativo" junto ao saldo de radiação. Devido a convenção adotada, pelo SARB, fez-se também necessário adicionar o sinal "negativo" aos valores obtidos com os fluxos de calor no solo. Assim sendo, a equação (4) pode ser escrita da seguinte maneira.

$$
L E=\frac{-R n-\left(\frac{-G_{1}-G_{2}}{2}\right)}{(1+\beta)}
$$

Bowen (1926) relacionou os fluxos de calor sensível (H) e latente (LE), conforme equação abaixo, sendo a mesma conhecida como razão de Bowen $(\beta)$ e tendo sida amplamente utilizada na estimativa da evapotranspiração (Mastorilli et al., 1989; Fontana et al., 1991; Herbst et al., 1996; Steduto \& Hsiao, 1998).

$$
\beta=\frac{H}{L E}
$$

Após a estimativa da razão de Bowen para cada intervalo de tempo, e de posse dos valores da radiação líquida $(\mathrm{Rn})$ e dos fluxos de calor sensível no solo $\left(\mathrm{G}_{1}\right.$ e $\left.\mathrm{G}_{2}\right)$, obtidos com sensores automáticos, foi possível realizar a estimativa do fluxo de calor sensível, H, em MJ.m${ }^{2} \cdot d^{-1}$, (equação 7$)$. 


$$
\mathrm{H}=\beta . \mathrm{LE}
$$

Conhecidos todos os valores significativos dos componentes do balanço de energia foi possível calcular a estimativa da evapotranspiração de referência (ETo), em mm.20min ${ }^{-1}$, para cada intervalo de tempo de 20 minutos, em todo o período estudado.

$$
\mathrm{ETo}=\frac{\mathrm{LE}}{2,45 \cdot 72 \cdot \mathrm{t}}
$$

em que:

$\mathrm{t}=$ intervalo de tempo considerado, ou seja, 20 minutos ;

$72=$ constante utilizada para ajustar a escala de tempo; e

2,45 = constante utilizada para converter o fluxo de calor latente em água evapotranspirada.

Na estimativa de evapotranspiração de referência (ETo) consideram-se valores diários conforme recomendação de Heilman \& Brittin (1989), Cellier \& Olioso (1993) e Kustas et al. (1996). Foram também descartadas as estimativas de ETo originários de valores da razão de Bowen entre - 0,7 e - 1,3, conforme Uhland et al. (1996).

A estimativa da evapotranspiração de referência pelo modelo de Penman-Monteith foi obtida por meio de elementos meteorológicos fornecidos por uma estação meteorológica automática e aplicada na seguinte equação proposta por Monteith (1965):

$$
\mathrm{LE}=\frac{\mathrm{s} \cdot(\mathrm{Rn}-\mathrm{G})+\rho \cdot \mathrm{cp} \cdot \frac{\Delta \mathrm{e}}{\mathrm{ra}}}{\mathrm{s}+\gamma \cdot\left(1+\frac{\mathrm{rc}}{\mathrm{ra}}\right)}
$$

em que:

$$
\begin{aligned}
& \mathrm{LE}=\text { calor latente de evapotranspiração, em } \mathrm{MJ} \cdot \mathrm{m}^{-2} \cdot \mathrm{d}^{-1} \\
& \mathrm{Rn}=\text { radiação líquida, em MJ.m } \mathrm{m}^{-2} \cdot \mathrm{d}^{-1}
\end{aligned}
$$


$\mathrm{G}=$ fluxo de calor sensível no solo, em MJ.m. $\mathrm{m}^{-2} \mathrm{~d}^{-1}$;

$\rho=$ massa específica do ar atmosférico, $1,26 \mathrm{~kg} \cdot \mathrm{m}^{-3}$;

$\mathrm{C}_{\mathrm{p}}=$ calor específico do ar à pressão constante, $1,005 \mathrm{MJ} \cdot \mathrm{kg}^{-1} \cdot \mathrm{C}^{-1}$;

$\Delta \mathrm{e}=$ déficit de vapor d'água a temperatura do ar, es - ea, em $\mathrm{kPa}$;

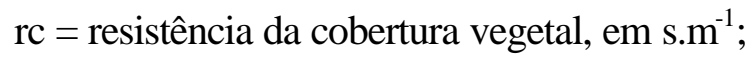

$\mathrm{ra}=$ resistência aerodinâmica à transferência de calor sensível e calor latente de evaporação, em s.m ${ }^{-1}$;

$\gamma=$ coeficiente psicrométrico, adotou-se $0,0626 \mathrm{kPa}^{\circ} \mathrm{C}^{-1}$;

$\mathrm{s}$ = inclinação da tangente à curva de pressão de saturação de vapor d'água, no ponto dado pela temperatura do ar, em $\mathrm{kPa} .{ }^{\circ} \mathrm{C}^{-1}$.

$\mathrm{O}$ valor da tangente à curva de pressão de saturação de vapor d'água, s, foi calculado pela equação (10):

$$
\mathrm{s}=\frac{4098 . \text { es }}{(\mathrm{T}+237,3)^{2}}
$$

em que:

es $=$ pressão de saturação do vapor d 'água, em $\mathrm{kPa}$, e

$\mathrm{T}=$ temperatura do ar, em ${ }^{\circ} \mathrm{C}$.

No calculo da pressão de saturação do vapor d'água, es em $\mathrm{kPa}$, foi utilizado a equação de Tetens:

es $=0,6108 \cdot 10\left(\frac{7,5 \cdot T}{237,3+T}\right)$

em que:

$\mathrm{T}=$ temperatura do ar, em ${ }^{\circ} \mathrm{C}$.

A pressão atual de vapor d'água, ea em $\mathrm{kPa}$, foi calculada pela equação (12):

$$
\text { ea }=\frac{\text { es . UR }}{100}
$$

em que:

$\mathrm{UR}=$ umidade relativa do ar, em \%. 
Assumiu-se, em concordância com a parametrização proposta pela FAO, a equação (13) para cálculo da resistência aerodinâmica, ra em s.m ${ }^{-1}$ :

$$
\mathrm{ra}=\frac{208}{\mathrm{u}_{2,0 \mathrm{~m}}}
$$

em que:

$\mathrm{u}_{2,0 \mathrm{~m}}=$ velocidade do vento à $2,0 \mathrm{~m}$ de altura.

Do mesmo modo, a relação entre a resistência da cobertura vegetal (rc) e a resistência aerodinâmica (ra); foi quantificada por meio da equação (14).

$$
\frac{\mathrm{rc}}{\mathrm{ra}} \cong 0,33 \cdot \mathrm{u}_{2,0 \mathrm{~m}}
$$

em que:

$$
\text { rc }=\text { resistência do dossel, em s.m } \mathrm{m}^{-1} \text {. }
$$

A medida direta da evapotranspiração de referência foi obtida por meio de um lisímetro de pesagem, o qual era composto por três células de carga com capacidade de 1000 $\mathrm{kg}$ cada. $\mathrm{O}$ lisímetro possui as seguintes dimensões: $0,70 \mathrm{~m}$ de profundidade, $1,00 \mathrm{~m}$ de comprimento e 1,00 m de largura.

Os valores de evapotranspiração obtidos pelo lisímetro foram considerados como padrão.

\subsection{Resultados e Discussão}


A Figura 1(a) mostra a equação de regressão e o coeficiente de determinação entre a estimativa da evapotranspiração de referência obtida pelo sistema automático de razão de Bowen 1 ( ETo SARB 1) e a estimativa da evapotranspiração obtida pelo sistema automático de razão de Bowen 2 (ETo SARB 2), para dados obtidos entre os dias 11 e 25 de junho de 2000. A Figura 1(b) mostra a equação de regressão e o coeficiente de determinação entre a estimativa da evapotranspiração de referência obtida pelo modelo de Penman-Monteith (ETo P-M) e a medida direta da evapotranspiração obtida por um lisímetro (ETo lisímetro), para dados obtidos entre os dias 11 e 25 de junho de 2000.
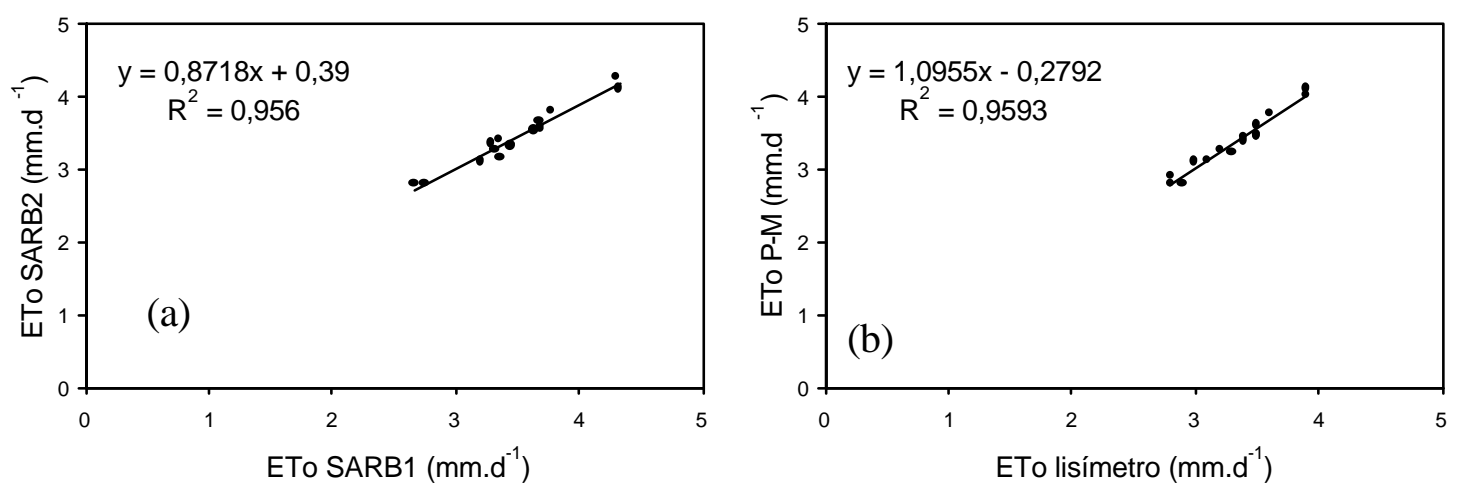

Figura 1 - Regressões entre os valores de Eto: (a) estimado por SARB 1 e SARB 2; e (b) estimado por Penman-Monteith (ETo P-M) e medido por lisímetro, nos dias 11 a 25 de junho de 2000, em Piracicaba, SP.

As equações de regressão das estimativas da evapotranspiração obtidas pelos sistemas automáticos de razão de Bowen (SARB 1 e SARB 2) comparadas com a determinação da evapotranspiração obtida pelo lisímetro de pesagem são apresentadas pelas Figuras 2(a) e 2(b), respectivamente. Os dados obtidos pelos SARB 1 e SARB 2 superestimaram as determinações realizadas pelo lisímetro no período analisado em 5,62 e 3,69\%, respectivamente. O modelo de Penman-Monteith superestimou as determinações realizadas pelo lisímetro no período analisado em apenas 1,23\%. 

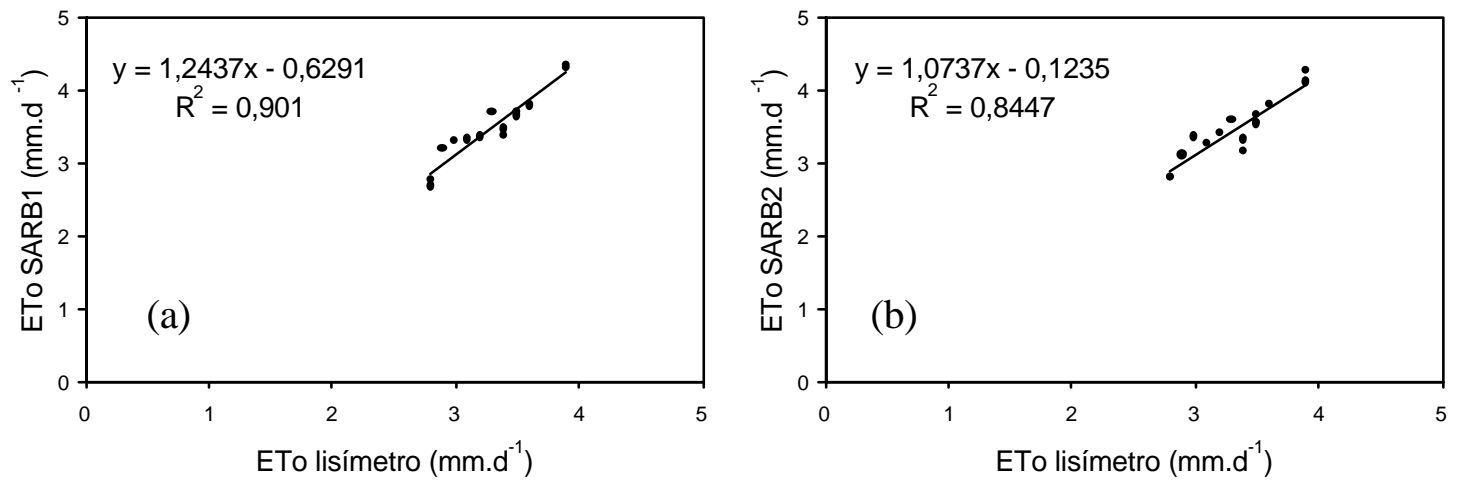

Figura 2 - Regressões entre os valores de ETo: (a) estimado por SARB 1 e medido por lisímetro; e (b) estimado por SARB 2 e medido por lisímetro, nos dias 11 a 25 de junho de 2000, em Piracicaba, SP.

Na Tabela 1 são apresentados os valores diários e médios de evapotranspiração de referência, estimados por dois sistemas automáticos de razão de Bowen, pelo modelo de Penman-Monteith e medidos pelo lisímetro de pesagem, durante os dias 11 a 25 de junho de 2000, em Piracicaba, SP. A evapotranspiração média de referência estimada pelo SARB 1 foi de 3,50 mm.d $\mathrm{d}^{-1}$, ou 52,50 mm para o período de observação; a evapotranspiração média de referência estimada pelo SARB 2 foi de $3,44 \mathrm{~mm} \cdot \mathrm{d}^{-1}$, ou $51,62 \mathrm{~mm}$ para o período de observação; a evapotranspiração média de referência estimada pelo modelo de PenmanMonteith foi de 3,36 mm.d $\mathrm{d}^{-1}$, ou 50,40 mm para o período de observação e os valores de ETo mensurados pelo lisímetro de pesagem foram de 3,32 mm.d ${ }^{-1}$ ou 49,80 mm, para todo o período analisado. 
Tabela 1. Valores diários e médios de evapotranspiração de referência, em mm. $\mathrm{d}^{-1}$, estimados por dois sistemas automáticos de razão de Bowen, pelo modelo de PenmanMonteith e medidos pelo lisímetro de pesagem, durante os dias 11 a 25 de junho de 2000, em Piracicaba, SP.

\begin{tabular}{|c|c|c|c|c|}
\hline \multirow[b]{2}{*}{ Dias } & \multicolumn{4}{|c|}{ Evapotranspiração de Referência $\left(\mathrm{mm}^{\left.-\mathrm{d}^{-1}\right)}\right.$} \\
\hline & SARB 1 & SARB 2 & Penman-Monteith & Lisímetro \\
\hline $11 / 06 / 00$ & 3,32 & 3,26 & 3,12 & 3,10 \\
\hline $12 / 06 / 00$ & 3,36 & 3,15 & 3,39 & 3,40 \\
\hline $13 / 06 / 00$ & 3,45 & 3,31 & 3,43 & 3,40 \\
\hline $14 / 06 / 00$ & 3,64 & 3,53 & 3,60 & 3,50 \\
\hline $15 / 06 / 00$ & 3,69 & 3,55 & 3,45 & 3,50 \\
\hline $16 / 06 / 00$ & 3,69 & 3,57 & 3,23 & 3,30 \\
\hline $17 / 06 / 00$ & 2,67 & 2,80 & 2,9 & 2,80 \\
\hline $18 / 06 / 00$ & 3,20 & 3,10 & 2,80 & 2,90 \\
\hline $19 / 06 / 00$ & 3,29 & 3,35 & 3,10 & 3,00 \\
\hline $20 / 06 / 00$ & 2,75 & 2,80 & 2,80 & 2,80 \\
\hline $21 / 06 / 00$ & 3,35 & 3,40 & 3,25 & 3,20 \\
\hline $22 / 06 / 00$ & 3,68 & 3,65 & 3,45 & 3,50 \\
\hline $23 / 06 / 00$ & 4,33 & 4,10 & 4,00 & 3,90 \\
\hline $24 / 06 / 00$ & 4,30 & 4,25 & 4,10 & 3,90 \\
\hline $25 / 06 / 00$ & 3,78 & 3,80 & 3,75 & 3,60 \\
\hline Média & 3,50 & 3,44 & 3,36 & 3,32 \\
\hline
\end{tabular}

A variação da ETo foi semelhante em todos os dias analisados, assim sendo foi selecionados o dia 17 de junho de 2000 como representativo de todo o período. A variação da evapotranspiração de referência durante o período de luz no dia 17 de junho de 2000, estimados pelos dois sistemas automáticos de razão de Bowen (SARB1 e SARB2), pelo modelo de Penman-Monteith e determinado por um lisímetro de pesagem, para uma 
integração de 120 minutos, é mostrado na Figura 3.. Esta foi similar nos dois equipamentos de razão de Bowen, apresentando um valor máximo próximo às 12 horas, porém o início da mensuração pelo modelo de Penman-Monteith e pelo lisímetro foi às 6 horas, enquanto que o início da estimativa pelos sistemas automáticos de razão de Bowen foi às 8 horas. Es te fato foi observado em todos os dias do período de coleta de dados e pode ser explicado pela ausência de gradiente de temperatura e de pressão de vapor.

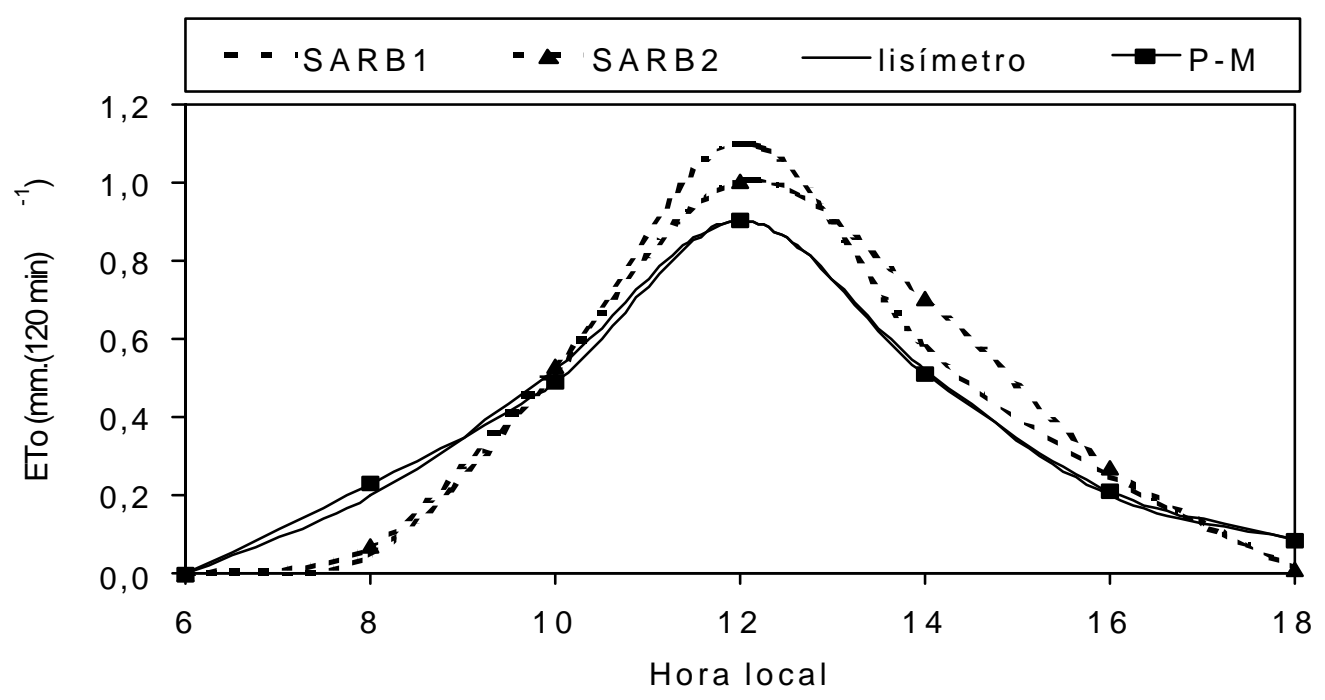

Figura 3 - Curvas de variação da evapotranspiração de referência, em mm.(120 min) ${ }^{-1}$, estimados por dois sistemas automáticos de razão de Bowen (SARB1 e SARB2), pelo modelo de Penman-Monteith (P-M) e medidos pelo lisímetro de pesagem, durante os dias 17 de junho de 2000, em Piracicaba, SP.

Deve-se observar que, durante todo o período analisado praticamente não houve a ocorrência de precipitação, somente chovendo cerca de $1,5 \mathrm{~mm}$ no dia 21 de junho. Com isso, o efeito da precipitação sobre o funcionamento dos sistemas automático de razão de Bowen não pode ser avaliado neste trabalho. 


\subsection{Conclusões}

As estimativas da evapotranspiração obtidas pelos sistemas automáticos de razão de Bowen superestimaram as determinações realizadas pelo lisímetro no período analisado.

A estimativa da evapotranspiração apresentou uma excelente correlação entre os dois equipamentos de razão de Bowen no período analisado.

Os sistemas automáticos de razão de Bowen apresentaram pequena necessidade de manutenção durante o período analisado. 


\section{VARIAÇÃO DA EVAPOTRANSPIRAÇÃO DO CAPIM TANZÂNIA (Panicum maximum Jacq.) OBTIDA POR SISTEMAS AUTOMÁTICOS DA RAZÃO DE BOWEN E LISÍMETRO DE PESAGEM}

\section{Resumo}

O desempenho dos sistemas automáticos de razão de Bowen já foram avaliados em diversos trabalhos, levando-se em conta períodos diários, porém ainda são escassos estudos do comportamento temporal da evapotranspiração obtida por estes aparelhos, para uma escala em minutos. Este trabalho teve como objetivo, analisar o comportamento temporal da evapotranspiração do capim tanzânia (Panicum maximum Jacq.), utilizando um sistema automático de razão de Bowen e um lisímetro de pesagem. $\mathrm{O}$ experimento foi conduzido em uma área de 63000 m², cultivados com capim tanzânia, irrigada por aspersão com pivô central, em Piracicaba, SP. A evapotranspiração da cultura (ETc) foi obtida por meio de um sistema automático da razão de Bowen e um lisímetro de pesagem. Os dados foram coletados nos dias 10 de maio a 08 de junho de 2000 e os valores médios obtidos, em intervalos de 20, 60 e 120 minutos, foram armazenados em um sistema de aquisição de dados. O lisímetro de pesagem foi cultivado com o capim tanzânia e os dados foram armazenados em um sistema de aquisição de dados em intervalos de 20, 60 e 120 minutos. Os valores de evapotranspiração médios diários e totais obtidos pelo sistema automático da razão de Bowen foram 3,39 mm.d

${ }^{1}$ e 101,68 mm e os valores obtidos pelo lisímetro de pesagem foram 3,26 mm. $\mathrm{d}^{-1}$ e 97,66 mm, para o período de 30 dias. O método do balanço de energia e o lisímetro de pesagem apresentaram uma mesma tendência em relação às variações das condições meteorológicas diárias durante o período de observação. A variação da evapotranspiração ao longo do dia foi semelhante para os dois equipamentos, com a evapotranspiração elevando-se das 6 às 12 horas para o lisímetro, e das 8 às 12 horas para o sistema automático de razão de Bowen. Entretanto diferenças entre os valores obtidos pelos dois métodos foram observadas para períodos de integração de 20 e 60 minutos, existindo uma grande variação principalmente na 
medida que provém do lisímetro, que se deve a ação dos ventos que chocam com a superfície vegetada do lisímetro. O sistema automático da razão de Bowen apresenta desempenho adequado tanto na escala diária como na horária, sendo que o período de integração de 120 minutos apresentou a melhor correlação entre o valores obtidos pelo lisímetro e pelo sistema automático de razão de Bowen.

\section{Summary}

Automated Bowen ratio systems performance have been evaluated in past researches mostly for a daily basis, however scarce studies can be found about the evapotranspiration temporal trends using these systems on a scale of minutes. This work has the objective to analyze the temporal trends of evapotranspiration of Guinea grass (Panicum maximum Jacq.), using an automated Bowen ratio system and a weighing lysimeter. The experiment was conducted in an area of $63,000 \mathrm{~m}^{2}$, cultivated with Guinea grass, irrigated with a center pivot system, in Piracicaba, SP, Brazil. Crop evapotranspiration (ETc) was obtained with an automated Bowen ratio system and with an weighing lysimeter. The data were collected between May 10 and June 8, 2000 and a data logger system was used to average the data over 20, 60 e 120 minutes intervals and to store the data. The weighing lysimeter was cultivated with Guinea grass and the data were similarly acquired over 20, 60 e 120 minutes intervals using a data logger system. Daily average evapotranspiration and total evapotranspiration over the nine days period were respectively $3.39 \mathrm{~mm}$ e $101.68 \mathrm{~mm}$ for the automated Bowen ratio system while for the weighing lysimeter were respectively $3.26 \mathrm{~mm}$ e $97.66 \mathrm{~mm}$. The energy balance method and the weighing lysimeter presented the same trends in relation to the daily meteorological conditions over the observation period. The evapotranspiration trends throughout the day were similar for both methods, showing an increase in evapotranspiration from 6:00 to 12:00 local time and 8:00 to 12:00 local time to the automated Bowen ratio system. However, differences between the two systems were observed for the averaging periods of 20 and 60 minutes, where large variations were 
observed mainly for the lysimeter, which were attributed to the wind blown over the lysimeter vegetated surface. The automated Bowen ratio system presented an adequate performance for the daily and for the hourly integration times, while the 120 minutes integration period presented the best correlation between the lysimeter and the automated Bowen ratio system.

\subsection{Introdução}

Nos últimos anos no Brasil, ocorreu um crescimento nas áreas de pastagens irrigadas, com consequiente aumento de massa verde e ganho de peso para gado de corte. Com esse crescimento, tem-se uma demanda de informações técnicas no consumo diário de água no capim.

A irrigação em pastagens vêm sendo executada sem nenhum critério técnico, pois há escassez nas informações referentes ao consumo hídrico de pastagens, gerando, com isso dois problemas de produção: o primeiro quando não é aplicada a lâmina adequada ao desenvolvimento potencial dos pastos, acarretando baixa produção de matéria verde; e o segundo, que é mais frequiente, quando se aplica uma lâmina excessiva, acarretando no aumento dos custos, má utilização dos recursos hídricos e lixiviação dos nutrientes.

Numa superfície vegetada ocorrem simultaneamente os processos de evaporação e de transpiração. Thorntwaite definiu, no início da década de 40, a evapotranspiração potencial (ETp) como a quantidade de água utilizada por uma extensa área vegetada, em crescimento ativo, sob condições ótimas de umidade do solo. A evapotranspiração real ou atual (ETr) é aquela que ocorre em uma superfície vegetada, independente de sua área e das condições de umidade do solo (Thornthwaite, 1948; Villa Nova \& Reichardt, 1989; Pereira, 1998). A evapotranspiração da cultura (ETc) é a quantidade de água utilizada por uma cultura agronômica, livre de doenças, desenvolvendo-se em uma área cultivada de um ou mais hectares, sob condições otimizadas de solo, incluindo água e fertilidade (Doorenbos \& Pruitt, 1977). 
O manejo da irrigação requer estimativas diárias da evapotranspiração da cultura com uma precisão comparável a uniformidade de aplicação de água pelo sistema de irrigação. Vários métodos de estimativa do consumo hídrico de culturas têm sido utilizados, sendo que os métodos meteorológicos, que calculam a quantidade de água evapotranspirada pelas culturas, utilizam basicamente elementos climáticos como parâmetros de entrada.

O método do balanço de energia utilizando a razão de Bowen tem sido empregado com muito sucesso em muitos estudos (Tanner, 1960; Villa Nova, 1973; Sinclar et al., 1975; Bergamaschi et al., 1988.). Esse método permite estimar as necessidades hídricas dos vegetais medindo a energia disponível e separando-a em diferentes processos, entre eles a evapotranspiração.

Segundo Rosenberg (1974) a energia líquida disponível na superfície da terra se reparte em fluxo de calor para o solo, fluxo de calor sensível para o ar, fluxo de calor latente de evaporação, fotossíntese e trocas devidas a atividade metabólicas e ao armazenamento nos tecidos das plantas. Ainda segundo o mesmo, pode-se desprezar os dois últimos componentes pois os seus valores são, em geral, inferiores ao erro experimental na medida dos componentes principais. Portanto, o balanço de energia considera, geralmente apenas os três primeiros processos.

O lisímetro, também conhecido como evapotranspirômetro, é um equipamento que mensura a evapotranspiração real da cultura que nele é cultivada, por meio de um balanço hídrico. É tido por muitos autores como o valor real, ou seja, fornece a medida da evapotranspiração. Porém esse fato é questionado por outros autores, que consideram os valores obtidos, como uma estimativa da evapotranspiração.

Este trabalho tem como objetivo, analisar o comportamento temporal da evapotranspiração do capim tanzânia (Panicum maximum Jacq.), utilizando um sistema automático de razão de Bowen e um lisímetro de pesagem.

\subsection{Material e Métodos}


O trabalho foi conduzido na área experimental de irrigação do Departamento de Engenharia Rural da Escola Superior de Agricultura "Luiz de Queiroz", ESALQ/USP, situada na fazenda Areão, no município de Piracicaba, SP. O local apresenta como coordenadas geográficas $22^{\circ} 42^{\prime} 30^{\prime \prime}$ de latitude Sul, $47^{\circ} 30^{\prime} 00^{\prime \prime}$ de longitude Oeste; e aproximadamente 576 metros de altitude. O solo possui uma declividade aproximada de $2 \%$ e é classificado como argissolo vermelho (EMBRAPA, 1999), com horizonte A de textura argilosa (média de $45 \%$ de argila) e profundidade média de $0,30 \mathrm{~m}$.

O clima de Piracicaba é Cwa, ou seja, subtropical úmido conforme a classificação de Köepen, com verão chuvoso e inverno seco, sendo de $1250 \mathrm{~mm}$ a precipitação média anual. As temperaturas médias mensais variam de $24,8{ }^{\circ} \mathrm{C}$ no verão a $17,1{ }^{\circ} \mathrm{C}$ no inverno, com média anual de $21,4^{\circ} \mathrm{C}$.

O presente trabalho foi realizado m período de 10 maio a 8 de junho de 2000 , totalizando 30 dias de coleta de dados.

A área experimental foi cultivada com capim tanzânia (Panicum maximum Jacq.) e irrigada por pivô-central apresentando uma área total de $63.000 \mathrm{~m}^{2}$. O capim foi pastejado pelo gado da raça Nelore um dia antes do início do período analisado, acarretando em um resíduo cultural de aproximadamente $0,40 \mathrm{~m}$ de altura.

O sistema automático de razão de Bowen (Campbell Scientific, Bowen ratio system) instalado na área experimental cultivada com o capim tanzânia, foi conectado a um sistema de coleta e aquisição de dados (Campbell Scientific, Datalogger modelo 21X) programado para realizar leituras a cada dez segundos e armazenar valores médios em intervalos de 20 minutos. Os dados obtidos com o equipamento, são: radiação líquida (Rn); fluxo de calor no solo, realizado em dois pontos $\left(\mathrm{G}_{1}\right.$ e $\left.\mathrm{G}_{2}\right)$; gradientes de temperatura e de tensão de vapor d'água do ar acima da superfície. A temperatura do ar $\left({ }^{\circ} \mathrm{C}\right)$ e a umidade absoluta $\left(\mathrm{kg} \cdot \mathrm{m}^{-3}\right)$ foram mensuradas nos níveis 0,10 e 1,00 m acima da superfície vegetada. A radiação líquida (MJ.m${ }^{2} \cdot \mathrm{d}^{-1}$ ) foi mensurada a $1,00 \mathrm{~m}$ acima da superfície vegetada e os fluxos de calor no solo (MJ.m 
${ }^{2} \cdot \mathrm{d}^{-1}$ ) foram mensurados a $0,08 \mathrm{~m}$ abaixo de superfície vegetada. A partir das medições de radiação líquida $(R n)$, fluxos de calor no solo $\left(G_{1}\right.$ e $\left.G_{2}\right)$, diferenças de temperatura $(\Delta T)$ e pressão de vapor $(\Delta \mathrm{e})$ entre dois níveis, o balanço de energia pode ser apresentado conforme a seguinte equação.

$$
\mathrm{Rn}-\mathrm{G}-\mathrm{H}-\mathrm{LE}=0
$$

De posse dos valores de gradientes de temperatura $(\Delta \mathrm{T})$, de gradientes de tensão do vapor d'água do ar $(\Delta \mathrm{e})$ e coeficiente psicrométrico $(\gamma)$ para o equipamento com ventilação forçada, efetuou-se os cálculos, de forma a estimar o valor da razão de Bowen ( $\beta$ ), para cada intervalo de tempo correspondente a 20 minutos, conforme a equação (2):

$$
\beta=\gamma \frac{\Delta \mathrm{T}}{\Delta \mathrm{e}}
$$

em que:

$\gamma=$ coeficiente psicrométrico, igual a $0,0626 \mathrm{kPa}^{.} \mathrm{C}^{-1}$.

$\mathrm{O}$ valor do coeficiente psicrométrico foi obtido por meio da seguinte equação:

$$
\gamma=\frac{P . c p}{\lambda \cdot \varepsilon}
$$

em que:

$\mathrm{P}=$ pressão atmosférica, igual a $94,93 \mathrm{kPa}$;

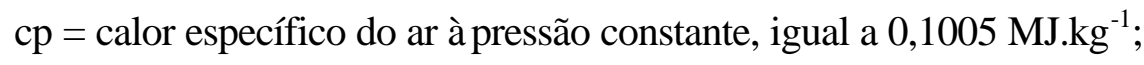

$\lambda=$ calor latente de evaporação, igual a 2,45 MJ.kg ${ }^{-1} ; \mathrm{e}$

$\varepsilon=$ razão entre a massa molecular do vapor d'água e a massa molecular do ar, igual a 0,622 .

O fluxo de calor latente, em MJ.m $\mathrm{m}^{-2} \cdot \mathrm{d}^{-1}$, era então estimado por meio da seguinte equação.

$$
L E=\frac{R n-\left(\frac{G_{1}+G_{2}}{2}\right)}{(1+\beta)}
$$


Considerou-se como positivo o fluxo que fluía da atmosfera ou subsolo para a superfície, e negativo quando fluía da superfície para a atmosfera ou subsolo. Entretanto, matematicamente para que tais considerações fossem aplicadas corretamente, no cálculo do fluxo de calor latente, fez-se necessário adicionar o sinal de "negativo" junto ao saldo de radiação. Devido a convenção adotada, pelo SARB, fez-se também necessário adicionar o sinal "negativo" aos valores obtidos com os fluxos de calor no solo. Assim sendo, a equação (4) pode ser escrita da seguinte maneira.

$$
L E=\frac{-R n-\left(\frac{-G_{1}-G_{2}}{2}\right)}{(1+\beta)}
$$

Bowen (1926) relacionou os fluxos de calor sensível (H) e latente (LE), conforme equação abaixo, sendo a mesma conhecida como razão de Bowen $(\beta)$ e tendo sida amplamente utilizada na estimativa da evapotranspiração (Mastorilli et al., 1989; Fontana et al., 1991; Herbst et al., 1996; Steduto \& Hsiao, 1998).

$$
\beta=\frac{H}{L E}
$$

Após a estimativa da razão de Bowen para cada intervalo de tempo, e de posse dos valores da radiação líquida $(\mathrm{Rn})$ e dos fluxos de calor sensível no solo $\left(\mathrm{G}_{1}\right.$ e $\left.\mathrm{G}_{2}\right)$, obtidos com sensores automáticos, foi possível realizar a estimativa do fluxo de calor sensível, $\mathrm{H}$, em MJ.m ${ }^{2} \cdot d^{-1},($ equação 7$)$.

$$
\mathrm{H}=\beta . \mathrm{LE}
$$

Conhecidos todos os valores significativos dos componentes do balanço de energia foi possível calcular a estimativa da evapotranspiração do capim tanzânia (ETc), em mm.20min ${ }^{-1}$, para cada intervalo de tempo de 20 minutos, em todo o período estudado.

$$
\mathrm{ETc}=\frac{\mathrm{LE}}{2,45 \cdot 72 \cdot \mathrm{t}}
$$

em que: 
$\mathrm{t}=$ intervalo de tempo considerado, ou seja, 20 minutos ;

$72=$ constante utilizada para ajustar a escala de tempo; e

2,45 = constante utilizada para converter o fluxo de calor latente em água evapotranspirada.

Na estimativa de evapotranspiração do capim tanzânia (ETc) foram considerados valores diários conforme recomendação de Heilman \& Brittin (1989), Cellier \& Olioso (1993) e Kustas et al. (1996). Foram descartadas as estimativas de ETc originários de valores da razão de Bowen entre - 0,7 e - 1,3, conforme Uhland et al. (1996).

Enfatiza-se que, considerou-se como período diurno aquele compreendido entre 6 e 18 horas. A soma dos totais de evapotranspiração, a cada 20 minutos, ocorridos no período citado, excetuado as condições preconizadas no parágrafo anterior, correspondeu a estimativa da evapotranspiração diária. Ressalta-se, ainda, que semanalmente foram feitas manutenções no sistema razão de Bowen, em conformidade com o recomendado pelo fabricante, através de calibrações no higrômetro, limpeza dos termopares de cromo-constantan, das mangueiras de suçãa, do painel solar e da estrutura de sustentação e troca, quinzenal, dos filtros de papel colocados nos orifícios de sucção.

A medida direta da evapotranspiração da cultura (ETc) foi obtida por meio de um lisímetro de pesagem, o qual era composto por três células de carga com capacidade de 1000 $\mathrm{kg}$ cada. $\mathrm{O}$ lisímetro possui as seguintes dimensões: $0,70 \mathrm{~m}$ de profundidade, $1,50 \mathrm{~m}$ de comprimento e 1,30 m de largura. $\mathrm{O}$ cultivo e o manejo do capim, ocorreu de forma semelhante a toda área experimental, essa metodologia foi adotada para que tivéssemos uma representatividade suficiente do capim cultivado dentro do lisímetro em relação ao restante da área experimental.

No dia 9 de maio de 2000 foi realizado um corte no capim, de forma que, o mesmo ficasse com uma altura de $0,40 \mathrm{~m}$ em relação ao solo. Nesse mesmo dia foi realizada uma 
irrigação, que elevou a umidade do solo à capacidade de campo. Logo após a irrigação realizou-se a calibração do SARB.

\subsection{Resultados e Discussão}

A Figura 1 mostra a variação dos fluxos de energia obtidos por meio do sistema automático de razão de Bowen, para o dia 15 de maio de 2000. Nota-se que, a radiação líquida $(\mathrm{Rn})$, apresenta um comportamento semelhante, porém inverso ao do calor latente de evaporação (LE), o que demonstra ser Rn o componente que mais contribui no balanço de energia com a evapotranspiração, neste caso. Há também uma variação do calor sensível $(\mathrm{H})$ das 12 às 14 horas. O fluxo de calor no solo (G) apresenta uma pequena variação ao longo do dia. Pode-se notar que, no início da manhã e no fim da tarde o fluxo de calor latente estimado foi praticamente nulo, acompanhando a radiação líquida. A estimativa do fluxo de calor sensível do ar iniciou-se por volta das 10 horas, devido ao aquecimento da superfície do solo.

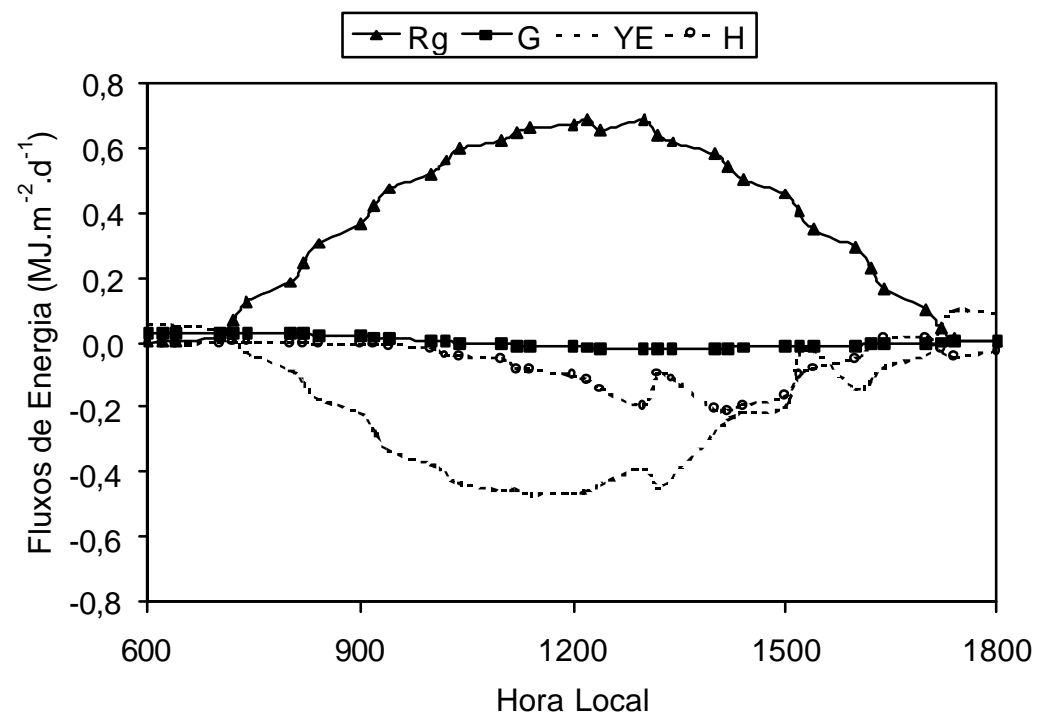

Figura 1 - Fluxos de energia para o dia 15 de maio de 2000, obtidos pelo sistema automático de razão de Bowen locado sobre o capim tanzânia, em Piracicaba, SP. 
Verifica-se ainda na Figura 1 que, por volta de 17 horas ocorreu uma inversão no sentido do fluxo de calor latente concomitantemente com a inversão do valor de $\mathrm{Rn}$.

A variação da evapotranspiração ao longo do dia 15 de maio de 2000, para um período de integração de 120 minutos, está representada na Figura 2. Verifica-se que a variação da evapotranspiração ao longo do dia, obtido pelo SARB e pelo lisímetro foi semelhante, porém a medida do lisímetro foi menor, mas com início às 6:00 h, enquanto que o obtido pelo SARB foi maior, mas com início a partir somente às 8:00 h. Esse comportamento se repetiu para todos os dias analisados, e pode ser explicado pela ausência de gradiente de temperatura e pressão de vapor nas duas alturas analisadas nas primeiras horas do dia.

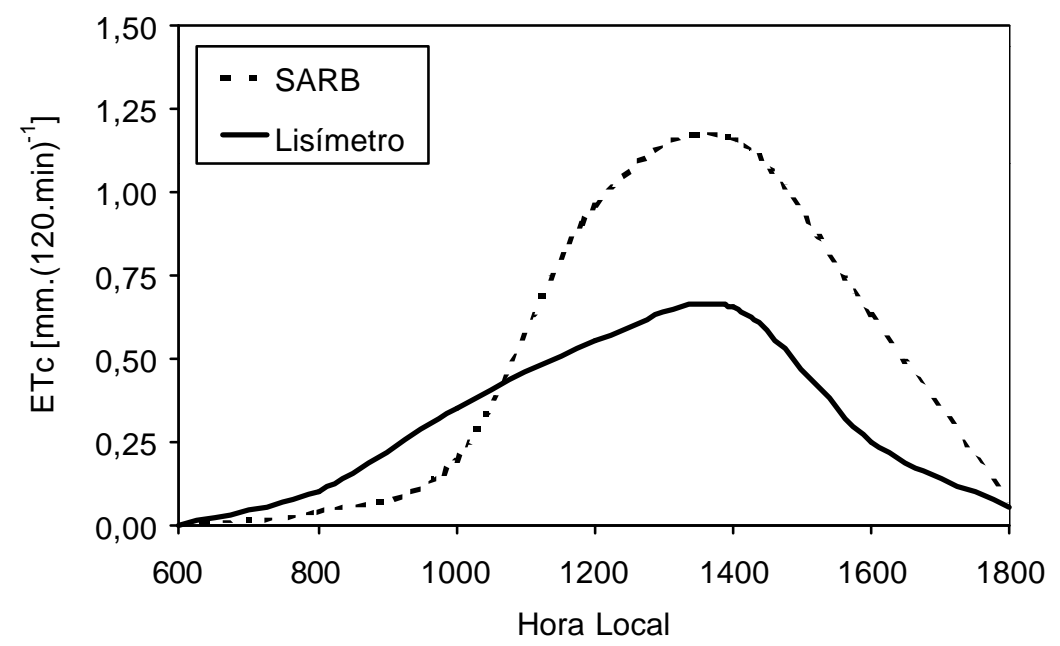

Figura 2 - Evapotranspiração do capim tanzânia obtida pelo SARB e o lisímetro de pesagem durante o dia 15 de maio para um período de integração de 120 minutos, em Piracicaba, SP.

Nas Figuras 3 e 4, tem-se as variações da evapotranspiração medidas ao longo do dia 15 de maio de 2000, para os períodos de integração de 60 e 20 minutos, respectivamente. 
Pode-se notar que existe uma grande variação principalmente na medida que provém do lisímetro, esse efeito se deve a ação dos ventos que chocam com a superfície vegetada do lisímetro.

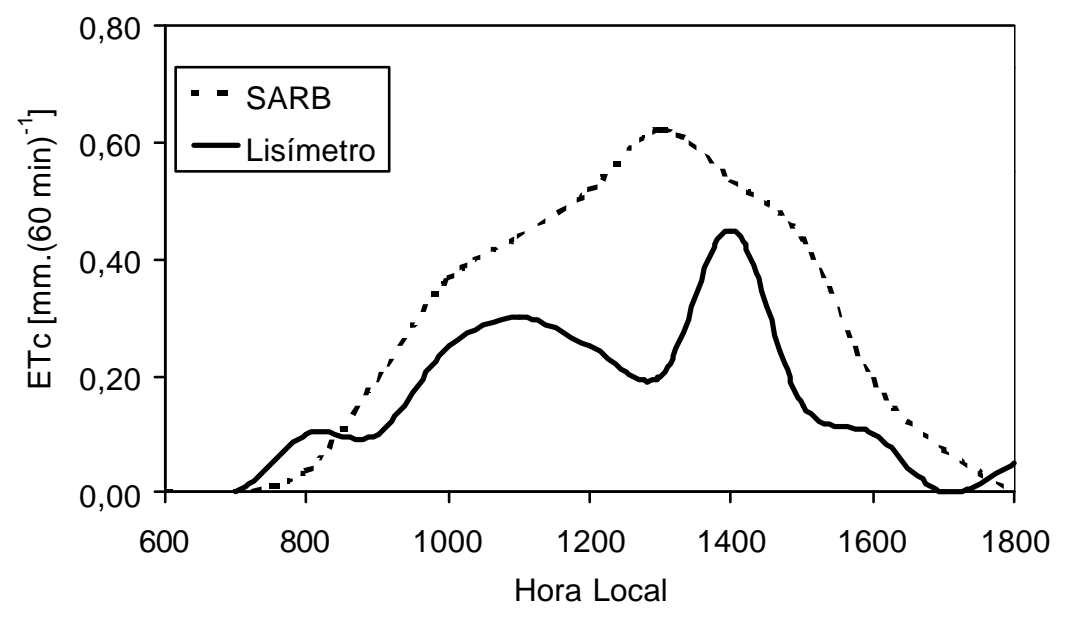

Figura 3 - Evapotranspiração do capim tanzânia obtida pelo SARB e o lisímetro durante o dia 15 de maio para um período de integração de 60 minutos.

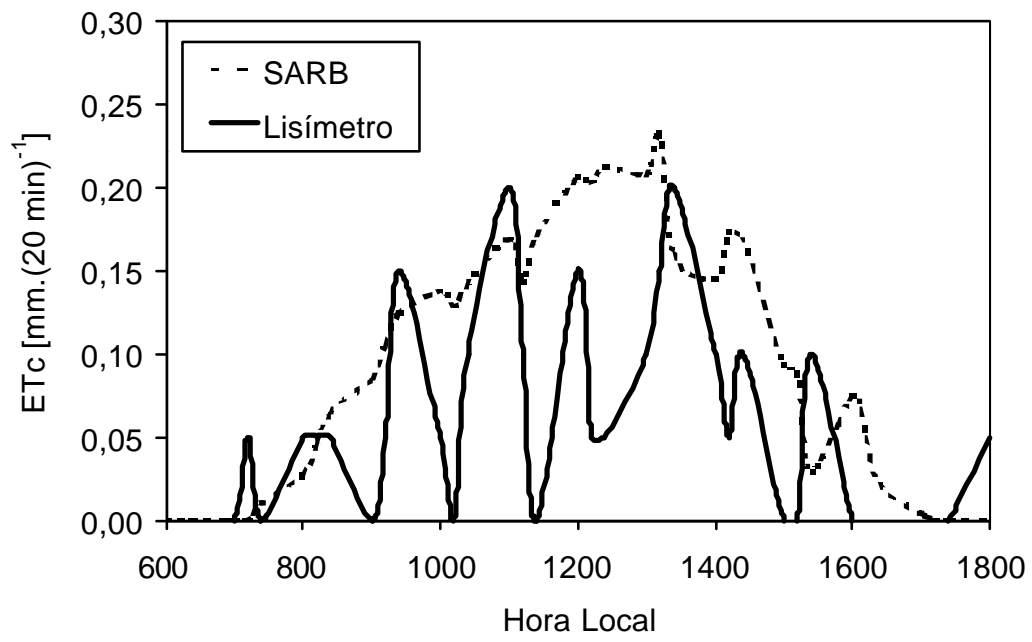


Figura 4 - Evapotranspiração do capim tanzânia obtida pelo SARB e o lisímetro durante o dia 15 de maio para um período de integração de 20 minutos.

Na Figura 4, nota-se que a sensibilidade do lisímetro de pesagem é maior que 0,05 $\mathrm{mm} .20 \mathrm{~min}^{-1}$.

É importante lembrar que o clima, a planta e o solo são importantes fatores que controlam a evapotranspiração das culturas, a demanda atmosférica, principalmente quando sob ótimas condições de umidade no solo. No caso particular deste experimento, não ocorreu restrições de umidade no sistema solo-planta em relação ao uso de água para o desenvolvimento da cultura. Porém o efeito da chuva no desempenho dos equipamentos neste experimento não pode ser evidenciado, pois somente no dia 31 de maio de 2000 ocorreu uma precipitação de $3,5 \mathrm{~mm}$.

Na Figura 5 observa-se que o método do balanço de energia e o lisímetro de pesagem apresentaram uma mesma tendência em relação às variações das condições meteorológicas diárias durante o período de observação. A dispersão dos valores de evapotranspiração obtidos pelos dois métodos apresentaram uma boa correlação (coeficiente de determinação igual a 0,8664 ) podendo ser evidenciada na Figura 6.

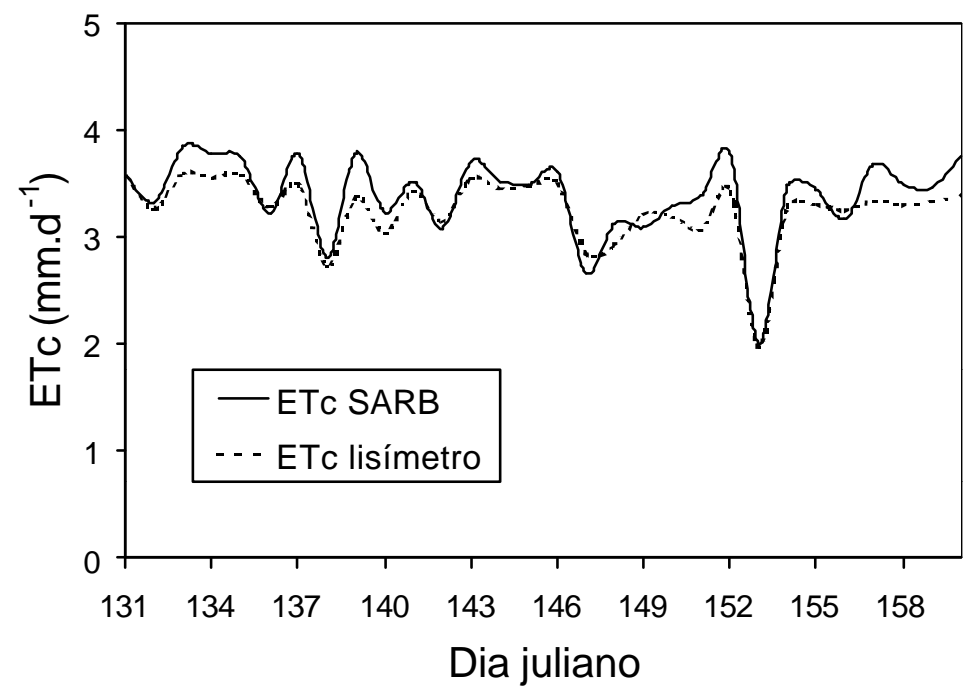


Figura 5 - Variação de evapotranspiação do capim tanzânia, estimado pelo sistema automático de razão de Bowen (ETc SARB) e medidos pelo lisímetro (ETc lisímetro), para o período de 10 maio a 8 de junho de 2000, em Piracicaba, SP.

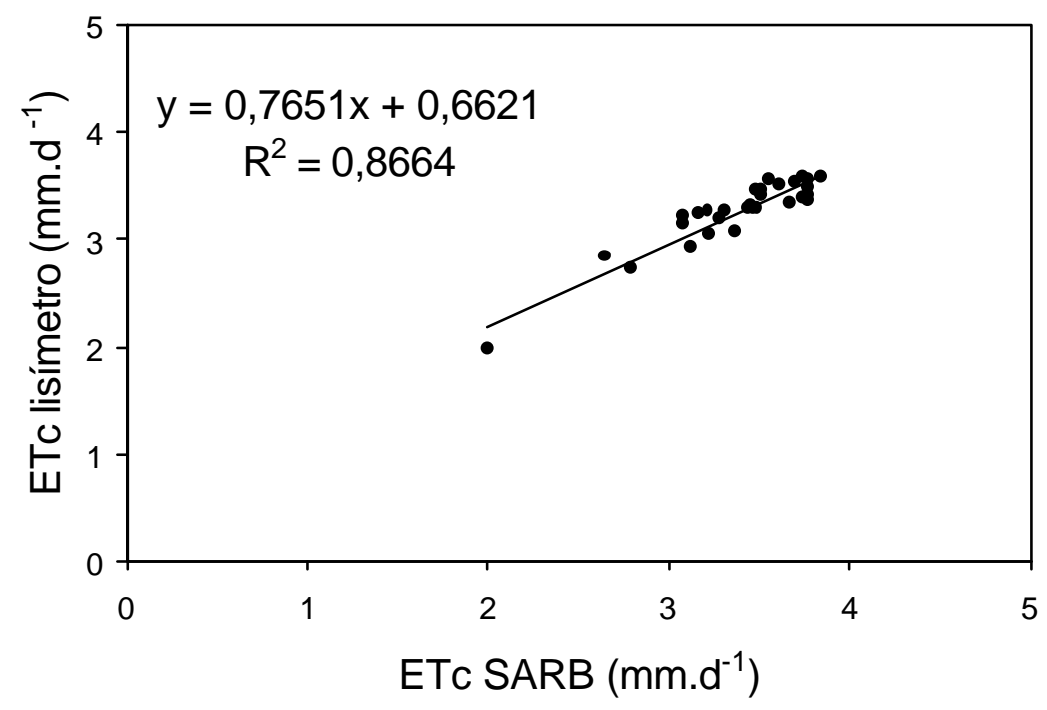

Figura 6 - Regressão linear de evapotranspiação do capim tanzânia, estimado pelo sistema automático de razão de Bowen (ETc SARB) e medidos pelo lisímetro (ETc lisímetro), para o período de 10 maio a 8 de junho de 2000, em Piracicaba, SP.

Os valores de evapotranspiração médios diários e totais obtidos pelo sistema automático da razão de Bowen foram 3,39 mm. $\mathrm{d}^{-1}$ e 101,68 mm e os valores obtidos pelo lisímetro de pesagem foram 3,26 mm.d e 97,66 mm, para o período de 30 dias.

Os valores de evapotranspiração obtidos pelo sistema automático da razão de Bowen superestimaram os valores obtidos pelo lisímetro de pesagem. Esta superestimativa é devido à contribuição advectiva pois a circunvizinha à area cultivada com capim tanzânia forneceu uma contribuição de calor sensível, por meio da ação dos ventos, que durante o período deste experimento foram de médios a fortes.

\subsection{Conclusões}


O sistema automático da razão de Bowen apresenta desempenho adequado tanto na escala diária como na horária, sendo que o período de integração de 120 minutos apresentou a melhor correlação entre o valores obtidos pelo lisímetro e pelo sistema automático de razão de Bowen. O SARB é um equipamento eficiente para a determinação da evapotranspiração, porém está susceptível ao efeito advectivo.

O presente lisímetro é um equipamento eficiente para a determinação da evapotranspiração. Entretanto para períodos de integração de 20 e 60 minutos existe uma grande variação principalmente na medida do lisímetro, que se deve a ação dos ventos que chocam com a superfície vegetada do equipamento.

A utilização de métodos de estimativa da evapotranspiração que utilizam variáveis ambientais com aquisição automática de dados em tempo real, como o método do balanço de energia apresentou um desempenho satisfatório em relação ao lisímetro, conforme dados obtidos neste trabalho. 


\section{DETERMINAÇÃO DA EVAPOTRANSPIRAÇÃO DO CAPIM TANZÂNIA (Panicum maximum Jacq.), UTILIZANDO UM SISTEMA AUTOMÁTICO DE RAZÃO DE BOWEN E UM LISÍMETRO DE PESAGEM}

\section{Resumo}

A irrigação de pastagens no Brasil, apresentou um crescimento acentuado nos últimos anos. No entanto, em função da ausência de pesquisas sobre a aplicação de água as pastagens, o manejo da irrigação não vem sendo realizado de maneira racional. Os objetivos deste trabalho foram: determinar a evapotranspiração do capim tanzânia (Panicum maximum Jacq.), por meio das medidas de lisímetro de pesagem; aplicar o método do balanço de energia para a estimativa da evapotranspiração do capim, por meio de um sistema automático de razão de Bowen; e comparar os valores de evapotranspiração do capim tanzânia, medidos em lisímetro de pesagem com os estimados pelo balanço de energia por meio de um sistema automático de razão de Bowen. O experimento foi conduzido em Piracicaba, SP entre os dias 21 de julho de 2000 e 15 de julho de 2001. Por meio de um lisímetro de pesagem e um sistema automático de razão de Bowen foram obtidos valores de evapotranspiração do capim tanzânia (ETc). Os dados foram coletados diariamente e analisados, estatisticamente, mediante análise de regressão. A evapotranspiração média do capim tanzânia foi de $4,13 \mathrm{~mm} \cdot \mathrm{d}^{-1}$, segundo o balanço de energia e $4,34 \mathrm{~mm} \cdot \mathrm{d}^{-1}$, obtido pelo lisímetro de pesagem. Com base nos resultados, concluiu-se que a estimativa da evapotranspiração, obtida pelo sistema automático de razão de Bowen, pode ser influenciada pela contribuição advectiva, provinda de áreas não irrigadas circunvizinhas àárea irrigada, principalmente em regiões de clima seco e com ventos fortes, e também pela ocorrência de chuvas de longa duração, devido a ausência de gradientes de temperatura do ar e umidade absoluta. Apesar disso houve uma razoável correlação com as medidas feitas em lisímetro de pesagem.

\section{Summary}


Pasture irrigation in Brazil presented a large increase in recent years, however irrigation management practices have been done irrationally due to a lack of research on water use by pastures. The objectives of this research were to determine evapotranspiration of Guinea grass (Panicum maximum Jacq.) by measurements of a weighing lysimeter; to apply the energy balance method to estimate evapotranspiration of Guinea grass by means of an automated Bowen ratio system; and to compare the values of evapotranspiration of Guinea grass measured with a weighing lysimeter with that estimated by the energy balance method determined with an automated Bowen ratio system. The experiment was conducted in Piracicaba, SP, Brazil, between July 21, 2000 and July 15, 2001. Evapotranspiration values of Guinea grass (ETc) were obtained by means of a weighing lysimeter and an automated Bowen ratio system. The data were collected on a daily basis and statistically analyzed through regression analysis. The average evapotranspiration of Guinea grass was $4.13 \mathrm{~mm}^{\text {day }}{ }^{-1}$ by the energy balance method and 4.34 mm.day ${ }^{-1}$ by the weighing lysimeter. Through these results, it was concluded that the automated Bowen ratio system evapotranspiration estimates can be influenced by advection coming from dry neighboring areas without irrigation, mainly in windy and dry climates, and also by long duration rainfalls, due to the lack of air temperature gradients and absolute air humidity. Despite of that, there was a reasonable correlation with the measurements of a weighing lysimeter.

\subsection{Introdução}

A irrigação de pastagens no Brasil apresentou um crescimento acentuado na década de 90, existindo atualmente centenas de equipamentos do tipo pivô-central irrigando pasto no país. Esta prática iniciou-se em função do declínio econômico de algumas culturas. Com isso, 
os produtores rurais passaram a utilizar o pivô-central, que anteriormente irrigava culturas tradicionais como soja, feijão, etc; a fim de suprir a necessidade hídrica das pastagens e obter principalmente um incremento de peso do gado de corte. Com esta nova prática, os pecuaristas principalmente do Centro-Oeste, Sudeste e Nordeste brasileiro, obtiveram inicialmente ótimos resultados. Porém com o passar dos anos, os bons resultados não foram mantidos. Este fato ocorreu principalmente, por causa do manejo da irrigação, que era realizado de maneira ineficiente, principalmente por falta de recomendações técnicas sobre irrigação em pastagens. A aplicação de água às pastagens, tem sido feita de maneira equivocada e a determinação do consumo hídrico é de fundamental importância, ou seja, para um correto manejo da irrigação, é necessária a estimativa da evapotranspiração.

A evapotranspiração é função dos elementos meteorológicos, do solo e da planta (Lemon et al, 1957). Penman (1956) argumenta que quando a cobertura do solo é completa, a evapotranspiração de referência é condicionada principalmente pelos elementos meteorológicos. A radiação líquida é o principal elemento meteorológico. A evapotranspiração é função dos elementos meteorológicos, do solo e da planta (Lemon et al, 1957). Villa Nova (1987) ressalta que é difícil separar a ação de cada um destes elementos, pois os mesmos agem simultaneamente. Assim, de uma maneira geral, para uma dada região, quanto maior for à disponibilidade de energia solar, temperatura do ar e velocidade do vento, e quanto menor for a umidade relativa do ar, maior deverá ser a taxa de evapotranspiração. Em regiões onde ocorrem advecções fortes, condição que comumente incide quando uma área úmida é circundada por uma área seca, a importância relativa da radiação líquida decresce e, em adição à radiação líquida, a advecção ou transferência de calor sensível das áreas secas circunvizinhas, poderá contribuir no processo evapotranspirativo com energia até maior que aquela disponível àárea úmida, aumentando desta forma a importância da velocidade do vento e umidade relativa do ar na evapotranspiração.

Estudos realizados por Tanner et al. (1987), Nie et al. (1992), Malek (1993), Azevedo (1999) e Silva (2000) mostram que, a evapotranspiração estimada pelo sistema 
automático de razão de Bowen apresenta uma boa correlação, quando comparada com os valores medidos pelo lisímetro.

Os objetivos deste trabalho foram: determinar a evapotranspiração do capim tânzania (Panicum maximum Jacq.), por meio das medidas de lisímetro de pesagem; aplicar o método do balanço de energia para a estimativa da evapotranspiração do capim, por meio de um sistema automático de razão de Bowen; e comparar os valores de evapotranspiração do capim tanzânia, medidos em lisímetro de pesagem com os estimados pelo balanço de energia por meio de um sistema automático de razão de Bowen.

\subsection{Material e Métodos}

O trabalho foi conduzido na área experimental de irrigação do Departamento de Engenharia Rural da Escola Superior de Agricultura "Luiz de Queiroz”, ESALQ/USP, situada na fazenda Areão, no município de Piracicaba, SP. O local apresenta como coordenadas geográficas $22^{\circ} 42^{\prime} 30^{\prime \prime}$ de latitude Sul, $47^{\circ} 30^{\prime} 00^{\prime \prime}$ de longitude Oeste; e aproximadamente 576 metros de altitude. O solo possui uma declividade aproximada de $2 \%$ e é classificado como argissolo vermelho (EMBRAPA, 1999), com horizonte A de textura argilosa (média de $45 \%$ de argila) e profundidade média de $0,30 \mathrm{~m}$.

O clima de Piracicaba é Cwa, ou seja, subtropical úmido conforme a classificação de Köepen, com verão chuvoso e inverno seco, sendo de $1250 \mathrm{~mm}$ a precipitação média anual. As temperaturas médias mensais variam de $24,8{ }^{\circ} \mathrm{C}$ no verão a $17,1{ }^{\circ} \mathrm{C}$ no inverno, com média anual de $21,4^{\circ} \mathrm{C}$.

O presente trabalho foi realizado no período de 21 de julho de 2000 a 15 de julho de 2001. Este período foi dividido em 10 ciclos de trinta e seis dias.

A área experimental foi cultivada com capim tanzânia (Panicum maximum Jacq.) e irrigada por pivô-central apresentando uma área total de $63.000 \mathrm{~m}^{2}$. O capim era pastejado 
pelo gado da raça Nelore a cada trinta e seis dia, acarretando em um resíduo de aproximadamente $0,40 \mathrm{~m}$ de altura.

O sistema automático de razão de Bowen (Campbell Scientific, Bowen ratio system) instalado na área experimental cultivada com o capim tanzânia, foi conectado a um sistema de coleta e aquisição de dados (Campbell Scientific, Datalogger modelo 21X) programado para realizar leituras a cada dez segundos e armazenar valores médios em intervalos de 20 minutos. Os dados obtidos com o equipamento, são: radiação líquida (Rn); fluxo de calor no solo, realizado em dois pontos $\left(\mathrm{G}_{1}\right.$ e $\left.\mathrm{G}_{2}\right)$; gradientes de temperatura e de tensão de vapor d'água do ar acima da superfície. A temperatura do ar $\left({ }^{\circ} \mathrm{C}\right)$ e a umidade absoluta $\left(\mathrm{kg}^{\mathrm{m}} \mathrm{m}^{-3}\right)$ foram mensuradas nos níveis 0,10 e 1,00 m acima da superfície vegetada. A radiação líquida (MJ.m${ }^{2} \cdot \mathrm{d}^{-1}$ ) foi mensurada a $1,00 \mathrm{~m}$ acima da superfície vegetada e os fluxos de calor no solo (MJ.m ${ }^{2} \cdot \mathrm{d}^{-1}$ ) foram mensurados a $0,08 \mathrm{~m}$ abaixo de superfície vegetada. A partir das medições de radiação líquida $(R n)$, fluxos de calor no solo $\left(G_{1}\right.$ e $\left.G_{2}\right)$, diferenças de temperatura $(\Delta T)$ e pressão de vapor $(\Delta \mathrm{e})$ entre dois níveis o balanço de energia pode ser apresentado conforme a seguinte equação.

$$
\mathrm{Rn}-\mathrm{G}-\mathrm{H}-\mathrm{LE}=0
$$

De posse dos valores de gradientes de temperatura $(\Delta \mathrm{T})$, de gradientes de tensão do vapor d'água do ar $(\Delta \mathrm{e})$ e coeficiente psicrométrico $(\gamma)$ para o equipamento com ventilação forçada, efetuou-se os cálculos, de forma a estimar o valor da razão de Bowen $(\beta)$, para cada intervalo de tempo correspondente a 20 minutos, conforme a equação (2):

$$
\beta=\gamma \frac{\Delta \mathrm{T}}{\Delta \mathrm{e}}
$$

em que:

$\gamma=$ coeficiente psicrométrico, igual a $0,0626 \mathrm{kPa} \cdot{ }^{\circ} \mathrm{C}^{-1}$.

O valor do coeficiente psicrométrico foi obtido por meio da seguinte equação:

$$
\gamma=\frac{P \cdot c p}{\lambda \cdot \varepsilon}
$$

em que: 
$\mathrm{P}=$ pressão atmosférica, igual a 94,93 $\mathrm{kPa}$;

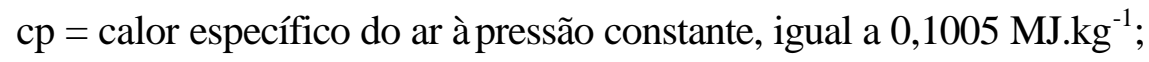

$\lambda=$ calor latente de evaporação, igual a 2,45 MJ.kg ${ }^{-1} ; \mathrm{e}$

$\varepsilon=$ razão entre a massa molecular do vapor d'água e a massa molecular do ar, igual a 0,622 .

O fluxo de calor latente, em MJ.m ${ }^{-2} \cdot \mathrm{d}^{-1}$, era então estimado por meio da seguinte equação.

$$
\mathrm{LE}=\frac{\mathrm{Rn}-\left(\frac{\mathrm{G}_{1}+\mathrm{G}_{2}}{2}\right)}{(1+\beta)}
$$

Considerou-se como positivo o fluxo que fluía da atmosfera ou subsolo para a superfície, e negativo quando fluía da superfície para a atmosfera ou subsolo. Entretanto, matematicamente para que tais considerações fossem aplicadas corretamente, no cálculo do fluxo de calor latente, fez-se necessário adicionar o sinal de "negativo" junto ao saldo de radiação. Devido a convenção adotada, pelo SARB, fez-se também necessário adicionar o sinal "negativo" aos valores obtidos com os fluxos de calor no solo. Assim sendo, a equação (4) pode ser escrita da seguinte maneira.

$$
L E=\frac{-R n-\left(\frac{-G_{1}-G_{2}}{2}\right)}{(1+\beta)}
$$

Bowen (1926) relacionou os fluxos de calor sensível (H) e latente (LE), conforme equação abaixo, sendo a mesma conhecida como razão de Bowen $(\beta)$ e tendo sida amplamente utilizada na estimativa da evapotranspiração (Mastorilli et al., 1989; Fontana et al., 1991; Herbst et al., 1996; Steduto \& Hsiao, 1998).

$$
\beta=\frac{H}{L E}
$$

Após a estimativa da razão de Bowen para cada intervalo de tempo, e de posse dos valores da radiação líquida $(\mathrm{Rn})$ e dos fluxos de calor sensível no solo $\left(\mathrm{G}_{1}\right.$ e $\left.\mathrm{G}_{2}\right)$, obtidos com 
sensores automáticos, foi possível realizar a estimativa do fluxo de calor sensível, H, em MJ.m ${ }^{2} \cdot \mathrm{d}^{-1}$, (equação 7$)$.

$$
\mathrm{H}=\beta . \mathrm{LE}
$$

Conhecidos todos os valores significativos dos componentes do balanço de energia foi possível calcular a estimativa da evapotranspiração do capim tanzânia (ETc), em mm.20min ${ }^{-1}$, para cada intervalo de tempo de 20 minutos, em todo o período estudado.

$$
\mathrm{ETc}=\frac{\mathrm{LE}}{2,45 \cdot 72 \cdot \mathrm{t}}
$$

em que:

$\mathrm{t}=$ intervalo de tempo considerado, ou seja, 20 minutos ;

$72=$ constante utilizada para ajustar a escala de tempo; e

2,45 = constante utilizada para converter o fluxo de calor latente em água evapotranspirada.

Na estimativa de evapotranspiração do capim tanzânia (ETc) consideram-se valores diários conforme recomendação de Heilman \& Brittin (1989), Cellier \& Olioso (1993) e Kustas et al. (1996). Foram também descartadas as estimativas de ETc originários de valores da razão de Bowen entre - 0,7 e - 1,3, conforme Uhland et al. (1996).

Enfatiza-se que, considerou-se como período diurno o compreendido entre 6 e 18 horas. A soma dos totais de evapotranspiração, a cada 20 minutos, ocorridas no período citado, excetuado as condições preconizadas no parágrafo anterior, correspondeu a estimativa da evapotranspiração diária. Ressalta-se, ainda, que semanalmente foram feitas manutenções no sistema razão de Bowen, em conformidade com o recomendado pelo fabricante, por meio de calibrações no higrômetro, limpeza dos termopares de cromo-constantan, das mangueiras 
de sucção, do painel solar e da estrutura de sustentação e troca, quinzenal, dos filtros de papel colocados nos orifícios de sucção.

Na área cultivada com o capim tanzânia foi instalado um lisímetro de pesagem com as seguintes dimensões $0,70 \mathrm{~m}$ de profundidade, 1,50 $\mathrm{m}$ de comprimento e 1,30 $\mathrm{m}$ de largura. A medida direta da evapotranspiração da cultura (ETc lisímetro) foi feita utilizando este equipamento, que ficou apoiado sobre três células de carga e foi conectado a um sistema de coleta e aquisição de dados (Datalogger modelo CR10, fabricado pela Campbell Scientific) programado para realizar leituras a cada segundo e armazenar valores médios em intervalos de 20 minutos.

O índice de área foliar do capim tanzânia foi determinado por meio do equipamento LI 2000 Area Meter fabricado pela empresa Licor, sendo que a coleta de dados foi realizada logo após o pastejo, e 6, 12, 18, 24, 30 e 36 dias pós pastejo.

\subsection{Resultados e Discussão}

A evapotranspiração média de cultura estimada pelo sistema automático de razão de Bowen foi de 4,13 mm.d $\mathrm{d}^{-1}$ e o valor médio mensurado pelo lisímetro foi de 4,34 mm.d $\mathrm{d}^{-1}$, para o período entre 21 de junho de 2000 e 15 de julho de 2001. Porém foram identificadas oscilações sazonais, influenciadas pelas condições atmosféricas e pelo desenvolvimento vegetativo da cultura. Na Tabela 1, são apresentados os valores médios diários de ETc para cada ciclo, obtidos com o sistema automático de razão de Bowen (SARB) e os determinados com o lisímetro de pesagem.

Nota-se que, nos ciclos 9 e 10 o SARB superestimou a ETc em relação ao lisímetro de pesagem. Considerando o período completo dos ciclo 9 e 10 a superestimativa foi de 3,7 e $1,6 \%$, respectivamente. Este fato pode ser explicado, pelo efeito advectivo, pois essa superestimativa ocorreu em meses, que se caracterizaram pela baixa de precipitação. Com a baixa umidade relativa e com ocorrência de ventos médios e fortes, o SARB ficou muito 
suscetível a uma contribuição advectiva, pois este equipamento considera apenas elementos micrometeorológicos na estimativa da evapotranspiração.

Tabela 1. Valores médios diários de ETc para cada ciclo, obtidos com o lisímetro de pesagem e com o sistema automático de razão de Bowen (SARB), em Piracicaba, SP.

\begin{tabular}{cccc}
\hline Ciclos & Período & \multicolumn{2}{c}{ Valores de ETc $\left(\mathbf{m m}^{-1} \mathbf{d}^{\mathbf{1}}\right)$} \\
& & SARB & Lisímetro \\
\hline 1 & $21 / 07 / 00-25 / 08 / 00$ & 3,38 & 3,57 \\
2 & $26 / 08 / 00-30 / 09 / 00$ & 3,85 & 3,90 \\
3 & $01 / 10 / 00-05 / 11 / 00$ & 4,81 & 5,05 \\
4 & $06 / 11 / 00-11 / 12 / 00$ & 4,74 & 5,07 \\
5 & $12 / 12 / 00-16 / 01 / 01$ & 4,82 & 5,35 \\
6 & $17 / 01 / 01-21 / 02 / 01$ & 4,80 & 5,41 \\
7 & $22 / 02 / 01-29 / 03 / 01$ & 4,74 & 4,95 \\
8 & $30 / 03 / 01-04 / 05 / 01$ & 3,84 & 3,93 \\
9 & $05 / 05 / 01-09 / 06 / 01$ & 3,26 & 3,14 \\
10 & $10 / 06 / 01-15 / 07 / 01$ & 3,10 & 3,06 \\
\hline
\end{tabular}

Podemos notar que, nos ciclos 1, 2, 3, 4, 5, 6, 7, e 8 os valores de ETc determinados pelo lisímetro foram superiores aos valores obtidos pelo SARB. Esta superioridade considerando os dados completos de cada ciclo foi de 6,$4 ; 1,4 ; 5,3 ; 7,4 ; 11,9 ; 13,8 ; 5,0$ e 2,6\%, respectivamente. Nos ciclos 3 e 7, ocorreu uma pequena subestimativa de 1,4 e 2,6\%, respectivamente, em relação a ETc determinada pelo lisímetro, indicando que a contribuição advectiva e o efeito da chuva não interferiram significativamente nas medidas obtidas pelo SARB.

A Figura 1(a) mostra a representação gráfica da evapotranspiração do capim tanzânia medida pelo lisímetro de pesagem (ETc lisímetro) e estimada pelo sistema automático de razão de Bowen (ETc Bowen), entre os dias 10 de junho de 2001 (dia juliano 161) e 15 de 
julho de 2001 (dia juliano 196), ou seja, intervalo entre os dois pastejos correspondentes ao ciclo 10. Verifica-se que a estimativa da evapotranspiração do capim tanzânia obtida pelo SARB, em quase todo período analisado, superestimou a medida da evapotranspiração obtida pelo lisímetro de pesagem. Este fato se deve à contribuição advectiva da área externa ao pivô-central, pois os dados foram obtidos em um período com baixa ocorrência de precipitação, ventos fortes e com o ar atmosférico apresentando níveis baixos de umidade. Apesar da ETc Bowen ter sido influenciado pela advecção, houve uma boa correlação entre os valores medidos pelo lisímetros e os estimados pelo SARB. Esta correlação mostra que a contribuição advectiva neste período, apresentou uma relativa homogeneidade, ou que a suscetibilidade do equipamento à essa contribuição se dá com uma sensibilidade que o seu reflita em um efeito relativamente homogêneo (Figura 2(a)).

A Figura 1(b) mostra a representação gráfica da evapotranspiração do capim tanzânia medida pelo lisímetro de pesagem (ETc lisímetro) e estimada pelo sistema automático de razão de Bowen (ETc Bowen), entre os dias 22 de fevereiro de 2001 (Dia juliano 17) e 29 de março de 2001 (Dia juliano 88), ou seja, intervalo entre os dois pastejos correspondente ao ciclo 6. Verifica-se que a estimativa da evapotranspiração do capim tanzânia obtida pelo SARB, em quase todo período analisado, subestimou a medida da evapotranspiração obtida pelo lisímetro de pesagem; esta subestimativa é devida a ausência de gradiente de pressão de vapor em alguns dias, pois este ciclo foi caracterizado por apresentar a maior ocorrência de dias com chuva verificada em todo o período analisado. O efeito da exposição do SARB em dias chuvosos também pode ser evidenciado pala baixa correlação entre o equipamento e o lisímetro (Figura 2(b)).

A baixa correlação obtida entre os dados medidos pelo lisímetro e estimados pelo SARB, para o ciclo 6, diferiu dos valores encontrados por Azevedo (1999) e Silva (2000), para Piracicaba, SP. Entretanto, os trabalhos realizados por estes autores foram realizados em períodos de baixa ocorrência de precipitação o que implica, em observações em condições distintas das que ocorreram neste experimento.

O efeito da ocorrência de chuva pode ser evidenciado também durante o ciclo 6, pois 
neste período choveu $251,3 \mathrm{~mm}$. Este ciclo, também se caracterizou por apresentar, baixa troca de massa de ar em decorrência de baixos valores médios de velocidade do vento, e como consequiência da baixa velocidade houve um pequeno transporte de energia diminuindo o efeito da contribuição advectiva.
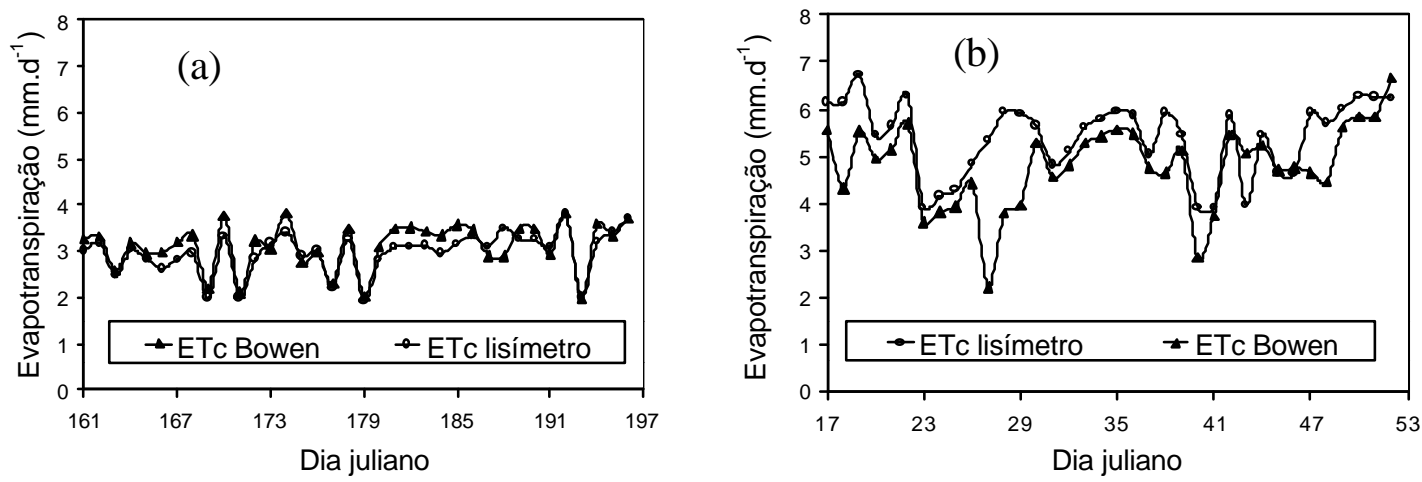

Figura 1 - Evapotranspiração obtida pelo lisímetro e pelo sistema automático de razão de Bowen para (a) ciclo 10 e (b) ciclo 6, em Piracicaba, SP.
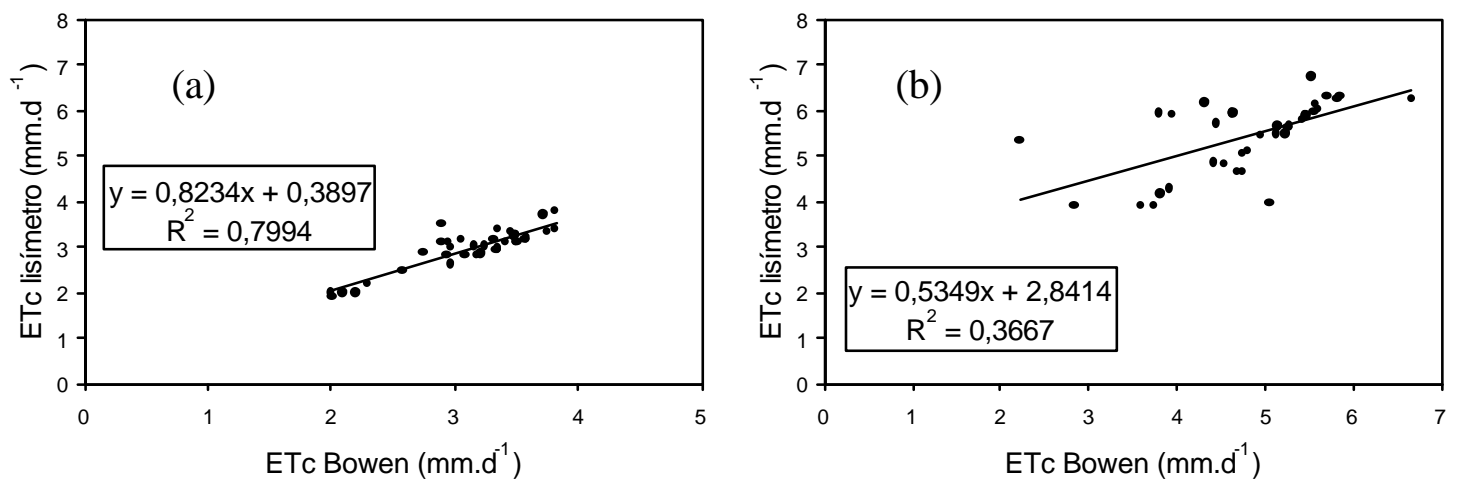

Figura 2 - Relação entre a evapotranspiração obtida pelo lisímetro e pelo sistema automático de razão de Bowen e para (a) ciclo 10 e (b) ciclo 6, em Piracicaba, SP.

A Figura 3(a) mostra a variação do índice de área foliar (IAF) no ciclo 10 e a figura 3(b) no ciclo 6. Pode-se notar que, o IAF inicial correspondente a um resíduo após o pastejo 
de 0,40 m de altura para o capim tanzânia é de 0,15 , este valor baixo se deve à distribuição em touceiras do capim sobre a superfície do solo. O índice de área foliar máximo no ciclo 10 foi de 3,5, e no ciclo 6 foi de 7,3, caracterizando a estacionalidade de produção do capim na região de Piracicaba, SP.
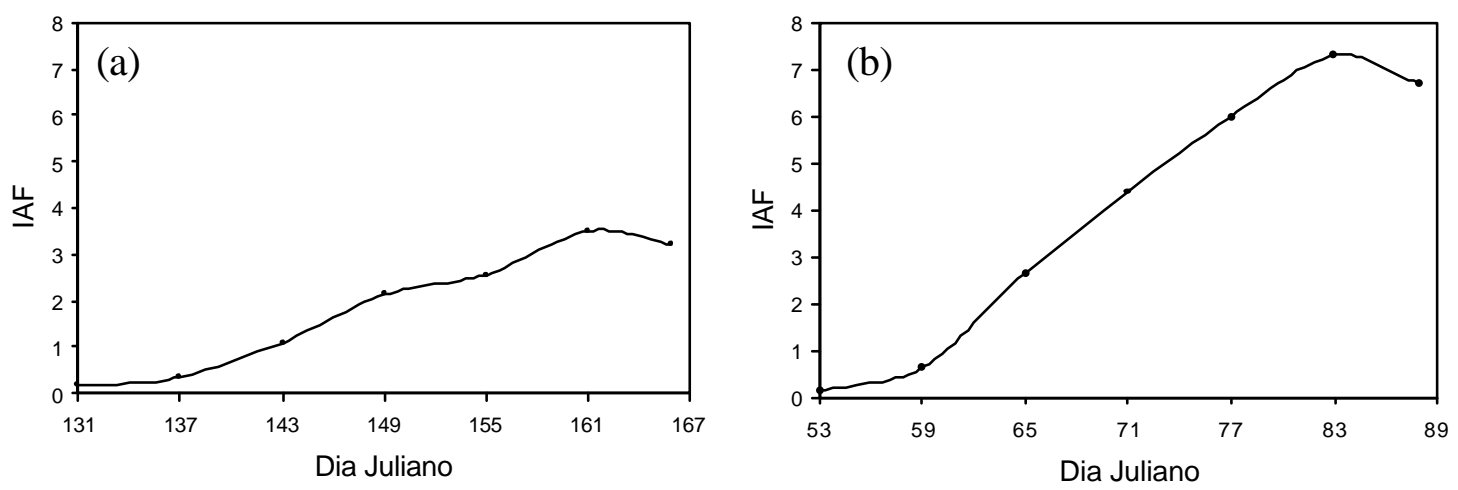

Figura 3 - Índice de área foliar (IAF) do capim tanzânia: (a) no ciclo 10 e (b) no ciclo 6, em Piracicaba, SP.

\subsection{Conclusões}

A estimativa da evapotranspiração, obtida pelo sistema automático de razão de Bowen, pode ser influenciada pela contribuição advectiva, provinda de áreas secas não irrigadas circunvizinhas à área irrigada, principalmente em regiões de clima seco e com ventos fortes. Devem-se observar as alturas dos braços do equipamento, onde estão os sensores que permitem as determinações de temperatura do ar e umidade absoluta, bem como o tamanho da área tampão.

A utilização de métodos de estimativa da evapotranspiração, que utilizam variáveis ambientais com aquisição automática de dados em tempo real, como o método da razão de Bowen, somente apresentarão bons resultados em relação a dispositivos lisimétricos, se forem consideradas as contribuições das áreas vizinhas. 


\section{CONCLUSÕES GERAIS}

Com base nas informações coletadas e analisadas no presente trabalho foram estabelecidas as seguintes conclusões.

A utilização de sistemas automáticos da razão de Bowen para a estimativa da evapotranspiração, pode prover resultados satisfatórios desde que se observem os seguintes detalhes:

a) a estimativa da evapotranspiração, obtida pelo sistema automático de razão de Bowen, pode ser influenciada pela contribuição advectiva, provinda de áreas secas não irrigadas circunvizinhas à área irrigada, principalmente em regiões de clima seco e com ventos fortes;

b) deve-se observar as alturas dos braços do equipamento, onde estão os sensores que permitem as determinações de temperatura do ar e umidade absoluta, bem como o tamanho da área tampão;

c) a ocorrência de chuvas de longa duração, pode subestimar a evapotranspiração em relação ao lisímetro, devido a ausência de gradientes de temperatura do ar e umidade absoluta; e

d) não se deve utilizar períodos de integração menores que 20 minutos nas estimativas de evapotranspiração.

Os sistemas automáticos de razão de Bowen apresentaram pequena necessidade de manutenção, porém esta apresenta um certo grau de complexibilidade.

O lisímetro é um equipamento eficiente para a determinação da evapotranspiração. Entretanto períodos de integração de 20 e 60 minutos devem ser evitados em estudos sobre a 
variação da evapotranspiração diária, pois a ação dos ventos que chocam com a superfície vegetada do equipamento podem influenciar na qualidade dos dados.

A evapotranspiração média do capim tanzânia foi de $4,13 \mathrm{~mm} \cdot \mathrm{d}^{-1}$, segundo o balanço de energia e 4,34 mm.d $\mathrm{d}^{-1}$, obtido pelo lisímetro de pesagem, em Piracicaba, SP.

O estabelecimento das relações apresentadas neste trabalho, mostra que o saldo de radiação em superfície gramada, assim como sobre o capim tanzânia, pode ser estimado satisfatoriamente a partir da irradiância solar global, porém há a necessidade de se considerar suas variações sazonais.

A radiação líquida da superfície vegetada com capim tanzânia foi superior à radiação líquida disponível para um superfície gramada. A relação entre Rn e Qg sobre a superfície vegetada com capim tanzânia cresceu com o aumento do índice de área foliar.

Regressões entre radiação líquida e a irradiância solar global para as duas superfícies vegetadas são apresentadas, $\mathrm{Rn}=0,5418 . \mathrm{Qg}\left(\mathrm{r}^{2}=0,9297\right)$ para uma superfície gramada e $\mathrm{Rn}=0,5613 . \mathrm{Qg}\left(\mathrm{r}^{2}=0,8719\right)$ para uma superfície vegetada com o capim tanzânia, em Piracicaba, SP. 


\section{REFERÊNCIAS BIBLIOGRÁFICAS}

ABOUKHALED, A.; ALFARO, A.; SMITH, M. Lysimeters. Rome: FAO, 1982. 68p. (FAO, Irrigation and Drainage Paper, 39).

ALLEN, R.G.; HILL, RW.; SRIKANTH, V. Evapotranspiration parameters for variablysized wetlands. Transactions of the ASAE, v.37, p.9, 1994.

ALLEN, R.G., PEREIRA, L.S., RAES, D., Crop evapotranspiration - Guidelines for computing crop water requeriments. Rome: FAO, 1998. 75p. (FAO, Irrigation and Drainage Paper, 56).

ALVIM, M.J. Produção de gramíneas tropicais e temperadas, irrigadas na época da seca. Revista da Sociedade Brasileira de Zootecnia. v.15, n.5, 1986.

ANGUS, D.E.; WATTS, P.J. Evapotranspiration - How good is the Bowen ratio method ? Agricultural Water Manegement, v.8, p.133-150, 1984.

ASHKTORAB, H; PRUITT, W.O.; PAWU, K.T. Partitioning of evapotranspiration using lysimeter and micro-Bowen-ratio system. Journal of Irrigation and Drainage Engineering, v.120, n.2, p.450-464. 1994.

ASHKTORAB, H.; PRUITT, W.O.; PAWU, K.T.; GEORGE, W.V. Energy balance determinations close to the soil surface using a micro-Bowen ratio system. Agricultural and Forest Meteorology. v.46, n.3, p.259-274. 1989.

AZEVEDO, B.M. Evapotranspiração de referência obtida com a razão de Bowen, lisímetro de pesagem e equação de Penman-Monteith utilizando sistemas automáticos. Piracicaba, 1999. 81 p. Tese (Doutorado) - Escola Superior de Agricultura "Luiz de Queiroz", Universidade de São Paulo.

BASELGA, J.J.; ALLEN, R.G. A Penman-Monteith for a semi-arid climate in SouthWestern Spain. Transactions of the ASAE, v.39, p.999-1007, 1996.

BAUSCH, W.C.; BERNARD, T.M. Spatial averaging Bowen ratio system: description and lysimeter comparison. Transactions of the ASAE, v.35, p.121-128, 1992. 
BERGAMASCHI, H.; OMETTO, J.C.; VIEIRA, H.J. Deficiência hídrica em feijoeiro, II Balanço de energia. Pesquisa Agropecuária Brasileira, v.1, n.1, p. 745-757, 1988.

BERLATO, M. A.; MOLION, L. C. B. Evaporação e evapotranspiração. Porto Alegre: IPAGRO, 1981. 95p. ( IPAGRO. Boletim Técnico, 7 ).

BLAD, B.L.; ROSENBERG, N.J. Lysimetric calibration of the Bowen ratio-energy balance method for evapotranspiration estimation in the central great plains. Journal of Applied Meteorology, v.13, p.227-236, 1974.

BLAND, W.L.; LOEW, J.T.; NORMAN, J.M. Evaporation from cranberry. Agricultural and Forest Meteorology, v.81, p.1-12, 1996.

BLANEY, H. F.; CRIDDLE, W. D. Determining water requirements in irrigated areas from climatological and irrigation data. Washington: USDA, 1950. 48p.

BOTREL, M.A. ; ALVIM, M.J. ; XAVIER, D.F. Efeito da irrigação sobre algumas características agronômicas de cultivares de capim-elefante. Pesquisa Agropecuária Brasileira, v.26, n.10, p.1731-1736, 1991.

BOWEN, I. S. The ratio of heat losses by conductions and by evaporation from any water surface. Physical Review Serial v.2, n.27, p.779-787, 1926.

BREMER, D.J.; HAM, J.M. Effect of spring burning on the surface energy balance in a tallgrass prairie. Agricultural and Forest Meteorology, v.97, n.1, p.43-54, 1999.

BRUTSAERT, W. Evaporation into the atmosfere: theory, history and applications. Dordrecht: Kluver Academic, 1982. 299p. (Environmental Fluid Mechanics, 1).

BURMAN, R. D. ; NIXON, P. R. ; WRIGTH, J. L. ; PRUIT, W. O. Water requirements. In: JENSEN, M. E., (Ed.). Design and operation of farm irrigation system St. Joseph: ASAE, 1983. cap. 6, p. 189-232.

CAMARGO, A.P. Balanço hídrico no Estado de São Paulo. Campinas: IAC, 1971. 28p. (Boletim técnico, 116). 
CAMPECHE, L. F. S. M. Estimativa da resistencia de dosel (rc) da grama com uso da termometria ao infravermelho. Piracicaba, 1997. 52p. Dissertação (Mestrado) - Escola Superior de Agricultura “Luiz de Queiroz”, Universidade de São Paulo.

CAMPECHE, L. F. S. M. Construção, calibração e analise de desenvolvimento de lisímetro de pesagem para determinação da evapotranspiração da cultura da lima ácida "Tahiti" (Citrus latifolia Tam.). Piracicaba, 2002. 64p. Tese (Doutorado) - Escola Superior de Agricultura “Luiz de Queiroz”, Universidade de São Paulo.

CARGENEL, A.L.; BREVEDAN, R.E.; LUAYZA, G; PALOMO, R. Evapotranspiration measurements over a soybean crop. Transactions of the ASAE, v.39, p.304-308, 1996.

CELLIER, P.; OLIOSO, A. A simple system for automated long-term Bowen ratio measurement. Agricultural and Forest Meteorology, v.66, p.81-92, 1993.

CLOTHIER, B.E.; KERR, J.P.; TALBOT, J.S. Measured and estimated evapotranspiration from weel-watered crops. New Zeland Journal of Agricultural Research, v.25, p.301-307, 1982.

COOPER, J.P. ; TAITON, N.M. Light and temperature requirements for the growth of tropical and temperate grasses. Herbage Abstracts, v.38, p.167-176, 1968.

CORSI, M. Espécies forrageiras para pastagem. Pastagens : fundamentos da exploração racional. 2. ed. Piracicaba: FEALQ,. 1994. 81p.

CRUZ, R.F.R. Comparação do desempenho de dois tipos de lisímetros na determinação da evapotranspiração máxima da cultura da ervilha (Pisum sativum, L.). Piracicaba, 1995. 55p. Dissertação (Mestrado) - Escola Superior de Agricultura "Luiz de Queiroz", Universidade de São Paulo.

CUNHA, R.C.; BERGAMASCHI, H.; BERLATO, M.A.; MATZENAUER, R. Balanço de energia em cultura de milho. Revista Brasileira de Agrometeorologia, v.4, p.1-14, 1996. 
DAAMEN, C.C.; DUGAS, W.A.; PRENDERGAST, P.T.; JUDD, M.J.; MCNAUGHTON, K.G. Energy flux measurements in a sheltered lemon orchard. Agricultural and Forest Meteorology, v.93, n.3, p.171-183, 1999.

DECKER, W.L. Variations in the net exchange of radiation from vegetative of different heights. Journal Geophysic Resource, v.64, p.1617-1619, 1959.

DOORENBOS, J.; PRUITT, J.O. Guidlines for predicting crop water requirements. Rome: FAO, 1977. 179p. (FAO Irrigation and Drainage Paper, 24).

DUGAS,W.A.; FRITSCHEN, L.J.; GAY L.W.; HELD, A.A.; MATTHIAS A.D.; REICOSKY, D.C.; STEDUTO. P.; STEINER, J.L. Bowen ratio, eddy correlation, and portable chamber measurements of sensible and latent heat. Agricultural and Forest Meteorology, v.56, n.12, p.1-20, 1991.

DUNIN, F.X.; NULSEN, R.A.; BAXTER, I.N.; GREENWOOD, E.A.N. Evaporation from a lupin crop: a comparison of methods. Agricultural and Forest Meteorology, v.46, n.4, p.297-311, 1989.

EMPRESA BRASILEIRA DE PESQUISA AGROPECUÁRIA. Centro Nacional de Pesquisa de Solos. Sistema Brasileiro de Classificação de Solos, Rio de Janeiro, 1999. 412p.

FERNANDES, A.L.T. Monitoramento da cultura do crisântemo em estufa através do uso de lisímetro e estação agrometeorológica automatizados. Piracicaba, 1996. 96p. Dissertação (Mestrado) - Escola Superior de Agricultura "Luiz de Queiroz", Universidade de São Paulo.

FOLEGATTI, M.V.; SCATOLINI, M.E.; PAZ, V.P.S. et al. Efeitos da cobertura plástica sobre os elementos meteorológicos e evapotranspiração da cultura do crisântemo em estufa. Revista Brasileira de Agrometeorologia, v.5, n.2, p.155-163, 1997.

FONTANA, D.C.; BERLATO, M.A.; BERGAMASCHI, H. Balanço de energia em soja irrigada e não irrigada. Pesquisa Agropecuária Brasileira, v.3, n.26, p.403-410, 1991. 
FRANGI, J.P.; GARRIGUES, C; HABERSTOCK, F; FOREST, F. Evapotranspiration and stress indicator through Bowen ratio method. Transactions of the ASAE, v.39, p.800805, 1996.

FRIZZONE A. Aplicação de fertilizantes em sistemas de irrigação localizada. In: Fertilizantes. Fluídos Piracicaba: Potafós, 1994. p.78-86.

GHELFI FILHO, H. Efeito da irrigação sobre a produtividade do capim elefante (Pennisetum purpureum Schum.) variedade Napier, 1972. Dissertação (Mestrado) Escola Superior de Agricultura “Luiz de Queiroz”, Universidade de São Paulo.

GHELFI FILHO, H. Efeito da irrigação sobre o capim colorirão (Panicum maximum, Jacq.)

O SOLO, v.68, n.1, 1976.

GOLTZ, S. M.; PRUITT, W.O. Spatial and temporal variations of evapotranspiration downwind from a trailing of a dry fallow field. In . MORGAN, D. L.; PRUITT, W. O.; LOURENCE, F. J. Evaporation from an irrigated turf under advection of dry air at Davis, California. Davis: Univerity of California, 1970. 70p.

GRANT, D.R. Comparision of evaporation measurements using different methods. Quartely Journal of the Royal Meteorological Society, v.101, p.543-550, 1975.

GREEN, A.E.; CLOTHIER, B.E.; KERR, J.P.; SCOTTER, D.R. Evapotranspiration from pasture: a comparison of lysimeter and Bowen ratio measurements with Priestley-Taylor estimates. New Zealand Journal of Agricultural Research, v.27, n.3, p.321-327, 1984.

GUTIÉRREZ, M.V.; MEINZER, F.C. Energy balance and latent heat flux partiotining in coffee hedgerows at different stages of canopy development. Agricultural and Forest Meteorology, v.68, p.173-186, 1994.

HARGREAVES, G. H. Water requirements manual for irrigated crop,and rainfed agriculture. Logan: Utah State University, 1977. 41p.

HATFIELD, J. L. Research priorities in ET: evolving methods. Transactions of the ASAE, v.31, n.2, p. 491-495, 1988. 
HEILMAN, J. L.; BRITTIN, C. L. Fetch requerement for Bowen ratio measurement of latent and sensible heat fluxes. Agricultural and Forest Meteorology, v.44, p.261-273, 1989.

HERBST, M; KAPPEN, L; THAMM, F; VANSELOW, R. Simultaneous measurements of transpiration, soil evaporation and total evaporation in a maize field in northern Germany. Journal of Experimental Botany, v.47, p.1957-1962, 1996.

HERRERA J.P. Efecto del regimen del riego sobre o rendimento y la utilizacion del espécies de pastos tropicales. Havana (Cuba). Pastos y Forrajes, v.8, n.2, p.25-47, 1985.

HILLESHEIM, A. Manejo do capim elefante: corte. In: SIMPÓSIO SOBRE MANEJO DA PASTAGEM. Piracicaba, 1994. Anais Piracicaba: FEALQ, 1994. p.231.

HOWELL, T.A.; SCHNEIDER, A.D.; JENSEN, M.E. History of lysimeter desing and use for evapotranspiration. Lysimeter for evapotranspiration and enviroment measurements. New York: ASCE, 1991. p.1-19.

IBANEZ, M.; PEREZ, P.J.; ROSELL, J.I.; CASTELLVI, F. Estimation of the latent heat flux over full canopy covers from the radiative temperature Journal of Applied Meteorolgy, v.38, n.4, p.423-431, 1999.

JARA, J.; STOCKLE, C.O.; KJELGAARD, J. Measurement of evapotranspiration and its components in a corn (Zea Mays L.) field. Agricultural and Forest Meteorology, v.92, p.131-145, 1998.

JENSEN, M.E. Consumptive of water and irrigation water requeriments. New York: ASCE, 1973. 215p.

JENSEN, M. E.; HAISE, H. R. Estimating evapotranspiration from solar radiation. Journal of Irrigation an Drainage Engineering, v. 89, p. 15-41, 1963.

JENSEN, M.E.; BURMAN, R.D.; ALLEN, R.G. Evapotranspiration and irrigation water requeriments. New York: ASCE, 1990. 332p. 
KJELGAARD, J.F.; STOCKLE, C.O.; VILLAR MIR, J.M.; EVANS, R.G.; CAMPBELL, G.S. Evaluating methods to estimate corn evapotranspiration from short-time interval weather data. Transactions of the ASAE, v.37, p.1825-1833, 1994.

KUSTAS, W.P.; STANNARD, D.I.; ALLWINE, K.J. Variability in surface energy flux partiotining during Washita`92: resulting efects on Penaman-Monteith and Priestly-Taylor parameters. Agricultural and Forest Meteorology, v.82, p.171-193, 1996.

LADEIRA, N.P. Estudos sobre produção e irrigação dos capins Pangola, Sempre-verde e Gordura, durante o ano de 1965. Revista Ceres, v.13, n.74, p.105-106, 1966.

LEMON, E. R.; GLASER, A. H.; SATTERWHITE, L. E. Some aspects of the relationship of soil, plant and meteorological factors to evapotranspiration. Soil Science Society of American Proceedings, v.21, n.5, p. 464-468, 1957.

LIRA, R.; OLIVEIRA, F.B. Balanço de energia sobre um canavial na zona da mata alagoana - comparação inverno/verão. In: CONGRESSO BRASILEIRO DE AGrometeorologiA, 10., Piracicaba, 1997. Anais Santa Maria: Sociedade Brasileira de Agrometeorologia. 1997. p. 538-540.

LLOYD, C.R., GASH, J.H.C., SHUTTLEWORTH, W.J., The measurement and modelling of rainfall interception by Amazonian rain forest. Agricultural and Forest Meteorology, v.43, p.277-294, 1988.

LLASAT, M. C.; ZINDER, R. L Data error effects on net radiation and Evapotranspiration estimation. Agricultural and Forest Meteorology. v. 91, p.209-221, 1998.

LUCHIARI JÚNIOR, A. Measurements and predictios of evapotranspiration rates from irrigated wheat in the Cerrado region of central Brazil. Ithaca, 1988. 171p. Tese ( Phd) Cornell University.

LUCHIARI JÚNIOR., A.; RIHA, S. J. Bulk surface resistance and its effect on evapotranspiration rates in irrigated wheat. Agronomy Journal, v.83, p.888-895, 1991. 
MAGGIOTTO, S. R. Estimativa da evapotranspiração de referência pelo uso da termometria ao infravermelho. Piracicaba, 1996. 71p. Dissertação (Mestrado) - Escola Superior de agricultura “Luiz de Queiroz”, Universidade de São Paulo.

MAKI, T. Methods for estimating evapotranspiration under wet and arid field conditions. Japan Agricultural Research Quarterly, v.25, n.3, p.214-221, 1991.

MALEK, E. Rapid changes of the surface soil heat flux and its effects on the estimation of evapotranspiration. Journal of Hydrology, v.142, p.89-97. 1993.

MALEK, E.; BINGHAM, G.E. Comparison of the Bowen ratio-energy balance and the water balance methods for the measurement of evapotranspiration. Journal of Hydrology, v.146, p.209-220. 1993.

MALEK, E., BINGHAM, G.E. Partitioning of radiation and energy balance components in an inhomogeneous desert valley. Journal of Arid Enviroments, v.37, n.2, p.193-207. 1997.

MALEK, E.; BINGHAM, G.E.; MCCURDY, G. Annual mesoscale study of water balance in a Great Basin heterogeneous desert valley. Journal of Hydrology, v.191, p.223-244, 1997.

MANTOVANI, E.C. Desarollo y evaluación de modelos para el manejo del riego: estimación de la evapotranspiración y efectos de la uniformidad de aplicación del riego sobre la producción de los cultivos. Córdoba, 1993. 184p. Tese (Doutorado) - Escola Tecnica Superior de Ingeneros Agronomos.

MARASCHIN, G. E. Manejo de coast-cross- 1 sob pastejo. ln: WORKSHOP SOBRE O POTENCIAL FORRAGEIRO DO GÊNERO CYNODON, Juiz de Fora, 1996. Anais Juiz de Fora: EMBRAPA-CNPGL, 1996. p.93-107.

MASTRORILLI, M.; LOSAVIO, N; SCARASCIA, M.E.V.; KATERJI, N. Comparison of methods of measuring maximum evapotranspiration of a meadow in a Mediterranean climate. Rivista di Agronomia, v.23, n.2, p.202-209. 1989.

MEDEIROS, S.R. Irrigação de pastagens. Tem boi na linha - (Informativo pecuário semanal, 185). São Paulo: Boi \& Companhia, 1997. p.14-18. 
MILLAR, B.D. Effect of local advection on evaporation and plant water status. Australian Journal of Agriculture, v.25, p.97-106, 1964.

MONTEITH, J. L. Evaporation and environment. In: SYMPOSIUM OF THE SOCIETY FOR EXPERIMENTAL BIOLOGY, 19., London, Swansea, 1964. Cambridge: Cambridge University Press, 1965. p. 205-234.

MONTEITH, J.L. Principles of environmental physics. London: Edward Arnold, 1973. $241 \mathrm{p}$.

MONTEITH, J. L. Evaporation from land surfaces: progress in analysis and prediction since 1948. In: NATIONAL CONFERENCE ON ADVANCES IN EVAPOTRANSPIRATION, Chicago, 1985. Proceedings. St. Joseph: ASAE, 1985. p. 4-12.

MOURA, A.L.; MARTINS, D. Comparação da estimativa horária da evapotranspiração através de diferentes métodos. Energia na Agricultura, v.7, n.3, p.4-11, 1992.

MUKAMAL, E. I.; BRUCE, J. P. Evaporation measurements by pan and atmometer. International Union of Geodesy an geophysics. Association od Scientific hydrology, 53: 408-20 apud CHANG, JEN-HU. 1968. Climate and agriculture: an ecological survey. Chicago, Aldine.

NIE, D.; FLITCROFT, I.D.; KANEMASU, E.T. Performance of Bowen ratio systems on a slope. Agricultural and Forest Meteorology, v.59, n.34, p.165-181, 1992.

NORMAN, J. M.; CAMPBELL, G. Application of a plant-environment model to problems in irrigation. In: HILLEL, D. Advances in irrigation. New York: Academic Press, 1983. v. 2, p. 155-188.

OKE, T. R. Boundary layer climates. 2. ed. London: Routledge, 1992. 435p.

OLIVEIRA, G.M.; LEITÃO V.B.R..; CANDIDO.; L.A.; AZEVEDO.P.V.; AMORIM NETO, M.S.; BEZERRA, J.R.C. Uma análise dos componentes do balanço de energia sobre um cultivo de amendoim irrigado. In: CONGRESSO BRASILEIRO DE 
AGROMETEOROLOGIA, 10., Piracicaba, 1997. Anais Santa Maria: Sociedade Brasileira de Agrometeorologia. 1997. p. 535-537.

OMETTO, J.C. Estudo das relações entre radiação solar global, radiação líquida e insolação. Piracicaba: ESALQ/USP, 1968. 64p. Tese (Doutorado) - Escola Superior de Agricultura "Luiz de Queiroz", Universidade de São Paulo.

ORTEGA-FARIAS, S.O.; CUENCA, R.H.; EK, M. Daytime variation of sensible heat flux estimated by the bulk aerodynamic method over a grass canopy. Agricultural and Forest Meteorology, v.81, p.131-143. 1996.

PELTON, W.L.; KING, K.M.; TANNER, C.B. Na evaluating of the Thornthwaite and mean temperature methods for determining potential evapotranspiration. Agronomy Journal, v.52, n.7, p.387-395, 1960.

PENMAN, H. L. Natural evaporation from open water, bare soil and grass. Proceedings Royal Society of London. Serie A, v. 193,p. 120-145, 1948.

PENMAN, H. L. Evaporation: Introduction survey. Netherlands Journal of Agricultural Science, v.4, n. 1, p.9- 29, 1956.

PEREIRA, R.M.A. Competição de dez gramíneas para capineira, no Cerrado. Revista Ceres, v.13, n.74, p.141-153, 1966.

PEREIRA, A.R. Introdução à Micrometeorologia. Piracicaba, SP: ESALQ, Departamento de Física e Meteorologia, 1998. 70p.

PEREIRA, A.R.; VILLA NOVA, N.A.; SEDIYAMA, G.C. Evapo(transpi)ração. Piracicaba, SP: FEALQ, 1997. 183 p.

PEREZ J., Influencia de la norma y sequencia del riego sobre el rendimento y la calidad en cuatro gramineas. Pastos y forrajes, v.9, n.3, p.231, 1986.

PEREZ, P.J.; CASTELLVI, F.; IBAÑEZ, M.; ROSELL, J.I. Assessment of reliability of Bowen raui method for partitioning fluxes. Agricultural and Forest Meteorology, v.97, p.141-150, 1999. 
PETERSCMITT, J.M.; KATERJI, N. Comparison of different methods for measuring evapotranspiration in non-irrigated wheat. Agronomie, v.9, n.2, p.197-205, 1989.

PRIESTLEY,C. H. B.; TAYLOR, R. J. On the assessment of surface heat flux and evaporation using large-scale parameters. Monthly Weather Review, v.100, p.81-82, 1972.

PRUEGER J.H.; HATFIELD J.L.; AASE J.K.; PIKUL JUNIOR J.L. Bowen-ratio comparisons with lysimeter evapotranspiration. Agronomy Journal, v.89, n.5, p.730736, 1997.

PRUITT, W.O.; ANGUS, D.E. Large weighing lysimeter for measuring evapotranspiration. Transactions of the ASAE, v.3, n.2., p.13-15, 1960.

PRUITT, W.O.; LAURENCE, F.J.; VON OETTINGEM, S. Water use by crops as affected by climate and plant factors. California Agriculture, v.26, p.10-14, 1972.

REICHARDT, K. A água na produção agrícola. Piracicaba: McGraw-Hill de Brasil, 1978, $119 p$.

RESCHKE, G.A.; COSTA, J.M.N.; PRATES, J.E.; SEDIYAMA, G.C.; ROCHA., H.R. Razão de Bowen em áreas de pastagem e de floresta em Ji-Paraná, RO. In: CONGRESSO BRASILEIRO DE AGROMETEOROLOGIA, 10., Piracicaba, 1997. Anais Santa Maria: Sociedade Brasileira de Agrometeorologia, 1997. p.547-548.

RITCHIE, J.T.; BURNET, E. A precision weighing lysimeter for row crop use studies. Agronomy Journal, v.60, p.545-549, 1968.

RODRIGUES, L.R. de A. ; RODRIGUES, T.J.D. Ecofisiologia de plantas forrageiras. ln: ECOFISIOLOGIA DA PRODUÇÃO AGRÍCOLA. Piracicaba: Potafós, 1987. p.203230.

ROLIM, A.F. Sazonalidade de produção de forrageiras. Pastagens: Fundamentos da Exploração Racional Sazonalidade de produção de forrageiras. Piracicaba: FEALQ, 1994.

ROSENBERG, N.J., Microlimate: The biological enviroment. New York: John Wiley, 1983. 315p. 
ROSSET, M.; RIEDO, M.; GRUB, A.; GEISSMANN, M.; FUHRER, J. Seasonal variation in radiation and energy balances of permanent pastures at different altitudes. Agricultural and Forest Meteorology, v. 86, p.245-258, 1997.

SAUER, T.J.; HATFIELD, J.L.; PRUEGER, J.H.; NORMAN, J.M. Surface energy balance of a corn residue-covered field. Agricultural and Forest Meteorology, v.89, p.155$168,1998$.

SCHÖFFEL, E.R., VOLPE, C.A. Parâmetros para a estimativa do saldo de radiação em superfície gramada em Jaboticabal, SP. (Compact disk). In: REUNIÓN ARGENTINA DE AGROMETEOROLOGÍA, 8., Mendoza, Argentina, 2000. Mendonza, 2000.

SENTELHAS, P. C. Estimativa diária da evapotranspiração de referência com dados de estação meteorológica convencional e automática. Piracicaba, 1998. 97p. Tese (Doutorado) - Escola Superior de Agricultura "Luiz de Queiroz", Universidade de São Paulo.

SENTELHAS, P. C.; NASCIMENTO, A.L.C. Saldo de radiação e sua irradiância solar global, em Piracicaba - SP. CONGRESSO BRASILEIRO DE AGROMETEOROLOGIA, 12., E REUNIÃO LATINO-AMERICANA DE AGROMETEOROLOGIA, 3.,: ÁGUA E AGROMETEOROLOGIA NO NOVO MILÊNIO. Fortaleza, 2001. Anais Santa Maria: Sociedade Brasileira da Agrometeorologia, 2001, v.1, p.255.

SHAW, R.H. A comparison of solar radiation and net radiation. Bulletim American Meteorology Society, v.37, p.205-206. 1956.

SILVA, F.C. Determinação da evapotranspiração utilizando o método do balanço de energia e lisímetro de pesagem. Piracicaba, 2000. 72 p. Tese (Doutorado) - Escola Superior de Agricultura "Luiz de Queiroz”, Universidade de São Paulo.

SILVA, L. D. B.; FOLEGATTI, M.V. Determinação da evapotranspiração do capim tanzânia, utilizando um sistema automático de razão de Bowen e um lisímetro de pesagem. CONGRESSO BRASILEIRO DE AGROMETEOROLOGIA, 12., E REUNIÃO LATINO-AMERICANA DE AGROMETEOROLOGIA, 3.,: ÁGUA E 
AGROMETEOROLOGIA NO NOVO MILÊNIO. Fortaleza, 2001. Anais Santa Maria: Sociedade Brasileira da Agrometeorologia, 2001, v.2, p.923.

SILVA, F.C.; FOLEGATTI, M.V.; MAGGIOTTO, S.R. Análise do funcionamento de um lisímetro de pesagem com célula de carga. Revista Brasileira de Agrometeorologia, v.7, n.1, p.53-58, 1999.

SILVA, F.C.; FOLEGATTI, M.V.; PEREIRA, A.R.; VILA NOVA, N.A. Uso de dispositivos lisimétricos para medida da evapotranspiração de referência. Revista Brasileira de Agrometeorologia, v.7, n.1, p.19-23, 1999.

SINCLAIR, T.R.; ALLEN, JUNIOR. L.H.; LEMON, E. R. An analysis of error in the calculation of energy flux densisties above vegetation by Bowen ratio profile method. Boundary-Layer Meteorology, v. 8, p. 129-139. 1975.

SMITH, M., (Ed.). Report on the expert consultation on procedures for revision of FAO guidelines for predictions of crop water requirements. Rome: FAO, 1991. $45 \mathrm{p}$.

SOUZA, J. L.; ESCOBEDO, J. F. Balanço de radiação em cultivos de feijão- vagem com e sem cobertura de polietileno. Pesquisa Agropecuária Brasileira. v. 32, n. 1, p. 1-15, 1997.

STANHILL, G. A comparasion of methods of calculatiing potential evapotranspiration from climatic data. Israel Journal Agriculture Resource, v.11, p. 159-171, 1961.

STEDUTO, P.; HSIAO, T.C. Maize canopies under two soil water regimes. IV. Validity of Bowen ratio-energy balance technique for measuring water vapor and carbon dioxide fluxes at 5-min intervals. Agricultural and Forest Meteorology, v.89, p.215228,1998 .

TAFUR, H. Efectos de la interacion riego-fertilizacion sobre la produccion de forraje en tres pastos de corte. Palmira (Colombia) Acta Agronomica, v .40, n.12, p.54, 1990.

TANNER, C.B. Energy balance approach to evapotranspiration from crops. Soil Science Society of America. Proceedings. v. 24, n.1, p.1-9. 1960. 
TANNER, C. B.; LEMON, E. R. Radiant energy utilized in evapotranspiration. Agronomy Journal, v. 54, n.3, p. 207-212, 1962.

TANNER, B.D.; GREENE, J.P.; BINGHAM, G.E. A Bowen-raio design for long term measurements. Transactions of the ASAE, v.2, n.4, p.1-6, 1987.

THOM, A. S. Momentum, mass and heat exchange of plant communities. In: MONTEITH, J. L., (Ed.). Vegetation and the atmosphere. London: Academic Press, 1975. v. 1, cap. 3, p. $57-109$.

THOM, A. S.; OLIVER, H. R. On Penman's equation for estimating regional evaporation. Quartely Journal of the Royal Meteorological Society, v. 103, p.345-357, 1977.

THORNTWAITE, G.W. An approach toward a rational classification of climate. Geographycal Review, v.38, n.1, p.55-94. 1948.

UHLAND, H.E.; HOUSER, P.R.; SHUTTLEWORTH, W.J.; YANG, Z.L. Surface flux measurement and modelling at a semi-arid Sonoran Desert site. Agricultural and Forest Meteorology, v.82, p.119-153. 1996.

VILLA NOVA, N.A. Estudos sobre o balanço de energia em cultura de arroz. Piracicaba, SP, 1973. 78 p. Tese (Livre docência) - Escola Superior de Agricultura "Luiz de Queiroz", Universidade de São Paulo.

VILLA NOVA, N. A. Principais métodos de estimativa de aplicação de água de irrigação. Piracicaba: ESALQ, Departamento de Física e Meteorologia, 1987. 22p.

VILLA NOVA, N. A.; REICHARDT, K. Evaporação e evapotranspiração. In: RAMOS, F.; OCCHIPINTI, A.G.; VILLA NOVA, N.A.; REICHARDT, K.; MAGALHÃES, P.C.; CLEARY, R.W. Engenharia Hidrológica, Rio de Janeiro: ABRH, 1989. cap.3, p. 145-197. (Coleção ABRH de Recursos Hídricos, 2).

VILLA NOVA , N. A.; SALATI, E.; MATSUI, E. Estimativa da evapotranspiração na Bacia Amazônica. Acta Amazonica, v. 6, n. 2, p. 215-258, 1976. 